\title{
Geology of the
}

\section{Bernal-Jalpan Area}

\section{Estado de Querétaro}

\section{Mexico}

By KENNETH SEGERSTROM

GEOLOGIC INVESTIGATIONS IN MEXICO

GEOLOGICAL S URVEY B ULLETIN $1104-\mathrm{B}$

Preparedin cooperation with the Instituto Nacional para la Investigación de Recursos Minerales, under the auspices of the International Cooperation Administration of the Department of State

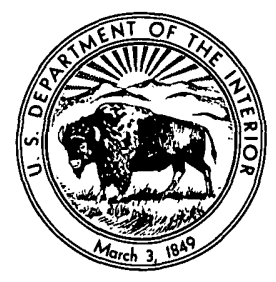




\section{UNITED STATES DEPARTMENT OF THE INTERIOR}

STEWART L. UDALL, Secretary

\section{GEOLOGICAL SURVEY}

Thomas B. Nolan, Director

For sale by the Superintendent of Documents, U.S. Government Printing Office Washington 25, D.C. 


\section{CONTENTS}

$\begin{array}{lr}\text { Page } \\ \text { Abstract } & 19\end{array}$

Introduction

Location _. .

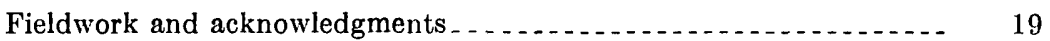

Geography . . .

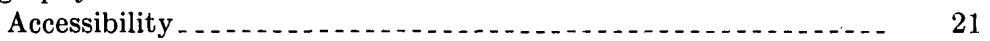

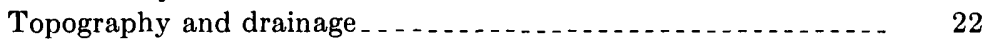

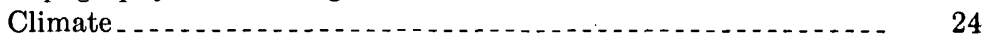

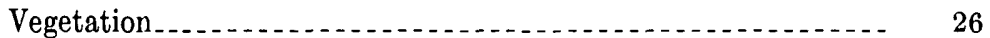

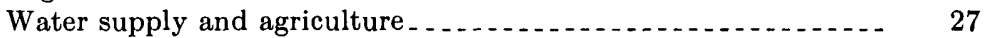

Archeology _. . . . .

Sedimentary, metamorphic, and volcanic rocks $\ldots \ldots \ldots 29$

Jurassic system or older

Pre-Las Trancas rocks.

Jurassic system _...

Las Trancas formation . . 30

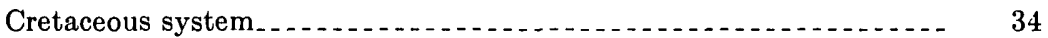

El Doctor limestone. . .

Soyatal and Mexcala formations, undifferentiated . . . . . . . 40

Tertiary system ........ 43

El Morro fanglomerate.

Undifferentiated volcanic rocks...... 44

Late basalt _._._.

Tertiary and Quaternary systems

Clastic deposits of late Cenozoic age

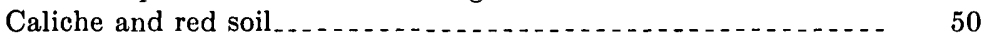

Travertine

Intrusive rocks._.

Porphyritic intrusive rocks

Equigranular intrusive rocks _._.

Contact metamorphic rocks.

Structure

Folds _.

Boudinage..... 62

Fracture cleavage

Thrust faults

Normal faults_._.

Joints_ _ _

Geomorphology

Karst features. $\ldots \ldots \ldots$

Lapies. . . 70

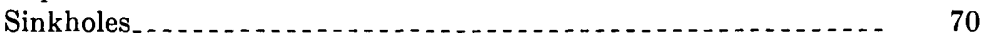

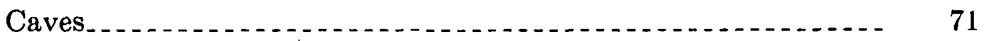

Underground stream channels........... 71 
Geomorphology-Continued Page

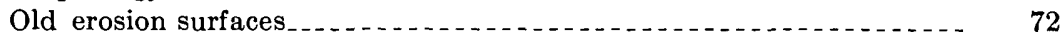

Drainage development. . . .

Erosion forms. . . . . . . . .

Geologic history

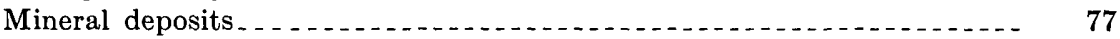

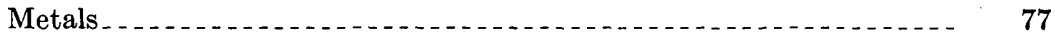

Mining activity and production $\quad 77$

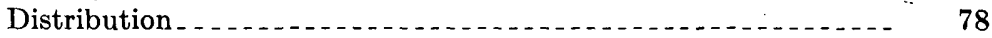

Ore mineralogy and host rock ......... 79

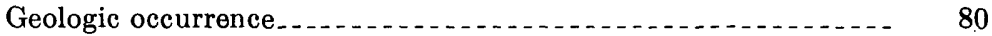

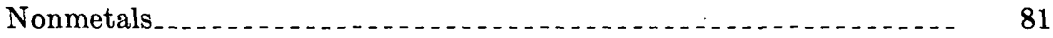

References

Index

\section{ILLUSTRATIONS}

Plate 2. Reconnaissance geologic map and section of the Bernal-Jalpan

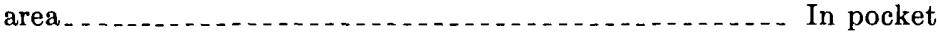

Page

Figure 11. Index map of Mexico .

12. View southwestward up the Río Moctezuma............. 23

13. Canyon of the Río Extorax between Bucareli and Las Medias. $\quad 25$

14. Steeply dipping beds of the Las Trancas formation . . . . . . 33

15. Typical erosional surface of the Las Trancas formation

16. Lens-shaped chert concretions on a weathered surface of the El Doctor limestone. . . . . . . . . 37

17. Nearly vertical bed of El Doctor limestone . . . . . . . . . . 38

18. Contact of the Las Trancas formation and the El Doctor

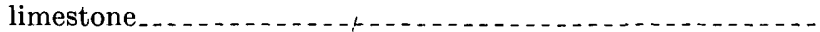

19. Orbicular weathering of rhyolite lava . .

20. Bouldery terrace deposit lying against phyllitic shale of the

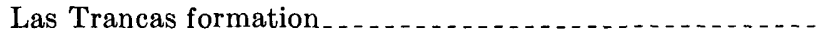

21. Travertine deposit along the canyon of the Río Extórax....

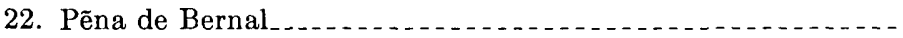

23. General aspect of weathered rhyolite

24. Tight chevron fold in the Las Trancas formation .........

25. Chevron folds in the El Doctor limestone...............

26. Small fold on a limb of the San Lorenzo syncline..........

27. Boudinage and chevron folds in the El Doctor limestone....

28. Isolated, spindle-shaped mass of limestone . . . . . . . . . . .

29. Fracture cleavage dipping steeply toward the right and cutting bedding in the Mexcala formation.............

30. Small folds with sheared limbs in the Las Trancas formation -

31. Crumpled argillaceous limestone and calcareous phyllite beds of the Las Trancas formation. . . . . . . . . . . . .

32. Bedding and fracture cleavage in the Las Trancas formation.

33. The Divisadero escarpment at the edge of the Vizarron erosion

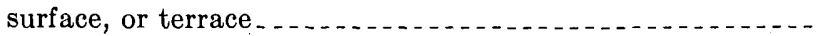

34. The Pẽna Blanca erosion surface . . . . . . . . . . . . . . 


\title{
GEOLOGIC INVESTIGATIONS IN MEXICO
}

\section{GEOLOGY OF THE BERNAL-JALPAN AREA, ESTADO DE QUERÉTARO, MEXICO}

\author{
By Kenneth Segerstrom
}

\begin{abstract}
The area of this report extends from Bernal northeastward to Jalpan, a distance of about $75 \mathrm{~km}$, and lies mostly in the rugged and relatively inaccessible Sierra Madre Oriental, just east of the Mexican Highland. Plateau rocks along the west edge of the Bernal-Jalpan area consist of flat-lying flows, tuffs, and basin-fill clastic deposits of Cenozoic age. Rocks of the Sierra Madre Oriental, which are exposed throughout most of the rest of the area, consist of complexly folded marine sedimentary rocks of Mesozoic age. A thick limestone bank just south of the area and another along the east side are prominent features of the topography and contain rocks of Early Cretaceous (AlbianCenomanian) age. Two stocks, one of diorite and the other of quartz diorite, intrude the sedimentary rocks in the north-central part of the area.

Ore deposits, chiefly lead, zinc, and antimony, but also gold and silver, are widely distributed between Bernal and Jalpan. The chief mining districts are Pinal de Amoles and Río Blanco, which lie along a poorly defined belt of metalliferous mineral deposits extending from Xichú, Guanajuato, southeastward across the States of Querétaro and Hidalgo to Teziutlán, Puebla.
\end{abstract}

\section{INTRODUCTION}

\section{LOCATION}

The Bernal-Jalpan area, approximately 2,250 square $\mathrm{km}$, is 160 $200 \mathrm{~km}$ north-northwest of Mexico City, between lat $20^{\circ} 41^{\prime}$ and $21^{\circ} 15^{\prime} \mathrm{N}$. and between long $99^{\circ} 20^{\prime}$ and $100^{\circ} 00^{\prime} \mathrm{W}$. The area is the north-central part of Querétaro, the fifth smallest of the Mexican States (fig. 11). The capital of the State, also named Querétaro, is about $50 \mathrm{~km}$ west-southwest of Bernal.

\section{FIELDWORK AND ACKNOWLEDGMENTS}

The geology of the area was mapped by the author during 1952 and 1953 on oblique aerial photographs of the U.S. Air Force and on parts of several sheets of the Mexican Army's 1:100,000 map 


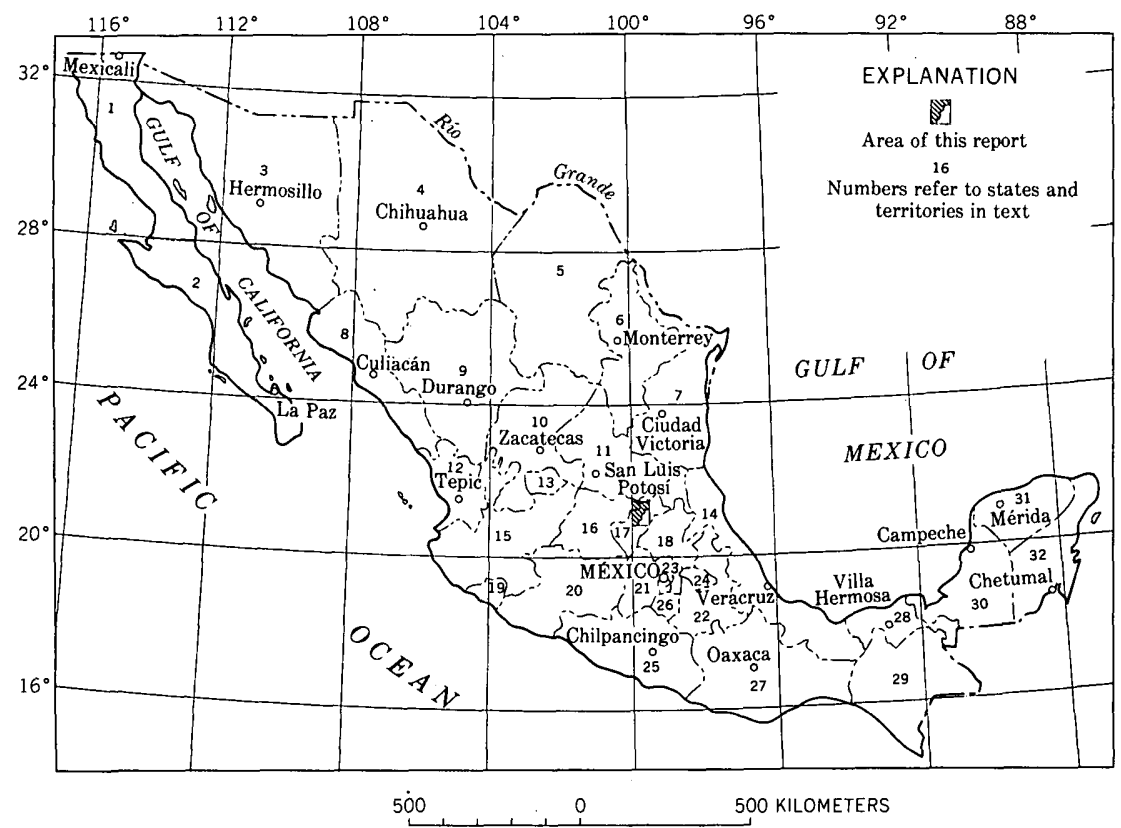

FIGURE 11.--Index map of Mexico showing location of Bernal-Jalpan area.

\section{States and Territories}

1. Baja California Norte
2. Baja California Sur
3. Sonora
4. Chihuahua
5. Coahuila
6. Nuevo León
7. Tamaulipas
8. Sinaloa
9. Durango
10. Zacatecas
11. San Luis Potosí
12. Nayarit
13. Aguascalientes
14. Veracruz
15. Jalisco
16. Guanajuato
17. Querétaro
18. Hidalgo
19. Colima
20. Michoacán
21. México
22. Puebla
23. Distrito Federal
24. Tlaxcala
25. Guerrero
26. Morelos
27. Oaxaca
28. Tabasco
29. Chiapas
30. Campeche
31. Yucatán
32. Territorio de Quintana Roo

series (pl. 2). A few geologic observations of part of the area and a detailed study of the Soyatal mining district. (White, 1948) had been made previously.

The present report is the result of approximately 5 months of fieldwork, much of it in areas very difficult of access. Because of the poor exposures in the western part of the region, the complexities resulting from repeated folding of marine strata in the eastern part, and the general reconnaissance nature of mapping at a $1: 100,000$ scale, not enough information was obtained to construct detailed columnar sections or stratigraphic diagrams. Inasmuch as the geologic map is on a planimetric base, the great relief which characterizes most of the terrain is not shown; interpretation of the map should be made with this omission in mind. 
Work in the Bernal-Jalpan area was initiated through the point 4 program of technical cooperation between the governments of the United States and of Mexico and completed under the auspices of the International Cooperation Administration of the U.S. Department of State. The aid of A. J. Bodenlos, Carl Fries, Jr., and B. W. Wilson of the U.S. Geological Survey and W. E. Humphrey of DeGolyer and MacNaughton, Inc., consultants to Petróleos Mexicanos, is gratefully acknowledged. Jesús Martínez Portillo, librarian of the Instituto de Geología de México, procured most of the bibliographical material used by the author. Rafael Alejandri R. and Edgardo Meave T., of the Instituto Nacional para la Investigación de Recursos Minerales, accompanied the author in the field for several periods of 3 to 7 days and found some of the fossils that were used to determine the age of the Las Trancas formation. Alejandri later mapped areas to the north and south of the area described in the present report, and Meave collaborated with Wilson and with Pedro Hernández, of Recursos Minerales, in mapping the El Doctor area to the southeast. Contiguous areas to the north were mapped by L. Jiménez-López, H. von Kuegelgen, M. Carbonel, and E. Almanza, under the direction of Alejandri.

\section{GEOGRAPHY}

\section{ACCESSIBILITY}

A good hard-surfaced road leads from the city of Querétaro to Bernal, but all other roads of the area are unimproved and are traversible only at average speeds of not over $15-20 \mathrm{~km}$ per hour. A single road marked by many chuck holes, steep grades, and sharp curves, and passable only by jeeps, trucks, and small busses, extends from Bernal to Jalpan. This road, paved in part with cobble stones, was completed in 1910; considering the date and the difficulty of the terrain, building it was a remarkable engineering feat. In 45 years some improvements have been made between Bernal and Pinal de Amoles, but little has been done to improve the stretch between Pinal de Amoles and Jalpan, although indispensable repairs are made after heavy rains. At San Lorenzo, where the Río Extórax is crossed, the road is occasionally closed by high water for days at a time, particularly in September. North of San Lorenzo, the road follows the floor of Arroyo del Pilón for several kilometers. The arroyo carries only a trickle of water during most of the year, but flash floods make crossing somewhat precarious during summer and early fall.

From Bernal to Jalpan, an airline distance of $75 \mathrm{~km}$, the road is $175 \mathrm{~km}$ long and can be traveled in about 10 hours. At Jalpan the road forks, a northern branch leading to Concá and Río Verde. This 
branch, which crosses the Río Santa María and the Río Concá about $30 \mathrm{~km}$ by road from Jalpan, is impassable during the high-water season of summer and early fall. In 1956, the eastern branch was passable only as far as Landa de Matamoros, $15 \mathrm{~km}$ by road from Jalpan, but only about $2 \mathrm{~km}$ of new construction remained to be completed to open the road all the way to Xilitla and thence to the Pan-American Highway near Tamazunchale.

Several minor roads branch off the main Bernal-Jalpan route. A 17-km truck road built by the La Concha Mining Co. in 1951-52 from Arquitos to San Pedro Escanela was abandoned in 1953, for washouts made San Pedro Escanela inaccessible to vehicular travel after the rainy season of that year. A separate road from the west leads to Palmas, but Palmas cannot be reached by car from the rest of the Bernal-Jalpan area without driving from Bernal southwest to Querétaro, thence northward through the Estado de Guanajuato and eastward to Palmas, a total driving distance of $175 \mathrm{~km}$ from Bernal.

Most travel in the area is on foot or horseback. All populated places may be reached by trails, which traverse every major ridge. Even the Río Extórax and its large tributaries can be crossed by horseback during the winter and spring seasons.

The junction of the Río Extórax and the Río Moctezuma is one of the most inaccessible places imaginable; dim, brushy trails too steep for horses, mules, or even burros are the only means of descent from the relatively high surrounding country. Near the junction, neither river can be crossed with animals-the Extórax because its canyon floor is covered with enormous limestone blocks that have fallen from the cliffs above, and the Moctezuma because of its dangerous rapids. The Moctezuma is so large and swift that it is unfordable, and for many kilometers the only place where it can be crossed is over a narrow suspension bridge about $10 \mathrm{~km}$ east of the mouth of the Rio Extórax.

\section{TOPOGRAPHY AND DRAINAGE}

The Bernal-Jalpan area is almost entirely within the extremely rugged Sierra Madre Oriental physiographic province. Altitudes range from $700 \mathrm{~m}$ above sea level at the junction of the Río Extórax and the Río Moctezuma (fig. 12) to nearly 3,200 $\mathrm{m}$ at the top of Cerro del Pinguiical. The southwestern corner of the area near Bernal, which is at the northwest edge of an extensive plain 2,0002,100 $\mathrm{m}$ above sea level, belongs to the Mexican Highland province.

The vaguely defined Sierra Gorda extends from Jalpan westward across most of the Estado de Querétaro. The name "Sierra Gorda" is employed on old maps, but is little used locally at the present time. The chief eminences of the Sierra Gorda are Cerro del Pingüical 


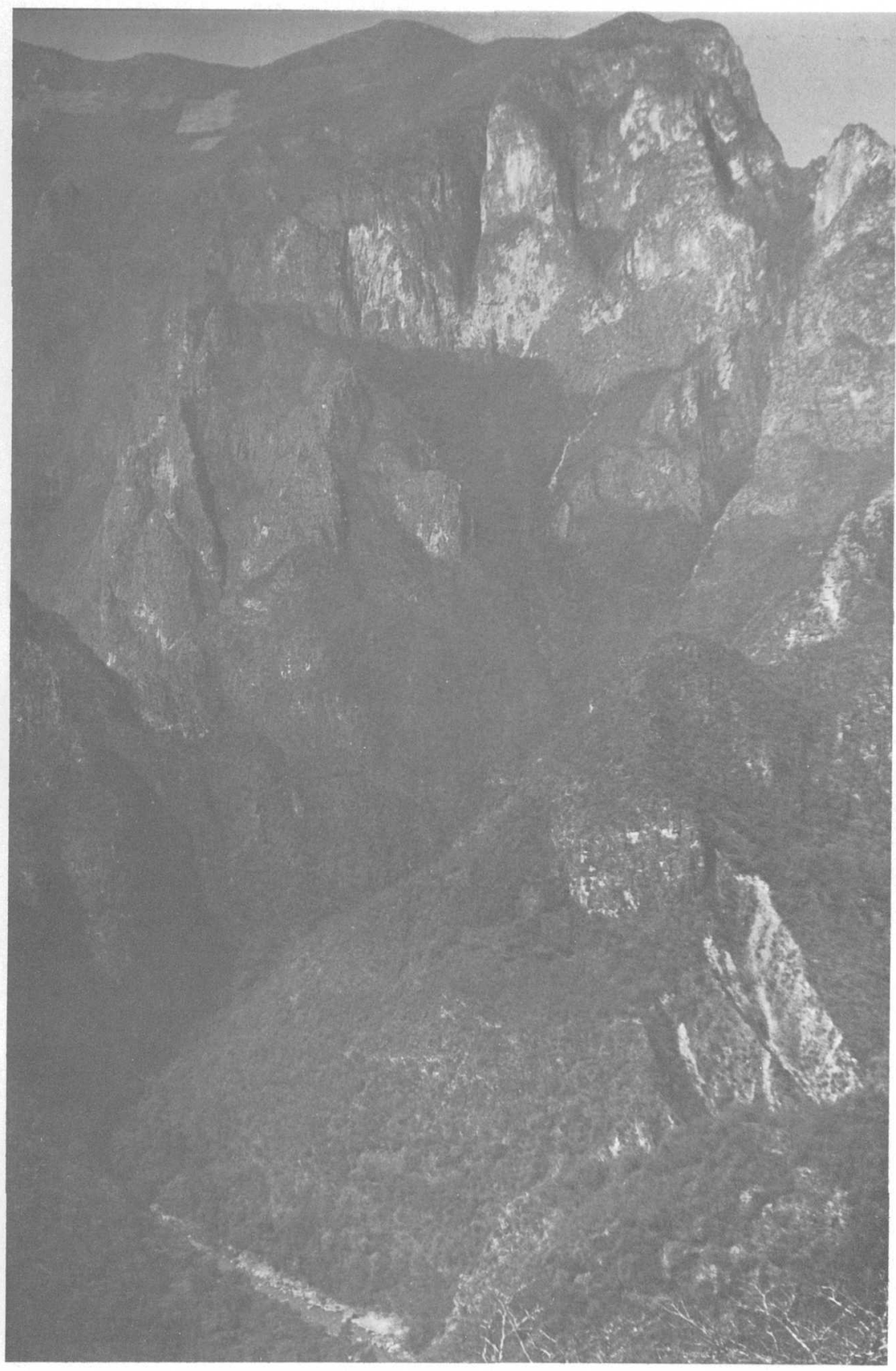

Figure 12.-View southwestward up to the Río Moctezuma from its junction with the Río Extórax. 
and Cerro de la Calentura, whose rounded summits lie along a broad ridge extending northward beyond the area here described. Southward, and also outside the area, lies the high Cerro Ladrón. A narrow east-west zone of deeply dissected lowland threaded by the Río Extórax separates the broad-topped mountain masses that rise more than $2,000 \mathrm{~m}$ above the river to the north and south. Through this zone the Extórax has carved a narrow gorge about $40 \mathrm{~km}$ long with walls rising vertically in places for many tens of meters (fig. 13). The spectacular scenery along the Río Extórax between Bucareli and Las Medias and at its junction with the Río Moctezuma is of national-park quality.

The Río Jalpan and the Río Blanco drain the northern part of the area. The Río Jalpan, fed by many strongly flowing headwater tributaries, flows through a relatively broad mountain valley for about $34 \mathrm{~km}$ before it reaches the Río Santa María (or Río Ayutla) $23 \mathrm{~km}$ north-northwest of the town of Jalpan. The valley of the Río Jalpan is divided into an upper and a lower segment by a constriction at Puente de Dios where the river has developed an underground channel through the toe of a limestone ridge. The Río Blanco rises in strong springs near the village of Río Blanco and flows through a mountain valley to join the Santa María at Atarjea, Guanajuato, $6.5 \mathrm{~km}$ north of Río Blanco.

An unnamed tributary of the Río San Juan drains the extreme southwestern corner of the area.

\section{CLIMATE}

It is not surprising that an area of such great differences in altitude as that between Bernal and Jalpan should have great differences in climate. The highlands are temperate and the lowlands are tropical. As in other parts of western North America, the mountain tops receive more rainfall than the valley bottoms. Thus, Pinal de Amoles has a cool climate and about $800 \mathrm{~mm}$ of rainfall annually, but nearby Bucareli, 1,200 $\mathrm{m}$ lower, is hot and has only about 400 $\mathrm{mm}$ of rainfall annually.

The Río Extórax and its principal tributary, the Tolimán, pass through the most arid part of the whole area near Palmas, Tolimán, and Peñamiller (annual rainfall $300-350 \mathrm{~mm}$ ); then, as the river flows eastward, it passes through country that is increasingly humid, until at the Extórax-Moctezuma junction the annual rainfall is probably $600 \mathrm{~mm}$. As the combined river flows eastward outside the area, it passes into one of the wettest parts of Mexico, that of southeastern San Luis Potosí, where the annual rainfall exceeds 2,500 $\mathrm{mm}$. The moisture-laden winds blow from the Gulf westward; thus Cerro del Pingüical, Cerro de la Calentura, and the high country to 


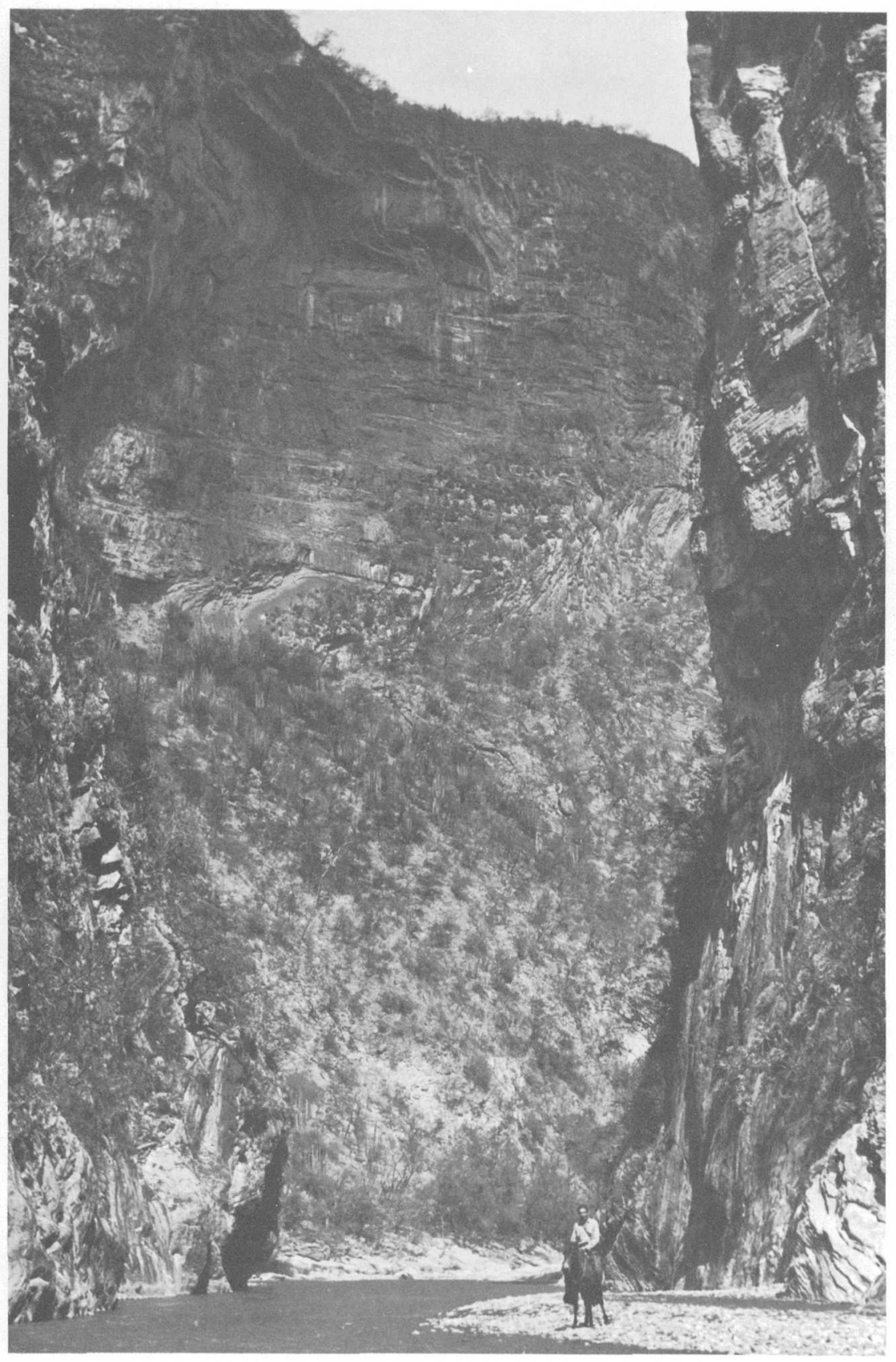

Figure 13.-Canyon of the Río Extorax between Bucareli and Las Medias. The horizontal beds above the slide rock are El Doctor limestone. 
the south of the Extórax cast a rain shadow over the western part of the area.

Rainfall here, as in other parts of central and southern Mexico, is strongly seasonal; about 90 percent occurs between early June and late October. In the winter months highland areas like that of Pinal de Amoles tend to be blanketed in fog, particularly on mornings and evenings, but the late morning sun usually dissipates the fog. Frost usually occurs in the highlands on clear nights during the period from November to February, but the temperature seldom drops lower than $5^{\circ}-10^{\circ} \mathrm{C}$ below freezing. The warmest months of the year are April and May.

\section{VEGETATION}

Associations of native plants show as much variation within the Bernal-Jalpan area as do the topography and climate. Three major associations are those of thorny desert, brushland, and highland forest.

The thorny desert plant association characterizes a broad zone that lies west of the central highland. Many cacti, including varieties of cholla, prickly pear, organpipe, and barrel cactus, are picturesque features of the landscape near Bernal, Tolimán, Peñamiller, and Palmas. The hilly country south of Cerro del Zacamecate, which lies about $7 \mathrm{~km}$ southeast of Tolimán, has perhaps the richest cactus flora in the region; at that locality, exotic garambullo (Cereus garambullos), órgano (Cereus excelsus), biznaga (Mamillaria magnanima), and tasajo occur abundantly with the more familiar nopal (prickly pear). Edible fruits from these cacti include a purple berry from the candelabralike garambullo, the plum-size pitahaya and tuna from Cereus pitahaya and Cactus opuntia, and the small pepper-shaped "chilito" from the barrellike biznaga. Almost equally abundant bladed plants of the region include maguey silvestre, sotol, huapilla, and "palmito" (local name for a tall yuccalike plant resembling the Joshua tree of southeastern California). Greasewood or creosote bush, mesquite (Prosopis dulcis), catsclaw, huamúchil (Mimosa unguiscati), and ocotillo are also present. The greasewood forms almost pure stands in the vicinity of Higuerillas. Native succulents include the stapelia, or carrion flower. Thickets of bamboolike carrizo and of broad-leaf willows (Salix grandiflora) grow along the main desert streams, but large trees are rare because floods periodically carry away most of the vegetation that grows near the water.

Desert plants tend to be more widely dispersed on limestone than on other bedrock terrains. This selectivity is locally an aid to mapping, especially on aerial photographs. 
Brushland plant association characterizes most of the terrain east of the central highland and shows a transition zone westward to thorny desert in the canyon country that penetrates the highland. East of Jalpan the generally dense and high brush grades locally into a brushy woodland where gnarled oaks (Quercus mexicanus) and black walnut (Juglans nigra) trees are interspersed with many varieties of deciduous shrubs. Huizache (Mimosa sp.), tepame (Acacia cornigera), and salvia are among the chief brushy plants. Long grass forms a mat under the trees and bushes, which may be leafless during the long dry season but which bear abundant foliage from June to November. The long, steep slopes that rise above the junction of the Río Extórax and Río Moctezuma are blanketed with brushy jungle growth that includes the exotic junquillo (a yellowblossoming shrub) and the mocoque (a tree bearing a green mangoshaped fruit). The brush thins to the west and is interspersed with órganos at the longitude of Las Medias.

The highland forest association characterizes much of the central part of the Bernal-Jalpan area and shows transition zones westward to thorny desert and eastward to brushland. Pines cloak most of the summit areas of the Cerro del Pingüical and the Cerro de la Calentura; they form an almost continuous cover northward to the state boundary and eastward to Pinal de Amoles. Dense thickets of stiff-barked brush bearing brown berries and resembling the manzanita of southwestern United States cover some of the highest summits and sloping areas of the region; they are found on the very top of the Cerro del Pingüical (named for pingüicas, the berrylike fruit of Arctostaphylos pungens). Downward on all sides from the highest parts, the pines become mixed with oaks, crabapple trees, madrones, and various shrubs; lower still, particularly in the vicinity of Río Blanco, the pines and nonconiferous trees make way for piñons and cedars.

\section{WATER SUPPLY AND AGRICULTURE}

Most of the Bernal-Jalpan area is uncultivated because of the scanty rainfall in the western part and the rugged terrain in the eastern part. Stockraising is widespread and is one of the chief sources of livelihood.

In the vicinity of Bernal, Tolimán, and San Pablo, where most of the flatland lies, farming can be conducted successfully only with irrigation, but very little water is available for irrigation at those places. A few kilometers to the southwest of Bernal ground water occurring $45 \mathrm{~m}$ below the surface is lifted by diesel pumps and is used for irrigating alfalfa and other crops. The Río Bernal and the Río Tolimán supply small amounts of surface water for irrigation 
at San Pablo and Tolimán, where the production of corn, beans, and other staples is barely sufficient to supply local needs.

Narrow fields are cultivated along the banks of the Río Extórax near Peñamiller, Los Sebastianes, San Lorenzo, and Peña Blanca, as well as along the tributaries Arroyo del Saucillo and Arroyo del Pilón. Surface flow at those places is intermittent, but there is permanent, though meager, underground flow. Shallow holes dug in the sandy river bed quickly fill with water, and at such places, particularly near Peñamiller, charqueaderos, described below, are employed for lifting the water to ditches on the bank.

The charqueadero consists of two or three wooden scoops with long handles attached to a pivotal bar. Men stationed at the ends of the handles dip the scoops in the dug holes and push in unison to lift the water $1-1.5 \mathrm{~m}$ to the top of the river bank. Where bedrock is exposed in the watercourses, the underground flow is forced to the surface, and at such places diversion works and small ditches carry a meager flow of water to beans, corn, squash, or chili planted in rows a few meters long. Hedgelike rows of carrizos, willows, or pirules (pepper trees) planted along the edges of the river help to protect the tiny fields from flash floods. New fields to replace those destroyed by floods are made by building dams across the mouths of tributary draws so that sediment can collect behind them.

East of the central highland, many streams are perennial, but much of the land is too deeply dissected for cultivation. At Las Medias the valley of the Río Extórax is broad enough for cultivation of a few tens of hectares of sugar cane. Piloncillo (unrefined sugar) and aguardiente (cane brandy) are manufactured at Las Medias and carried by animals up a long, steep trail to Pinal de Amoles. Sugar cane is the chief crop along the Río Jalpan near Aguacatlán, where all the dry-season flow of that stream is utilized for irrigation. Small acreages of bananas, citrus fruits, avocados, papayas, and mangos are cultivated at Plátano, Las Medias, Santa Clara, Aguacatlán, and Jalpan.

In the highland region of Pinal de Amoles, grains, potatoes, beans, chili, chick peas, and other crops are grown without irrigation. Much of the original forest cover has been cleared for crop raising, except where the terrain is too steep to be cultivated. Highland orchards produce apples, pears, peaches, and plums, but the area is so far from outside markets that most of the fruit grown is consumed locally.

Grazing animals are raised throughout the area, although usually in small numbers. Even the dry hills and valleys of the western part, where there is little grass, support flocks of goats and sheep. Watering places for the stock in the western part are provided by 
earthen dams which catch storm waters or by wells from which water is piped to troughs. At places the ground water is drawn from wells as much as $40 \mathrm{~m}$ deep, in buckets lifted by horse-powered winches. In the eastern part, where water and grass are more plentiful, the flocks are more numerous and there are also small herds of range cattle. Dairy farming is of economic importance near Bernal, where the cows are fed locally grown alfalfa. Most of the milk is trucked to a cannery in the city of Querétaro.

\section{ARCHEOLOGY}

Coecillos (conical-shaped rubble mounds) and the stone foundations of ancient buildings and moats or trenches are found at several places. They are evidence of a pre-Hispanic civilization in the Bernal-Jalpan area. These ruins, as well as those of Toluquilla and Ranas, southwest of the area, were described by J. M. Reyes, who visited the Sierra Gorda in April 1879. The largest of the local archeological sites is probably that of Los Moctezumas, where coecillos extend over an area about $600 \mathrm{~m}$ long, from northeast to southwest, by $80 \mathrm{~m}$ wide. This site, along the route followed since time immemorial by the people of Pinal de Amoles, is halfway up the long grade between E1 Pilón and the top of the Sierra Gorda (Reyes, $1880 \mathrm{~b})$; it is approximately located on plate $2 . \quad$ Reyes mentioned other coecillos at La Plazuela, "one and one-half leagues" $(6 \mathrm{~km})$ south of Los Moctezumas, but this site could not be placed on the map by the present writer. Other ruins cited by Reyes are approximately located on plate 2 at the following places: Arquitos, Agua del Cuervo, and Puerto de las Vigas, all along the ancient (and modern) route of travel between Pinal de Amoles and Jalpan; at Rancho Rodesno, northwest of the route; and at Tonatico, southeast of the route.

The Indians who constructed the now-ruined buildings at the places listed above were probably neither Aztec nor Toltec, but earlier and more primitive peoples. The stones used for construction were not cut, but were left in their natural shape and simply placed in the most favorable positions for joining. Many of the present inhabitants of the region are Otomi Indians, but there is some mixture with the Huastecos to the east (Velasco, 1891) and possibly with the Tarascans to the west (Quiroz-Martínez, 1932).

\section{SEDIMENTARY, METAMORPHIC, AND VOLCANIC ROCKS}

Descriptions of the local units are based on a series of observations made at separate localities. In general, the exposures are discontinuous and the differences between exposures are appreciable. Place names of stratigraphic-observation localities that appear in the text 
are shown on plate 2. Listing of descriptions of the Las Trancas formation and the $\mathrm{El}$ Doctor limestone is from west to east.

\section{JURASSIC SYSTEM OR OLDER}

\section{PRE-LAS TRANCAS ROCKS}

The oldest rocks that crop out in the Bernal-Jalpan area consist of mica schist containing stubby lenses of quartzite as much as $1 \mathrm{~m}$ long and interbeds of dark-gray quartzite as much as $1.5 \mathrm{~m}$ thick. Foliation planes in the schist are wavy. These rocks have an outcrop width of more than $2 \mathrm{~km}$ along the Río Tolimán in the vicinity of Chilar, which is about $5 \mathrm{~km}$ northeast of Tolimán. No fossils were found in these metamorphic rocks, which are not younger than Middel Jurassic and which may be as old as Paleozoic. Their thickness is unknown.

\section{JURASSIC SYSTEM}

\section{LAS TRANCAS FORMATION}

The schist and quartzite near Chilar are overlain uncomformably by black, thinly fissile phyllitic shale containing sandstone and claystone concretions, detrital mica, and interbeds of coarse graywacke; the graywacke in places contains pebble conglomerate. These rocks, referred to the Las Trancas formation, are exposed not only in the Chilar area but also at two places near Bernal, where a stratigraphic thickness of $100-200 \mathrm{~m}$ can be seen.

About $1 \mathrm{~km}$ north of the town of Bernal, the black phyllitic shale is overlain conformably by a limestone bed $2-3 \mathrm{~m}$ thick, which is probably lenticular inasmuch as it does not appear farther north of Bernal. Near Bernal a section of red phyllitic shale 100-200 m thick appears above the limestone bed. The red shale is intercalated with coarse-grained grayish-green and grayish-purple bentonitic beds as much as $30 \mathrm{~cm}$ thick and with lenses $5-10 \mathrm{~cm}$ in diameter. The red beds seem to be missing in the section near Chilar. Both the limestone and red shale are referred to the Las Trancas formation.

No fossils were found in the lower part of the Las Trancas formation. The red beds are lithologically similar to parts of the Huizachal formation, whose type locality is several hundred kilometers to the north and which is considered to be of late Middle Jurassic age or early Late Jurassic age.

About $3 \mathrm{~km}$ northeast of Bernal, the red beds are overlain with probable conformity by dark-gray conglomerate a few meters thick, which contains at or near its base a bed of coquina replete with nonribbed oysters. The conglomerate is made up largely of well-rounded pebbles of sandstone and graywacke and is overlain by interbedded fine-grained graywacke and shale, which grade upward into arkosic 
conglomerate. This section is $50 \mathrm{~m}$ thick. Farther north it is overlain by about $50 \mathrm{~m}$ of shale and dark-gray phyllitic microlaminated argillaceous limestone or calcareous siltstone that is overlain in turn by the El Doctor limestone. Both sections are missing south of Bernal.

In the northwestern part of the area mapped, within the triangle defined by Tolimán, Palmas, and Peñamiller, the exposed parts of the Las Trancas formation consist of sand- to pebble-size graywacke interbedded with dark-gray calcareous mudstone and phyllitic shale in beds as much as $1 \mathrm{~m}$ thick and in stubby lenses as much as $25 \mathrm{~cm}$ thick. Indeterminate ammonites and pelecypod fragments were found in the pebble conglomerate on the east slope of Cerro de la Muneca about $5 \mathrm{~km}$ west of Higuerillas. The shale is slightly greenish-gray in places, and some chert nodules are present.

In Arroyo del Saucillo, $3 \mathrm{~km}$ north-northwest of Peñamiller, black carbonaceous limestone that probably lies somewhere near the middle of the Las Trancas formation is overlain by graywacke and graywacke conglomerate beds totaling. about $10 \mathrm{~m}$ in thickness. The gray wacke conglomerate contains pebbles of black carbonaceous limestone as much as $5 \mathrm{~cm}$ in diameter, much sand-size quartz and feldspar, and small chert beds and lenses. Fissile thin-bedded black carbonaceous limestone $10 \mathrm{~m}$ thick overlies the graywacke and is overlain by about $25 \mathrm{~m}$ of slightly phyllitic shale. El Doctor limestone directly overlies this shale. The observed overlapping sections indicate that the Las Trancas formation is probably between 500 and $1,000 \mathrm{~m}$ thick in the northwestern part of the area.

The section of dark-colored laminated calcareous rocks in the upper part of the Las Trancas formation increases in thickness eastward to $200 \mathrm{~m}$ or more. Along the Río Extórax about $3 \mathrm{~km}$ east of Peña Blanca, the formation is about two-thirds impure fissile darkgray pyritiferous limestone or calcareous mudstone with rare interbeds of purer nonfissile limestone $30-40 \mathrm{~cm}$ thick, and about one-third shale with a few interbeds of coarser, more quartzitic rock. The easternmost exposure of quartzitic rock in the Las Trancas formation, within the area mapped, is a bed of sandstone or graywacke 5-6 m thick containing platy fragments of black calcareous mudstone. This exposure is along the Río Extórax about $2.5 \mathrm{~km}$ southwest of Bucareli.

The following fossils were found east of Peña Blanca in a pebbleconglomerate bed $0.5 \mathrm{~m}$ thick, $4 \mathrm{~m}$ below a contact with the overlying El Doctor limestone: (a) regular echinoid with perforated tubercle and (b) irregular echinoid, possibly a cassiduloid. Neither specimen could be classified as to genus or species.

For several kilometers east and north of Bucareli, exposed parts of the Las Trancas formation consist of fissile, slightly phyllitic car- 
bonaceous mudstone in beds $30-70 \mathrm{~cm}$ thick alternating with beds $5-15 \mathrm{~cm}$ thick. The thinner beds weather to medium gray and the thicker ones to light gray; the color change imparts a banded appearance to most outcrops. These beds are overlain by fissile argillaceous limestone beds as much as $30 \mathrm{~cm}$ thick interbedded with nonfissile purer limestone beds as much as $40 \mathrm{~cm}$ thick.

Northward at Cuesta de Huasmazontla, which is on the road between Pinal de Amoles and Jalpan and a few kilometers east of Mina Grande, the formation consists of splintery-weathering, slightly phyllitic gray shale, dark-gray argillaceous limestone that is microbedded in part and that contains small quartz grains, and scattered beds of impure calcarenite. Ammonites $5-10 \mathrm{~cm}$ in diameter with perisphinctid ribbing (probably of the genus Paradontoceras), some small uncoiled ammonites (probably Protancycloceras), as well as a pelecypod similar to Parallelodon (R. W. Imlay, written communications, June 3 ; Sept. 2, 1953) were found in these beds. A poorly preserved ammonite about $30 \mathrm{~cm}$ in diameter, obtained from a road cut at Cuesta de Huasmazontla, was unidentifiable.

In the eastern part of the area mapped, south of San Pedro Escanela and along the Río Extórax in the vicinity of Las Medias, outcrops of the formation consist of dark-gray thin-bedded impure limestone, numerous shaly interbeds, and a few bluish-green bentonitic(?) beds $5 \mathrm{~cm}-1 \mathrm{~m}$ thick (fig. 14). Perisphinctid ammonites and Protancycloceras were found on a hillside just east of Las Medias. The Río Extórax passes through mountain valleys with closely spaced gullies on the sloping sides, where it is eroding the Las Trancas formation at Las Medias and Santa Clara (fig. 15), as contrasted with the narrow, vertically walled gorges elsewhere.

At Puerto de Las Trancas, Hidalgo, about $35 \mathrm{~km}$ southeast of Las Medias and the type locality of the Las Trancas formation, where the age of the unit is considered to be late Kimmeridgian and Portlandian, the lowermost beds are not exposed (Segerstrom, 1956). Unfortunately, the oysters found northeast of Bernal and on the east slope of Cerro de la Muñeca give no clue to the age of lower beds, except that the smooth oysters northeast of Bernal are postTriassic. Oysters did not exist before Late Triassic time, and all known Triassic oysters are strongly ribbed. The Protancycloceras found in the upper part of the formation near Las Medias is very similar to $P$. hondense Imlay (Imlay, 1942) from the Portlandian of Cuba. The perisphinctids or berriasellids collected at Cuesta de Huasmozontla resemble the ammonites from the uppermost Jurassic strata near Mazapil, Zacatecas (R. W. Imlay, written communication, June 3, 1953). 


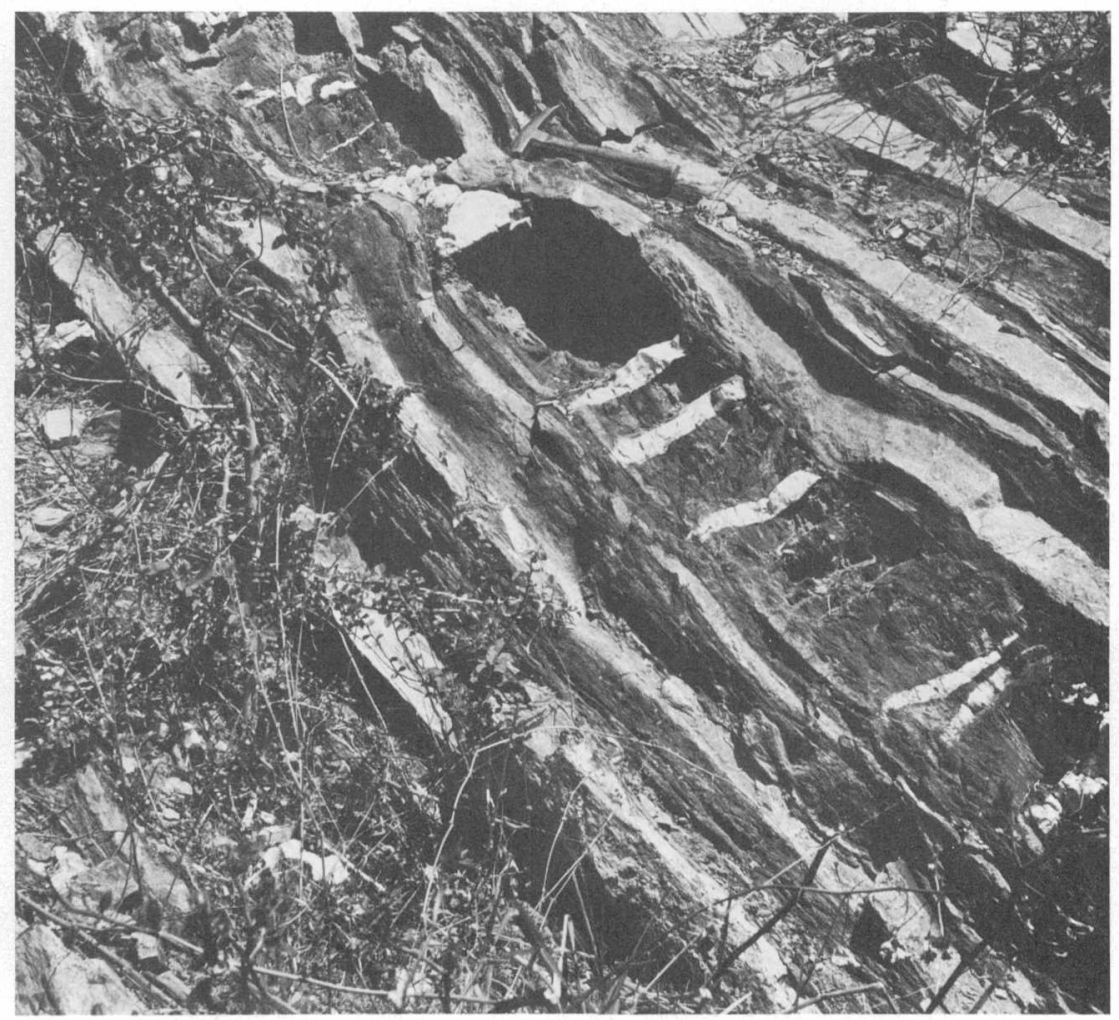

Figure 14.- Steeply dipping beds of the Las Trancas formation on a slope near the mouth of Arroyo del Limon $17.5 \mathrm{~km}$ southeast of Pinal de Amoles.

A specimen of "Aspidoceras," group of $A$. perarmatum Sowerby, was reported by Burckhardt (1930, p. 81) to have been found in compact black limestone at Jalpan. This group is now referred to the genus Euaspidoceras of late Callovian to late Oxfordian age. Inasmuch as the town of Jalpan is underlain by beds of Late Cretaceous age, the Euaspidoceras was most likely collected elsewhere in the municipality of Jalpan, probably in the vicinity of Santa Clara, where the Las Trancas formation crops out in a belt $13-17 \mathrm{~km}$ south of the town of Jalpan. Ammonites of the similar genus Euaspidoceras were found in the Tamán formation in the Tamazunchale region, about $60 \mathrm{~km}$ east of Jalpan; these are of Kimmeridgian age (Imlay, 1952, p. 971) and show that the Tamán formation is somewhat younger than the upper part of the Las Trancas formation near Jalpan. 


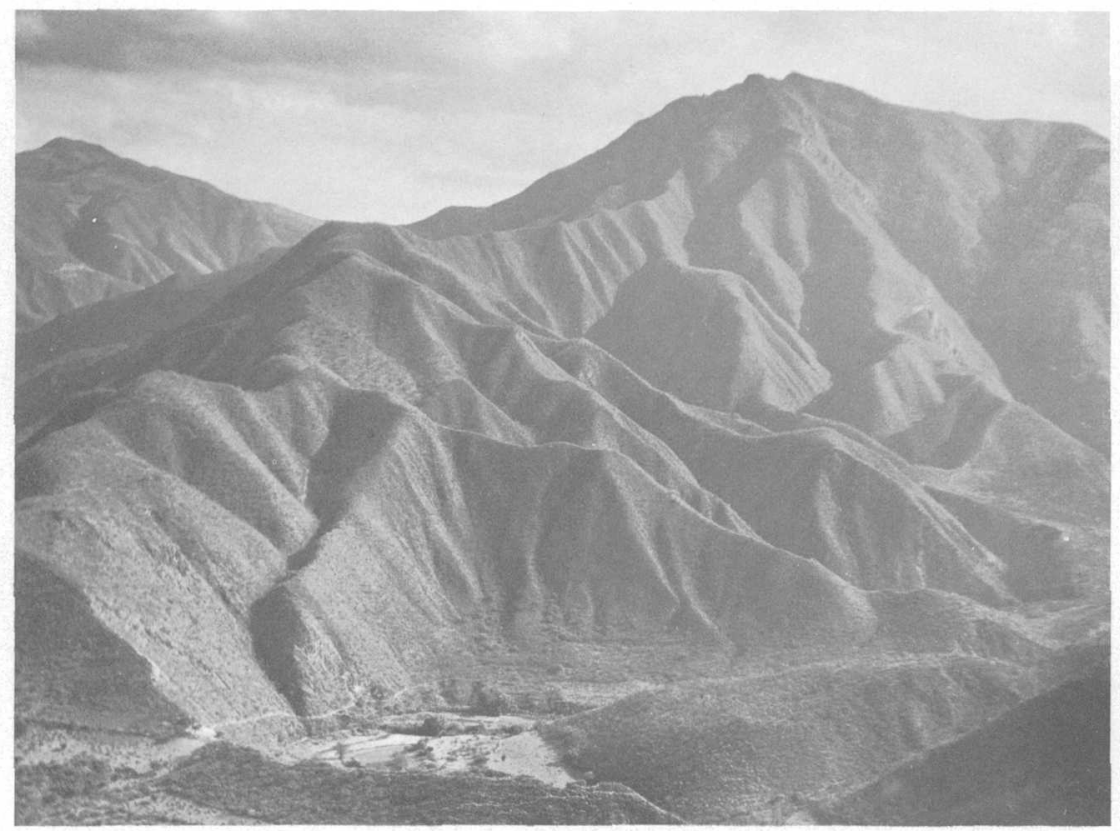

Figure 15.-Typical erosional surface of the Las Trancas formation. The view is south across the valley of the Río Extorax from the trail that leads from San Pedro Escanela to Las Medias.

\section{CRETACEOUS SYSTEM}

\section{EL DOCTOR LIMESTONE}

The El Doctor limestone is the most widely occurring rock unit in the area mapped. It overlies the Las Trancas formation with great disconformity in the western part of the area and with much less disconformity in the eastern part. Despite the seemingly conflicting evidence of steeper dips in the poorly competent older beds in the western part of the area, there is no apparent angular unconformity between the El Doctor limestone and underlying rocks where the contact is well exposed, as in the gorges along the Río Extórax.

Two kilometers west of Higuerillas the basal part of the El Doctor limestone consists of a few meters of breccia containing angular fragments as much as 15 or $20 \mathrm{~cm}$ in diameter; it is composed chiefly of limestone and in smaller part of chert, quartzite, arkose, and graywacke, in a coarse-grained fetid limestone matrix. The breccia grades upward into thick-bedded calcarenite and finer grained limestone with chert lenses. The beds become thinner upward in the section, which has a total thickness of several tens of meters. The fauna in the basal beds include a globose ammonite that has a maximum diameter of $4 \mathrm{~cm}$ and a very small umbilicus, several species 
of small, openly coiled ammonites, a lytocerid ammonite, and poorly preserved gastropods and belemnites. The small, openly coiled ammonites include Hamites?, Hamulina?, Ptychoceras?, and Diptychoceras? (R. W. Imlay, written communication March 10, 1953).

East, south, and north of Adjuntas de Higuera the formation thickens rapidly to hundreds of meters. Eleven kilometers north of Adjuntas de Higuera, in the Soyatal antimony district, the El Doctor limestone is probably about $200 \mathrm{~m}$ thick. The upper part of the limestone here and a part of the overlying formation have been divided into three mappable units, described briefly by White (1948) as follows: "The lower formation consists of an unknown thickness of limestone, chert, limestone conglomerate, shaly limestone, and a little calcareous shale. The middle formation generally consists of about $30 \mathrm{~m}$ of thin-bedded limestone characterized by numerous lenses of chert. The beds in the lower $1-40 \mathrm{~m}$ (of the upper unit) consist predominantly of limestone conglomerate and massive limestone." White's lower and middle formations plus the lower $40 \mathrm{~m}$ of his upper formation are the El Doctor limestone.

A short distance south of Soyatal the upper part of the El Doctor limestone consists of conglomerate, several tens of meters thick, containing well-sorted pebbles of limestone in one part, and angular slabs of limestone and chert, 10 to 25 times as long as they are thick, in another part.

In the north western part of the area mapped, northwestward from near Adjuntas de Higuera and along the Río Extórax, the thickness of the El Doctor limestone does not exceed a few tens of meters. Where the entire formation ranges in thickness from only about $4 \mathrm{~m}$ (3 km west of Adjuntas de Higuera) to about $20 \mathrm{~m}$ (along Arroyo del Saucillo northwest of Peñamiller and northeast of Palmas), the unit tends to be massive or thick bedded, coarse grained, partly brecciated, and light to medium gray. Where the unit is somewhat thicker, the basal breccia or calcarenite, which is present almost everywhere in the western part of the area mapped, is commonly overlain by thin-bedded dark-gray limestone and abundant tabular chert. The El Doctor limestone thickens from $30 \mathrm{~m}$ at a point along the Río Extórax $1 \mathrm{~km}$ west of Peñamiller to $150 \mathrm{~m}$ or more at the junction of the Río Extórax and Río Tolimán $5 \mathrm{~km}$ west of Peñamiller. Northwest of Peñamiller the formation remains very thin (15-30 m) for many kilometers.

About $15 \mathrm{~km}$ north of Soyatal, or $1 \mathrm{~km}$ north of Puerto del León, the lower part of the El Doctor limestone contains banded calcarenite interbedded with pebble conglomerate containing lenses of chert. The banded calcarenite consists of alternating dark-gray and lightgray laminae ranging in thickness from $2 \mathrm{~mm}$ to $1 \mathrm{~cm}$. Each dark 
band is made up of fine sand-size grains grading upward to medium sand-size grains. The light-colored bands are coarser grained and do not show graded bedding. The dark-gray beds are more resistant to weathering than the light-gray beds, which tend to form groovelike reentrants in outcrop surfaces. The pebble conglomerate contains siliceous and carbonate pebbles that attain a maximum diameter of $5 \mathrm{~mm}$ in a limestone matrix.

Poorly preserved, openly coiled ammonites, determined by $R . W$. Imlay (written communication, March 10, 1953) as Crioceras? sp., Hamulina? sp., and Macroscaphites? sp., were found in the upper part of White's middle formation (1948) $11 \mathrm{~km}$ north of Adjuntas de Higuera. Observations made by White on the middle formation at Soyatal, where bodies of black and white chert show great variety of form, indicate that the chert bodies are diagenetic in origin (1947).

A section somewhat similar to that at Soyatal is seen in the vicinity of Pinal de Amoles. At the town and for several kilometers to the west and south, the limestone is medium to thick bedded and contains chert nodules and lenses. The beds are fine grained for the most part, but at least one bed of breccia is present. This bed contains limestone fragments as much as $20 \mathrm{~cm}$ long which are bounded in part by thin chert occurring in stringerlike masses. The greatest thickness of limestone beds is about $1.5 \mathrm{~m}$, of chert lenses about 20 $\mathrm{cm}$. Beds of medium thickness tend to be dark colored and somewhat argillaceous, whereas the thicker beds are lighter in color and of purer limestone. At many places thick-bedded fine-grained limestone contains stylolites parallel to the bedding planes. Fossils occurring sparingly in the thick beds include bivalves and unidentified, closely coiled ammonites as much as $3 \mathrm{~cm}$ in diameter, as well as stubby echinoid spines.

Overlying beds that crop out from the Queso-Animas mines nearly to Arquitos, $2.5 \mathrm{~km}$ northeast of Pinal de Amoles, are alternately limestone layers $10-20 \mathrm{~cm}$ thick and chert lenses $2-5 \mathrm{~cm}$ thick. The outcrop width here is many times the stratigraphic thickness because of repeated folding. Small, openly coiled ammonites, which resemble those near Higuerillas, and small narrow gastropods occur in the thin beds at Las Animas mine and $0.75 \mathrm{~km}$ west of Arquitos. The ammonites also occur in thin limestone beds near Rancho Rodesno, $5.5 \mathrm{~km}$ north of Pinal de Amoles; at that place the accompanying chert forms lenticular concretions (fig. 16). Corresponding thin beds in the upper part of the formation far to the northwest of Pinal de Amoles, near Río Blanco, contain molds of the openly coiled ammonites in tabular chert, and about $500 \mathrm{~m}$ southeast of Río Blanco the vertebrae of a fish or of a marine lizard were found in these beds. A 1-meter bed of coarse calcarenite tops the formation just west of the fork of roads to Jalpan and San Pedro Escanela. 


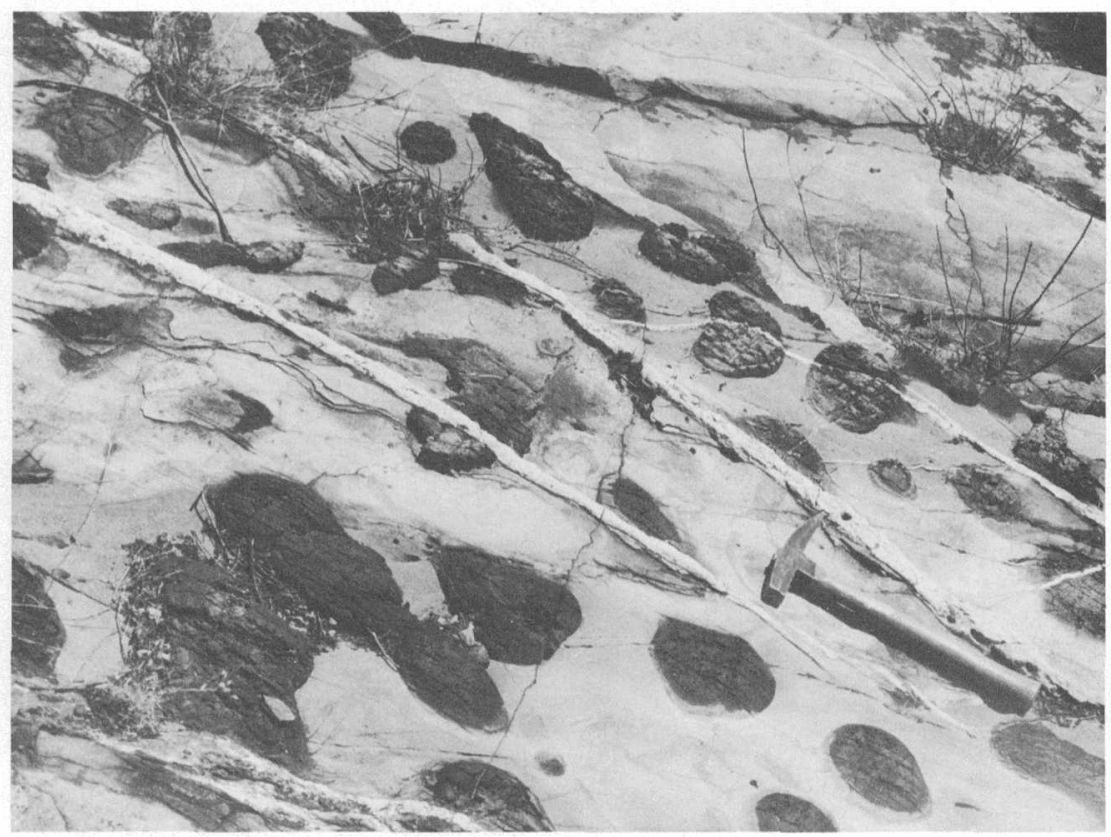

FIGURE 16.--Lens-shaped chert concretions on a weathered surface of the El Doctor limestone.

The total thickness of the El Doctor limestone is probably 200-300 $m$ in the vicinity of Pinal de Amoles; the apparently much greater thickness south of that place is due to repetition of beds by recumbent folding.

A change in the section is noted farther east. On the Río Extórax between Las Medias and Santa Clara the base of the El Doctor limestone is made up of thin-bedded limestone and much tabular chert. These beds are overlain by medium- to thick-bedded limestone with chert pods containing small, poorly preserved unidentifiable bivalves. About $1 \mathrm{~km}$ southwest of Las Medias, limestone beds 2-3 m thick stand up like walls, because their resistance to erosion is greater than that of adjacent thinner beds (fig. 17).

A great bank of the El Doctor limestone extending about $50 \mathrm{~km}$ southeastward from Adjuntas de Higuera attains a maximum width of $20 \mathrm{~km}$ and a maximum thickness of $1,500 \mathrm{~m}$. This major feature, which is outside the area mapped by the author, is called the Cerro Ladrón Bank. The bank consists of thick-bedded limestone, much of it coarse-grained. The bank facies and three other facies of the El Doctor limestone in an area centering around the village of El Doctor were mapped and studied in 1952-54 by Wilson and two associates who named and defined the El Doctor limestone unit and described its facies (1955). 


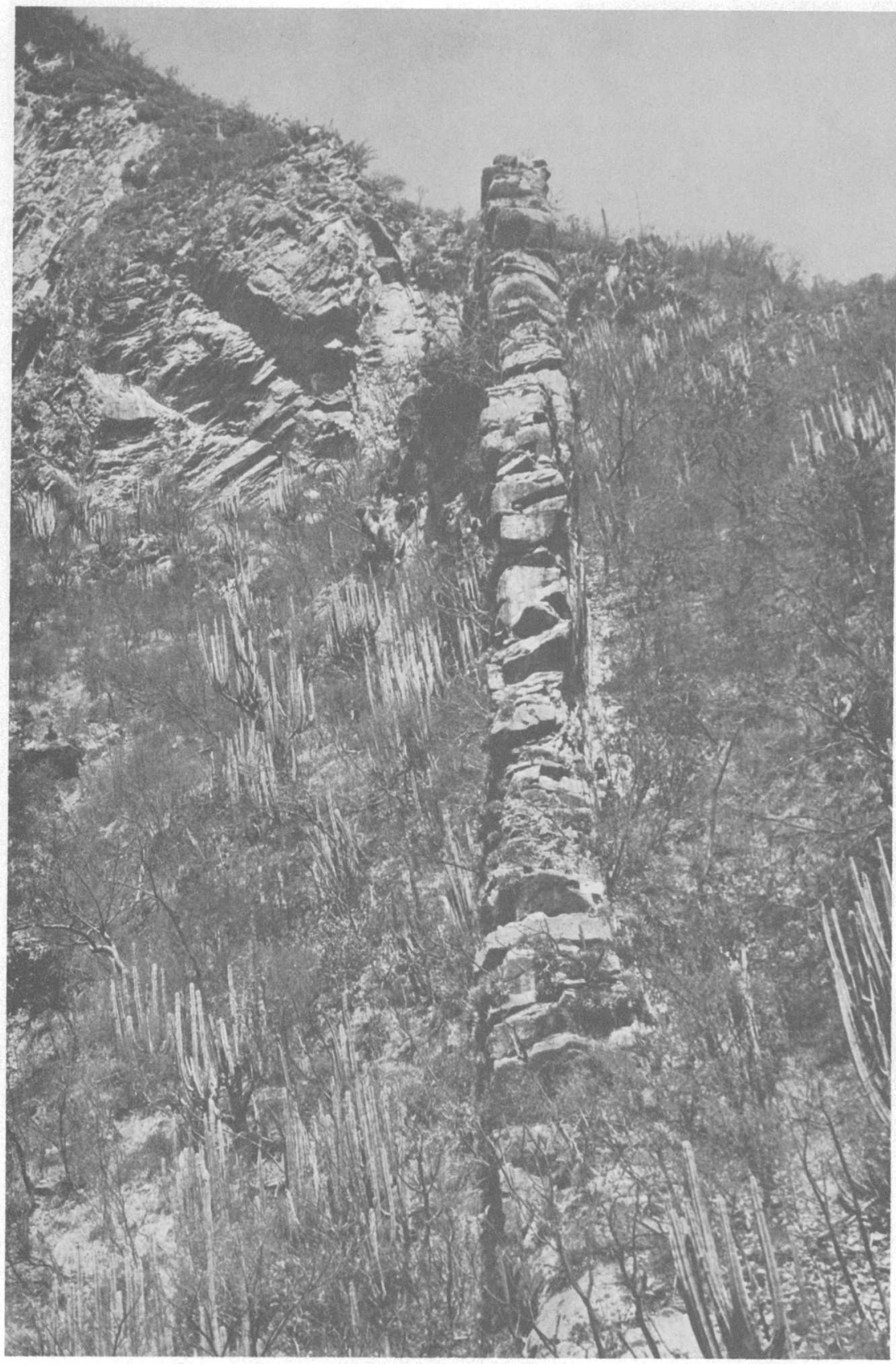

Figure 17.-A nearly vertical bed of El Doctor limestone, about $1 \mathrm{~km}$ southwest of Las Medias. 
The Jacala Bank, also of El Doctor limestone, crosses the eastern part of the area. This limestone bank lies east of Jalpan, extends $50 \mathrm{~km}$ to the southeast and about $25 \mathrm{~km}$ to the north of that place, and has a maximum width of several tens of kilometers (Bodenlos, 1956). The Jacala Bank east of Jalpan consists of thick-bedded light-gray limestone. Many of the beds are calcarenite and a few of them are breccia, conglomerate, or biostromes. Irregular masses of brown chert are present in some of the beds, but no well-defined lenses or nodules of black or white chert were seen in the bank facies. Among the fauna observed were gastropods (Nerinea) and thinshelled rudistids (Toucasia) near the edge of the bank $5.5 \mathrm{~km}$ southeast of Jalpan. Fragments of Toucasia were observed well inside the bank at the junction of the Río Extórax and Río Moctezuma $16 \mathrm{~km}$ southeast of Jalpan. The fossiliferous beds at both localities are more than $1 \mathrm{~m}$ thick, and they range in texture from calcarenite to calcirudite. The bank in the southeast corner of the area is probably almost $1,000 \mathrm{~m}$ thick.

Rudistids are not entirely restricted to the Jacala Bank. Broken forms, including Radiolites, occur with Nerinea in thick-bedded limestone outside the bank area $5 \mathrm{~km}$ west of Jalpan, and unidentified rudistid fragments were found $2 \mathrm{~km}$ southeast of Pinal de Amoles in thick-bedded limestone containing chert nodules.

The following general statements can be made about the El Doctor limestone in the Bernal-Jalpan area: (a) In the western part of the area, where the formation is thin, the unit is all breccia and calcarenite; (b) in the central part, where the formation is much thicker, it consists of calcarenite at the bottom and thin-bedded limestone at the top; (c) in the eastern part of the area the formation is either bank facies throughout, or it is thin bedded and contains tabular chert at both the bottom and top, with beds of greater thickness in between; (d) in the central and eastern parts of the area the beds in the middle of the formation show as great a variety of lithologic types vertically as do the facies of Wilson and others laterally.

El Doctor limestone is strongly resistant to erosion; it tends to form narrow, vertically walled gorges along the principal watercourses and great cliffs on higher slopes of the mountains (fig. 18).

Faunal remains in the Bernal-Jalpan area indicate that the age of the El Doctor limestone is largely Albian and possibly ranges from early Albian to early Cenomanian. The base of the formation may be late Albian in the southwestern part of the area, and middle or early Albian in the northern, northeastern, and eastern parts of the area. A long hiatus of time, from the Tithonian stage (uppermost Jurassic) through the Aptian and into the Albian stage, is thus indicated between deposition of the Las Trancas formation and the basal beds of the El Doctor limestone. 


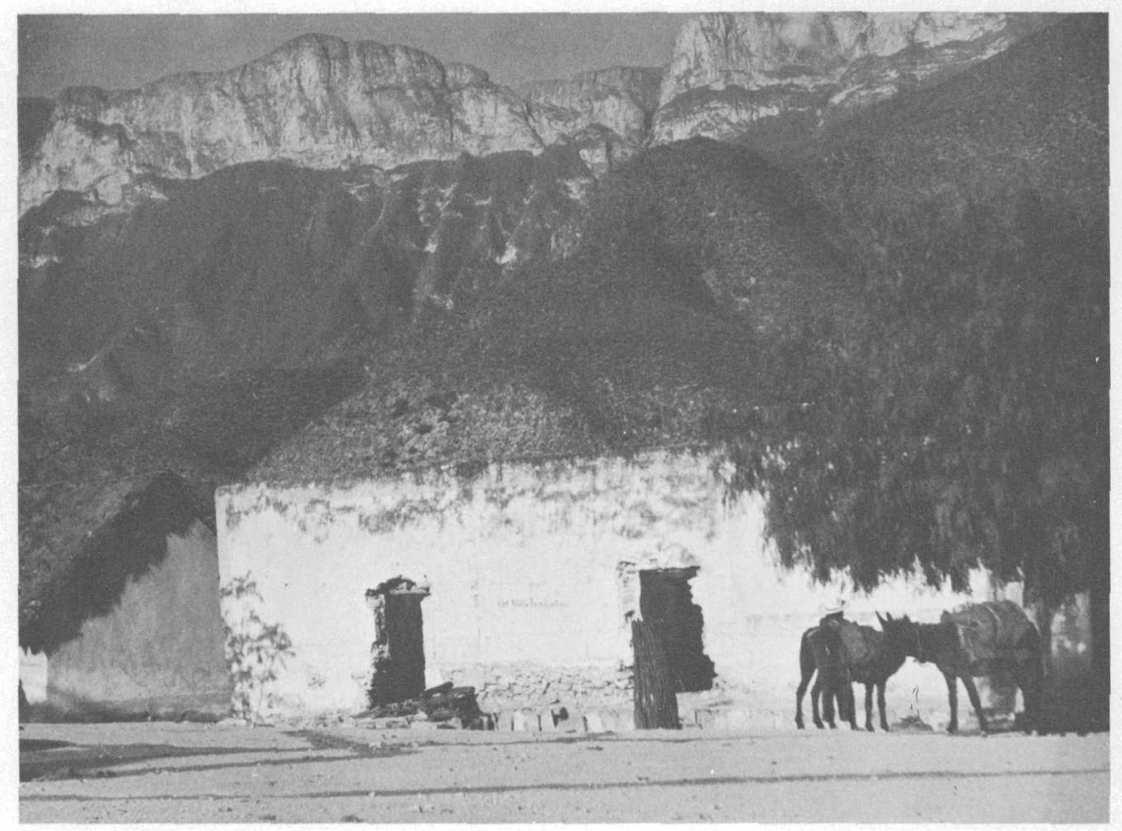

FIGURE 18.-The Las Trancas formation (below) and the El Doctor limestone (above). The contact is at the base of the great cliffs that rise in the distance beyond the town of Bucareli.

SOYATAL AND MEXCALA FORMATIONS, UNDIFFERENTIATED

Thin-bedded fine-grained dark-gray limestone with interbeds of yellow-weathering shale, mudstone, and siltstone overlies the El Doctor limestone, possibly disconformably, but certainly without angular unconformity. The contact between the formations is drawn where abundant chert or thick-bedded limestone disappears and conspicuous clastic beds begin to appear. These beds are assigned to the Soyatal formation.

The Soyatal formation is also predominantly limestone, but, unlike the El Doctor limestone, it contains numerous interbeds of shale, siltstone, or sandstone. Still higher in the section the strata become predominantly clastic and are assigned to the Mexcala formation. The upper unit contains limestone interbeds, but they are uncommon. The vertical change from Soyatal to Mexcala strata is gradational and the contact is considered unmappable for purposes of the present reconnaissance study.

The Soyatal formation includes beds overlying limestone conglomerate and massive limestone in the Soyatal antimony mining district. These beds include most of the upper one of three formations mapped at Soyatal by White $(1948$, p. 45$)$, who described the strata as follows: "*** [they] consist of alternating limestone and calcareous 
shale, with the proportion of shale beds increasing upward. A thick succession of higher beds consists predominantly of shale and interbedded sandstone." No formations were named by White; the name Soyatal formation was first proposed by Wilson, Hernández M., and Meave T. (1955).

The type locality of the Mexcala formation is along the Río Mexcala (also known as the Río Balsas) in central Guerrero just east of the bridge on the Mexico City-Acapulco highway, where the unit consists of marine clastic rocks that have a wide range of grain sizes. ${ }^{1}$ The formation has been mapped northward to the latitude of Cuernavaca, Morelos (Fries, 1956), and it appears at intervals as far north as Ixmiquilpan, Hidalgo (Segerstrom, 1956), which is only $80 \mathrm{~km}$ southeast of the Bernal-Jalpan area. The writer feels, therefore, that this same name-Mexcala formation-should be applied to the clastic beds in the upper part of the folded section in the BernalJalpan area.

The following description of beds, beginning at the base of the Soyatal formation, illustrates the gradational nature of the upward change from Soyatal rocks to Mexcala rocks:

1. Thin-bedded flaggy limestone with reddish shale partings forms the base of the Soyatal and Mexcala sections at widely separated localities: $3.5 \mathrm{~km}$ southeast of Ipazotes Grandes, $6 \mathrm{~km}$ southeast of Arquitos, and $1.5 \mathrm{~km}$ northwest of Río Blanco. Near the mouth of Arroyo del Buey, $4.5 \mathrm{~km}$ east-northeast of Peña Blanca, the basal beds consist of three times as much limestone as shale.

2. Several tens of meters higher in the section, the rocks consist of limestone beds $10-30 \mathrm{~cm}$ thick separated by zones of shale of about the same thickness; that is, the volume is about half limestone and half shale. This lithology is seen at various localities, among which are the loop of the Río Extórax about $2 \mathrm{~km}$ northeast of Peña Blanca, along the Extórax $1 \mathrm{~km}$ west of El Timbre, and at the mouth of Arroyo del Carrizalillo, about $8 \mathrm{~km}$ northwest of Peñamiller.

3. One kilometer northeast of Higuerillas, some 50-100 m higher in the section, reddish-stained thin limestone beds occur between thicker, more siliceous strata. About $1 \mathrm{~km}$ southeast of El Buey, between Soyatal and Adjuntas de Higuera, shale or siltstone in zones about $10-30 \mathrm{~cm}$ thick alternates with limestone beds $3-8 \mathrm{~cm}$ thick. In Arroyo del Saucillo, $1.5 \mathrm{~km}$ northeast of Peñamiller, shale in zones $20-60 \mathrm{~cm}$ thick alternates with mudstone beds as much as $30 \mathrm{~cm}$ thick, and in every 2 or 3 meters of the section there is a limestone bed $10-30 \mathrm{~cm}$ thick showing conchoidal fracture.

\footnotetext{
1 Bohnenberger-Thomas, Otto, 1955, Bosquejo geologico a lo largo de la carretera Iquala-Chllpancingo, Estado de Guerrero: Unpublished thesis, Mexico Univ. Nac. Autónoma, Escuela Nac. Ingenieros.
} 
4. At an unknown distance above the base of the section, but probably at least $150 \mathrm{~m}$, the rocks are about 90 percent shale or mudstone and 10 percent limestone; the limestone beds are $2-5 \mathrm{~cm}$ thick. This lithology is seen $1 \mathrm{~km}$ south of Jalpan and at other places in the area.

5 . In the upper part of the section, probably more than $200-300 \mathrm{~m}$ above the base, limestone is rare or absent, and most of the rock is yellow-weathering dark-gray mudstone that appears to be thinly laminated because of fracture cleavage. Much of the mudstone is highly calcareous, but some beds are noncalcareous.

The mudstone is greenish-gray along the road to San Pedro Escanela about $250 \mathrm{~m}$ east of Arquitos and along Arroyo del Portugués about $6.5 \mathrm{~km}$ north-northwest of Peñamiller. The uppermost marine beds in the area are mudstone or shale; in places these beds contain much mica and wood and leaf fragments, as, for example, in a locality about $300 \mathrm{~m}$ east of Arquitos. Graywacke or sandstone, as observed in the El Doctor area (Wilson and others, 1955) and in the southwestern part of the Estado de Hidalgo (Segerstrom, 1956), seem to be absent in the Bernal-Jalpan area, where there is a total of 400-500 $\mathrm{m}$ of Soyatal and Mexcala strata.

Because individual beds locally show little or no lateral change in thickness or lithology and because the total thickness of the beds is doubled within a short distance, the absence of sandstone, graywacke, and conglomerate beds locally is very likely due to erosion of the Mesozoic rocks before deposition of the Tertiary sediments. The Soyatal and Mexcala formations are poorly resistant to erosion; they tend to form badlands topography at the youthful stage of the erosion cycle and gently sloping hills at the mature stage.

No fossils were seen in the Soyatal and Mexcala strata in the area described in this report. Samples of shale for microscopic examination were collected at several places, however. The only fossiliferous sample was found outside the area at a point $18 \mathrm{~km}$ north of Jalpan, where dark-gray calcareous shale in the upper part of the section (Mexcala formation) yielded the pelagic Foraminifera Globotruncana arca (Cushman), in association with several individuals of the benthonic Pulvinulinella texana Cushman. In the Gulf coastal area of the United States, Globotruncana arca is particularly common in rocks of Taylor age, but it also occurs in rocks of early Navarro age. In Mexico this fossil is most common in the Méndez (Taylor) shale, but it is not restricted to that formation, although the types are from the Méndez.

Pulvinulinella texana is known in the Gulf coastal area from rocks of Taylor and early Navarro age (S. K. Fox, oral communication). The age of the Soyatal formation is probably upper Turonian and Coniacian, whereas that of the Mexcala is probably Santonian, Campanian, and early Maestrichtian. 
Apparently because of the ambiguous nature of the Jalpan "Jurassic locality" (p. 33), rocks in the outcrop belt that passes through the town of Jalpan have previously been assigned to the Late Jurassic age. It is true that beds of the Jalpan belt dip under the El Doctor limestone near Puerto Animas, but only because they are on the lower limb of a fold which is overturned toward the east or northeast. The beds of late Cretaceous age that crop out at Jalpan were dated by the microfossils listed in the preceding paragraphs.

TERTIARY SYSTEM

\section{EL MORRO FANGLOMERATE}

Coarse clastic rocks, commonly with a hard matrix of reddish calcareous clay, unconformably overlie the Mexcala and Soyatal, El Doctor, and Las Trancas formations in seven small isolated exposures scattered widely across the Bernal-Jalpan area. Most of the rocks consist of conglomerate or breccia whose cobbles, boulders, and angular slabs were derived from the underlying formations. The rocks are coarsely stratified and are generally flat lying, though their contact with the rocks of Mesozoic age is a surface of great relief. Similar rocks with the same stratigraphic and structural relations crop out over a vast region to the southeast in Hidalgo and in the northeastern part of the Estado de México, where they form the El Morro fanglomerate (Segerstrom, 1956). The rocks here described are believed to be the same. At none of the exposures in the BernalJalpan area does the thickness exceed several tens of meters.

Red conglomerate occurs in the following four localities in the western part of the Bernal-Jalpan area: (a) $4 \mathrm{~km}$ southwest of Tolimán, (b) $4 \mathrm{~km}$ south-southeast of Palmas, (c) Cerro del Palo Alto, and (d) $6 \mathrm{~km}$ north of Peñamiller. The conglomerate directly overlies Soyatal-Mexcala beds in all four outcrop areas and is in turn overlain by volcanic rocks at the first and fourth localities named. The Palo Alto locality, $9 \mathrm{~km}$ northwest of Peñamiller, is a high hilltop covered with horizontally bedded red conglomerate and coarse sandstone extending over an area of about $1.5 \mathrm{sq} \mathrm{km}$. The conglomerate contains well-rounded to subrounded cobbles of limestone, chert, and shale, in a hard calcareous matrix. The locality north of Peñamiller is at the head of the Río del Organo in a $V$-shaped gully, where the conglomerate has initial dips of as much as $25^{\circ}$.

The conglomerate in the El Morro is exposed at three localities in the central part of the Bernal-Jalpan area. Two caplike erosion remnants of red conglomerate lie on opposite sides of a deep valley between Bucareli and Plátano. The conglomerate is poorly stratified and contains boulders of chert-bearing limestone derived from 
the El Doctor limestone, but it directly overlies the Las Trancas formation. The conglomerate is sufficiently cemented to cause the rock to stand in cliffs and pinnacles. The third locality, La Cantera, is $7 \mathrm{~km}$ north-northeast of Bucareli at the top of a broad ridge of El Doctor limestone. At that place gray breccia and sandstone with a well-cemented calcareous matrix occur in thick horizontal beds totaling $25 \mathrm{~m}$ in thickness. Angular fragments of limestone and chert as much as $30 \mathrm{~cm}$ long grade upward into coarse sand-size material composed of angular fragments of limestone, chert, mudstone, and feldspathic (igneous or arkosic?) rock. A breccia bed $7 \mathrm{~m}$ thick at the top of the exposed section contains mostly limestone, but the presence of quartz and biotite grains in highly weathered parts of the breccia indicates that igneous rock (rhyolite?) is a constituent.

The age of the conglomerate in the El Morro in southern Hidalgo is probably late Eocene or early Oligocene (Segerstrom, 1956). Similar rock near the town of Marfil in the Estado de Guanajuato, about $130 \mathrm{~km}$ west of Palmas, has yielded vertebrate remains of late Eocene age (Fries and others, 1955).

\section{UNDIFFERENTIATED VOLCANIC ROCKS}

In the western part of the Bernal-Jalpan area at altitudes greater than $1,700 \mathrm{~m}$ above sea level, lava flows, tuffs, and volcanic breccias disconformably overlie the $\mathrm{El} \mathrm{Morro} \mathrm{fanglomerate} \mathrm{at} \mathrm{two} \mathrm{places,}$ and they overlie the Soyatal and Mexcala formations with great angular unconformity at many places. At a few places in the extreme western part of the area, volcanic rocks directly overlie the El Doctor limestone and the Las Trancas formation. The greatest altitude attained by these rocks within the area here described is 2,300 $\mathrm{m}$ above sea level (Cerro Frontón). These igneous rocks, of highly varied lithology and texture, are probably in large part equivalent to the Pachuca group and Cerezo rhyolite (Segerstrom, 1956), but near Bernal they include later basalts that have not been separated from the older rocks.

Rhyolite is the most abundant volcanic rock in the region. The Estado de Querétaro is widely noted for the opals that have been found in rhyolite flows to the west and southwest of the BernalJalpan area. Flows, breccias, and tuffs occur throughout the volcanic section, but they do not have a definite textural sequence that can be recognized from one outcrop to another.

The following observations show the similarities and the differences in lithology from place to place in the extreme western part of the area, beginning near Bernal at the southwest corner and ending near Palmas in the northwest corner: 
1. Cerro del Picacho, $3 \mathrm{~km}$ west of Bernal, exhibits andesite flow breccia and tuff at the base of the volcanic section succeeded by rhyolite flows intercalated with tuffs.

2. At a point $3 \mathrm{~km}$ east of Bernal, pale reddish-purple rhyolite lava forms the base of the volcanic rocks; farther east the rhyolite is overlain by flaggy-weathering dark-gray basaltic andesite.

3. Five kilometers north of Bernal well-bedded white-weathering and pale yellowish-green-weathering rhyolite(?) tuff is overlain unconformably by reddish rhyolite lava and purple andesite lava.

4. At a locality $4.5 \mathrm{~km}$ southwest of San Pablo, dark-gray biotite dacite is overlain by reddish rhyolite porphyry.

5. Cerro del Pajarito, $3 \mathrm{~km}$ east-southeast of San Pablo, is underlain by rhyolite lava.

6. One kilometer southeast of San Pablo and also $1 \mathrm{~km}$ north of that place, brown-weathering dark-purple andesite lava is exposed.

7. On Cerro del Zacamecate, $5 \mathrm{~km}$ east-southeast of Tolimán, rhyolite tuff and lava overlie rocks of Mesozoic age.

8. Puerto del Jabalí (6 km north-northwest of Tolimán) and Puerto del Roble ( $8 \mathrm{~km}$ south of Palmas) are underlain by reddish-weathering gray rhyolite porphyry that shows prominent spheroidal weathering; this rock directly overlies marine sedimentary rocks of Cretaceous age.

9. Rhyolite lava with very prominent orbicular weathering overlies the Las Trancas formation in an extensive area west of Palmas (fig. 19).

10. At a kaolin quarry $3 \mathrm{~km}$ northwest of Palmas, strongly altered rhyolite lava(?) is overlain by reddish-weathering rhyolite tuff.

Mesa de los Chilitos, $10 \mathrm{~km}$ north of Peñamiller in the northcentral part of the Bernal-Jalpan area, is capped by four lava flows, each about 10-15 m thick, intercalated with tuff. These overlie a sequence of tuff layers about, $200 \mathrm{~m}$ thick on top of the shale and mudstone of the Mexcala formation. The tuff is mainly reddishweathering biotite rhyolite and contains interbeds of breccia and greenish-weathering tuff. Some of the breccia fragments are andesitic, but the matrix is generally rhyolitic. A dark-gray andesite flow $6-8 \mathrm{~m}$ thick occurs about $30 \mathrm{~m}$ above the base of the volcanic section; it is overlain by more tuff. The flows in the upper part of the section consist of vertically jointed red and gray rhyolite.

Other observations concerning the north-central part of the area follow: (a) Cerro de la Cruz, $10 \mathrm{~km}$ northeast of Peñamiller, is underlain by the Mexcala formation and is capped by greenishweathering, dark-gray, fine-grained andesite or dacite; (b) on Cerro del Sombrerete, $2 \mathrm{~km}$ south-southeast of Río Blanco, the Mexcala formation is overlain by strongly porphyritic andesite or dacite; 


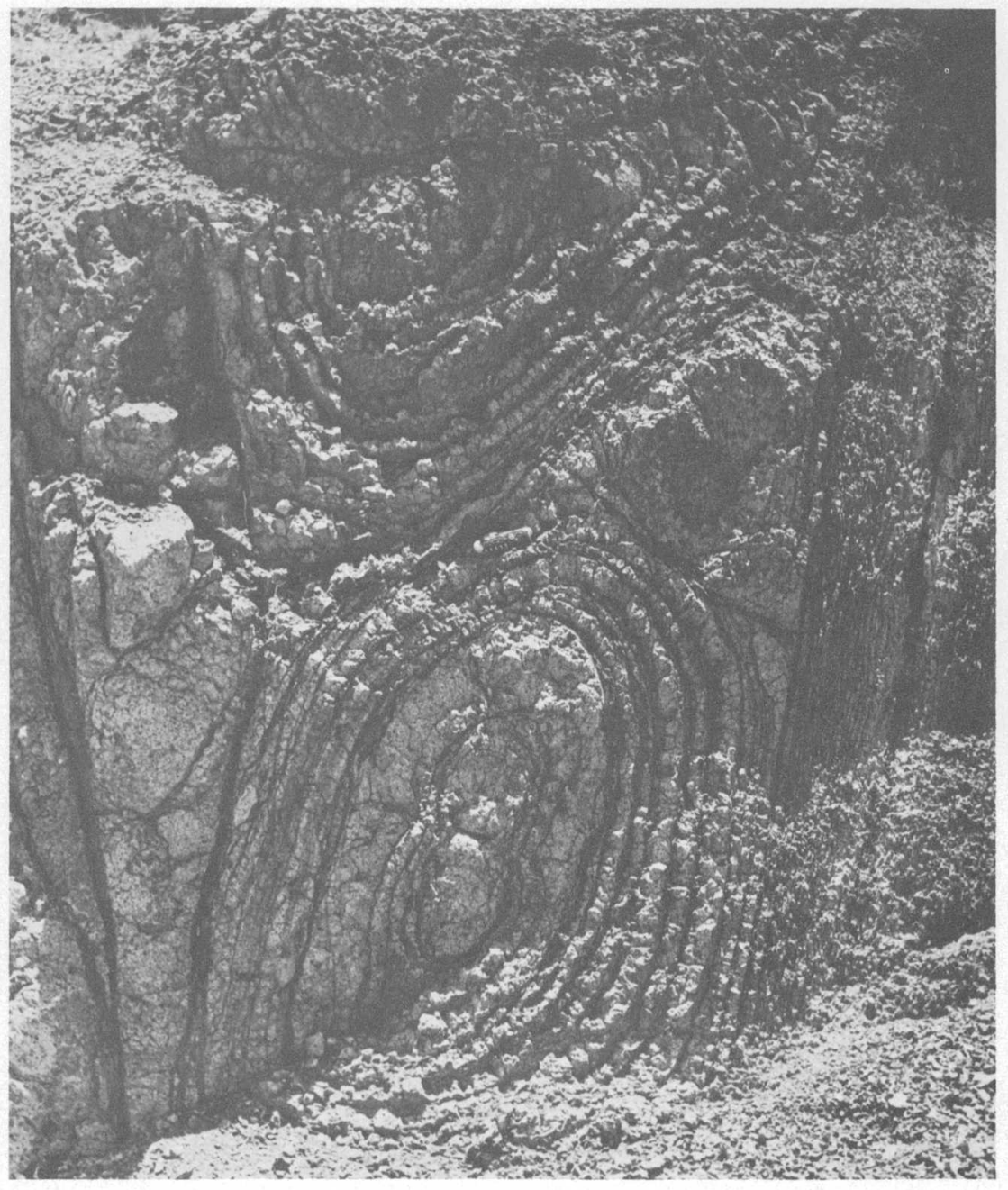

Figure 19.-Orbicular weathering of rhyolite lava, about $2 \mathrm{~km}$ west of Palmas. Knife near center of photograph is about $8 \mathrm{~cm}$ long.

(c) Cerro del Pilón and Cerro de la Tembladera, about $10 \mathrm{~km}$ eastnortheast of Peñamiller, are hills composed of shale and mudstone of the Mexcala formation and capped by reddish-weathering gray fine-grained andesite lava or tuff; (d) on Cerro de los Bernales, 7 $\mathrm{km}$ north-northwest of Pinal de Amoles, a total thickness of $120 \mathrm{~m}$ of poorly bedded gray to light-red hornblende dacite breccia is exposed on top of El Doctor limestone. The series consists of breccia with fragments as much as $1 \mathrm{~m}$ thick; this breccia grades upward into finer clastic material, then abruptly coarsens. Weathering and erosion along very prominent vertical fractures have produced pinnacles in the breccia. 
Disconformities at several places in the group indicate that periods of volcanic accumulation were separated by relatively longer periods of erosion, during which all or part of the older volcanic rocks were eroded before the later rocks were emplaced. Differences in the degree and time of erosion from one exposure of volcanic rocks to another make correlation from place to place difficult. The most common lithologic sequence in the region is andesite or dacite, rhyolite, and basaltic andesite. The sources of the volcanic rocks are largely unknown; two probable extrusive centers are described on pages 53-54.

The age of the volcanic series is somewhat conjectural. Volcanic rocks overlie conglomerate of the El Morro at the head of the Río del Organo $6 \mathrm{~km}$ north of Peñamiller, and so they are younger than the conglomerate of early Tertiary age at that place. However, there are igneous constituents, probably volcanic, in breccia of the El Morro fanglomerate at La Cantera; this fact indicates that the lower part of the volcanic group may be as old as, or perhaps older than, the El Morro. The advanced degree of dissection of the volcanic rocks makes unlikely an age as young as Quaternary. These factors and the similarity of the rocks to those of the Pachuca group and the Cerezo formation, both of whose ages are Oligocene and Miocene, indicate that the volcanic rocks here described are probably mostly of middle Tertiary age.

\section{LATE BASALT}

Gray basalt containing abundant feldspar laths in a fine-grained groundmass caps three buttes and a spur ridge along the Río Extórax at altitudes between 1,500 and $1,600 \mathrm{~m}$. A butte $1 \mathrm{~km}$ east of Peñamiller is capped by $15 \mathrm{~m}$ of basalt which shows conspicuous columnar jointing; a spur ridge $12 \mathrm{~km}$ southeast of Peñamiller is also covered with basalt. Mesa de Ramírez and Mesa del Hormiguero, two low buttes 11-13 km southeast of Pinal de Amoles, are capped by 5-10 m of basalt, on which a reddish-orange soil has formed.' The degree of weathering and erosion suggests that the basalt of these exposures is roughly equivalent to the San Juan group and thus is probably of late Pliocene age.

\section{TERTIARY AND QUATERNARY SYSTEMS}

\section{CLASTIC DEPOSTTS OF LATE CENOzOIC AGE}

Valley-fill and stream-terrace deposits, fanglomerate, and landslide material cover many small areas and six relatively large ones in the Bernal-Jalpan area. Small deposits of unconsolidated clastic material or small rẻmnants of larger deposits are not shown on plate 2. The large deposits and some of the small ones are briefly described in the following paragraphs.

$5864400-61-5$ 
Bernal lies at the north end of a dissected plain of unconsolidated clastic deposits whose top level is about 2,000-2,100 $\mathrm{m}$ above sea level. These deposits, made up mostly of silt and sand deposited in a basin extending to the vicinity of Actopan, about $120 \mathrm{~km}$ southeast of Bernal, are included in the Tarango formation of late Pliocene age. The Tarango formation between Bernal and Actopan is being actively dissected by the Río San Juan and Río Tùla, which join to form the Río Moctezuma at Infiernillo about $45 \mathrm{~km}$ east of Bernal.

San Pablo and Tolimán lie along streams that have eroded an extensive fill deposit of silt, sand, and gravel reaching a maximum altitude of about $1,750 \mathrm{~m}$ above sea level. Silt predominates near the town of San Pablo. Gravel $15 \mathrm{~m}$ thick, made up of fragments of volcanic rocks, limestone, chert, and shale, is exposed at Tierra Volteada $3 \mathrm{~km}$ southwest of Tolimán, and volcanic gravel $20 \mathrm{~m}$ thick is exposed near San Miguelito $5.5 \mathrm{~km}$ southwest of Tolimán. The topographic position and degree of erosion of the San Pablo-Tolimán deposits indicate that their age must be roughly equivalent to that of the Tarango formation.

Palmas and Las Moras, the latter $12.5 \mathrm{~km}$ south-southeast of Palmas, lie on sand and well-rounded gravel that have an exposed thickness of $20 \mathrm{~m}$. The gravel at Palmas consists of volcanic pebbles and cobbles, whereas that at Las Moras consists of both limestone and volcanic rock and contains many large boulders:

Potrerillos, 4-5 km south of Pinal de Amoles, lies in a flat valley drained by a small stream and underlain by fill material that has been deposited on the upstream side of an enormous landslide about $100 \mathrm{~m}$ thick. The landslide, which contains blocks of El Doctor limestone as much as 5-6 m thick, apparently dammed the narrow valley and caused it to be partly filled by silt and sand brought down by the stream.

Tancama lies $7 \mathrm{~km}$ southeast of Jalpan in a narrow valley at the lower end of a gravel-covered plain about $7 \mathrm{~km}$ long and $4 \mathrm{~km}$ in maximum width. This gravel plain is dissected to a depth of more than $50 \mathrm{~m}$ without exposing bedrock, except along the sides.

Gravel terraces, too small to be shown on the map at a 1:100,000 scale, occur along the Río Extórax and some of its tributaries, particularly Arroyo del Saucillo, Arroyo del Pilón, Arroyo del Buey, and other valleys in the country north of the river. On the north bank of the Extórax, $11 \mathrm{~km}$ west of Peñamiller, 10-15 m of wellcemented conglomerate with rounded boulders of limestone and volcanic rocks as much as $1 \mathrm{~m}$ in diameter are exposed (fig. 20). At the mouth of Arroyo del Portugués, $6.5 \mathrm{~km}$ northwest of Peñamiller, gravel banks 6-7 $\mathrm{m}$ high line the watercourse of Arroyo del Saucillo. In Arroyo del Pilón near La Paz, about $5.5 \mathrm{~km}$ east-northeast of 


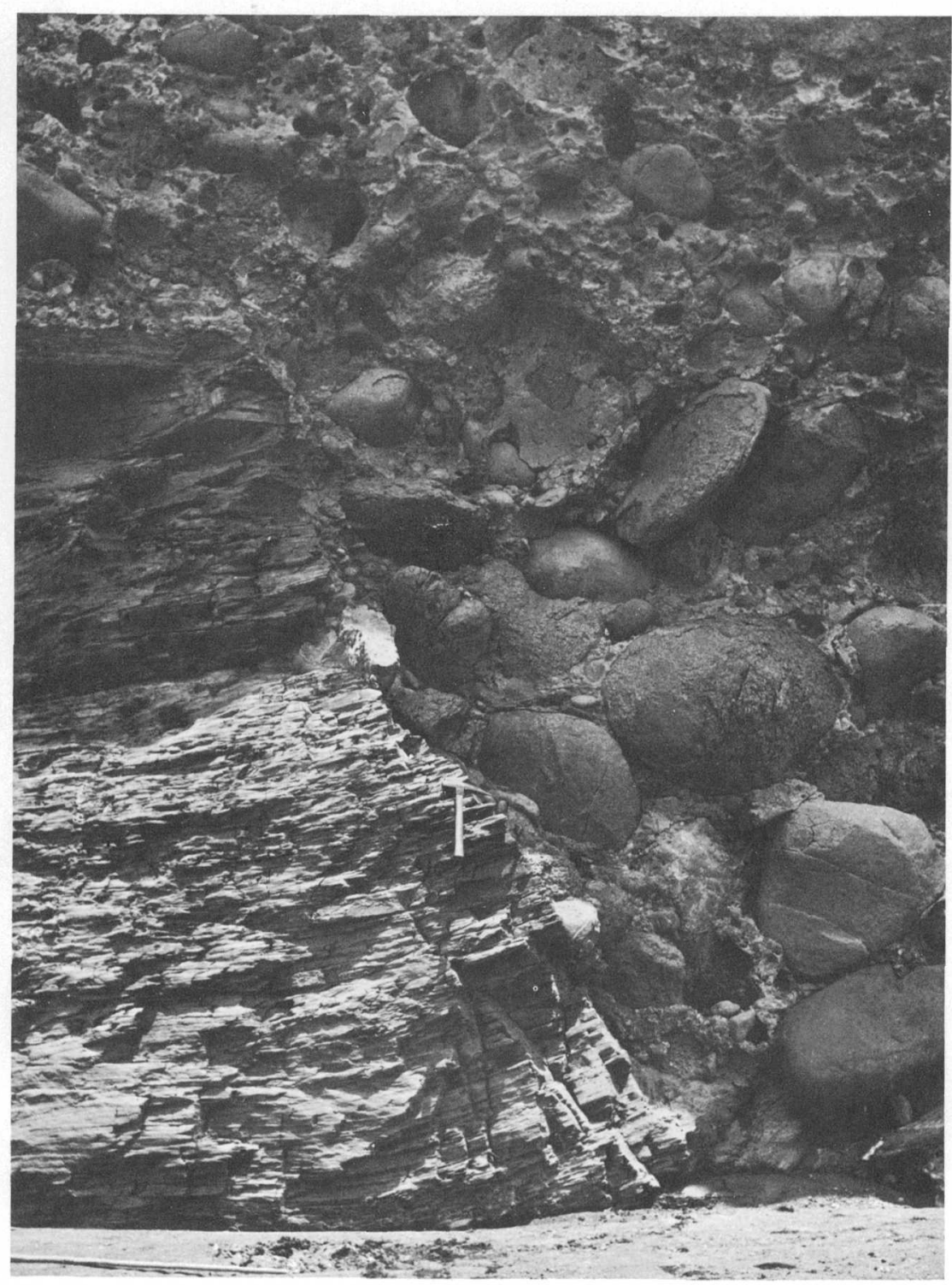

Figure 20.-A bouldery terrace deposit (right) lying against phyllitic shale of the Las Trancas formation (left) along the Río Extorax $11 \mathrm{~km}$ west of Peñamiller.

Peñamiller, there is a bank of well-bedded sand and gravel $10-15 \mathrm{~m}$ thick. At Milpilla, $10.5 \mathrm{~km}$ northwest of Peñamiller, and up the Milpilla valley several kilometers farther, there are numerous terraces which attain maximum elevations of $6-10 \mathrm{~m}$ above the present water course. At El Buey, $13 \mathrm{~km}$ east of Peñamiller, there is a terrace cut in gravel with an exposed thickness of $6-7 \mathrm{~m}$. 
Gravel thinly covers a low ridge of bedrock 20-30 m above the Río Extórax about $1.5 \mathrm{~km}$ northeast of Peña Blanca. Gravel partly covers the knoll on which a mission church at Bucareli stands; the knoll rises about $100 \mathrm{~m}$ above the nearby Extórax. Both of these deposits and the gravel of the high terraces along the Extórax and its main tributaries are probably of Pleistocene age; their topographic position indicates they are younger than the Tarango formation and their degree of erosion suggests they are not modern.

Recent deposits include clastic materials in the valleys at or near present stream levels and alluvial fans formed by tributary flood waters. A high, steep fan at the mouth of a gulch on the south side of the Río Extórax, $1.5 \mathrm{~km}$ southwest of Santa Clara, is large enough to be shown on the map. This fan, formed during a cloudburst, briefly dammed the river and then had its lower edge cut away when the stream reestablished its course.

CALICHE AND RED SOIL

Soils of the Bernal-Jalpan area were studied very little by the author, but some observations were made on their caliche content. Caliche is calcium carbonate that has been leached out of bedrock or detrital material by meteoric water and precipitated by evaporation in the overlying soil zone or on the surface of the bedrock or on detrital fragments. The caliche deposit occurs either as closely spaced laminae lying parallel to the ground surface, or as a cement that binds detrital fragments. Caliche is thickest in the vicinity of Bernal, San Pablo, Tolimán, and Palmas, which are all in the western part of the area. Considerable amounts of caliche are also present on lowlands along the Río Extórax and in the vicinity of Río Blanco and Jalpan. Caliche is almost or completely absent over an area of 200-300 sq km around Pinal de Amoles.

Limestone and other calcareous sedimentary rocks are, of course, more productive of caliche than igneous rocks, but lithology is not the only factor that influences the distribution and thickness of caliche. Caliche is most abundant where the amount of annual rainfall is least ( $350 \mathrm{~mm}$, at Tolimán) and is absent where the rainfall is greatest ( $850 \mathrm{~mm}$, at Pinal de Amoles). Changes of "facies" from calichized soil to noncalichized soil are very sharp at some places and are gradual at others.

The soil at Bernal contains a blanket of caliche 2-3 m thick, which extends east-southeast for a distance of more than $2 \mathrm{~km}$, or nearly to El Jagüey, undiminished in thickness. A mine opening at San Martín Ajuchitlán, $4 \mathrm{~km}$ west-southwest of Bernal, is in 2-3 $\mathrm{m}$ of caliche. Bernal and San Martín are near the southern limit of limestone outcrops of the region. Southward across a broad plain of classic deposits of late Cenozoic age, the caliche blanket gradually 
thins, and in a quarry $8 \mathrm{~km}$ south of Bernal pumiceous sand is overlain by $30 \mathrm{~cm}$ of finely laminated caliche, which is in turn overlain by a surficial layer of dark-brown soil $15 \mathrm{~cm}$ thick.

Peña de Bernal, a hill formed by a rhyolite plug that rises just north of Bernal, is completely without caliche. Calichization of soil that lies over calcareous marine beds occurring in a small window on the top of a ridge of rhyolite tuff $5 \mathrm{~km}$ north-northwest of Bernal has formed a sharply outlined white patch $30 \mathrm{~m}$ in diameter in predominantly brown terrain. A valley extending eastward from Matamba, $6.5 \mathrm{~km}$ north of Tolimán, forms a broad white streak across a brown terrain of Las Trancas gaaywacke. The sharp color contrast is due to calichization of alluvial fill containing boulders shed from the El Doctor limestone, which crops out farther up the valley.

Caliche blankets an area from Jalpan southeast to Jagüey del Rincón, a distance of $12.5 \mathrm{~km}$, yet the watershed divide between Jaguiey del Rincón and Laguna Verde, $1.5 \mathrm{~km}$ to the south, is blanketed only with red soil. The red soil overlies limestone of the Jacala bank, as does the caliche farther north. The divide, which is about 1,250 m above sea level, or $200 \mathrm{~m}$ higher than Jagüey del Rincón, is apparently just high enough to catch the additional rainfall required to change conditions from those conducive to calichization to those conducive to red-soil production.

Red soil is very thick over the El Doctor limestone at the north edge of basalt-capped Mesa de Ramírez about $10 \mathrm{~km}$ southeast of Pinal de Amoles. At that place the red soil over the limestone has a slightly purplish cast, as compared with the slightly orange-red soil over the basalt nearby. The altitude of Mesa de Ramírez is about 1,600 m above sea level, yet $800 \mathrm{~m}$ higher at Pinal de Amoles, -where the climate is more humid, yellowish-brown soil overlies the El Doctor limestone. The red and yellow colors are those of hydrated iron oxides; apparently the state of oxidation and the degree of hydration of the iron that is dominant in the residual soil on the limestone are determined by climate and local topography.

\section{TRA VERTINE}

A great accumulation of travertine, piled layer on layer like shingles, is forming in a spray of calcium carbonate-saturated meteoric water on a cliff of $\mathrm{El}$ Doctor limestone about $5 \mathrm{~km}$ west of Las Medias (fig. 21). Stalactites and stalagmites have formed on the northeast slope of Arroyo del Tránsito on the side of a precipice 25 $\mathrm{m}$ high about $4 \mathrm{~km}$ east-northeast of Río Blanco. The travertine serves as cement for limestone breccia at that place. Three or four travertine bodies, each several hundred meters long, are festooned along the south slope of Arroyo de Higuera, about $4 \mathrm{~km}$ southeast of 


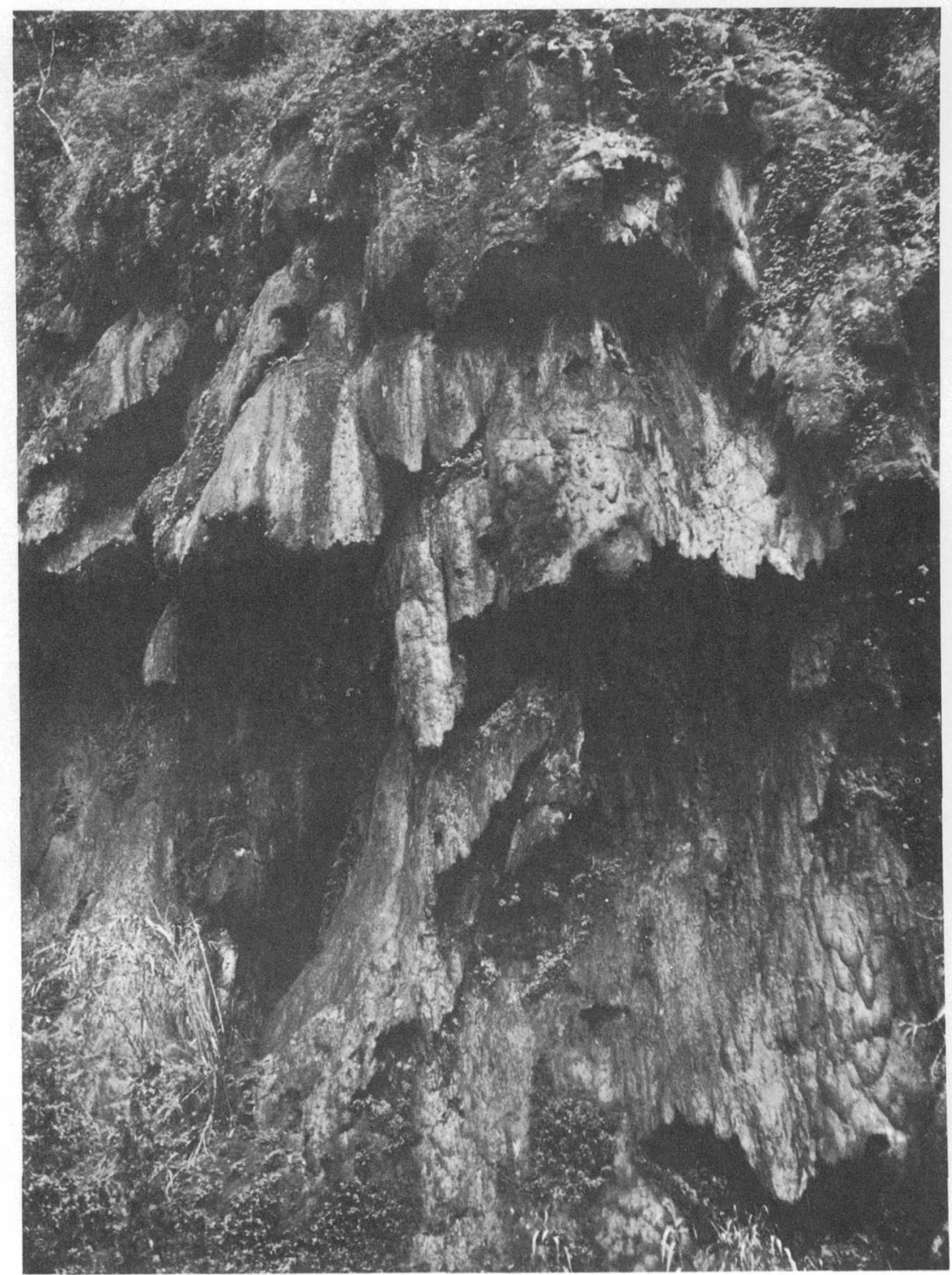

Figure 21.-Travertine deposits on wall of canyon of the Río Extorax, about $5 \mathrm{~km}$ west of Las Medias.

Peña Blanca. Much of the drainage of the high, relatively humid limestone country to the south is underground. However, much of the water comes to the surface at the contact of the El Doctor limestone with the underlying less permeable Las Trancas formation along the base of the steep south slope of the arroyo. Thick masses of travertine have been deposited at this place. 


\section{INTRUSI VE ROCKS}

Both porphyritic and equigranular igneous rocks occur among the intrusive bodies that crop out in the Bernal-Jalpan area. Quartzbearing rocks, as well as those without quartz, are represented in rocks of both textures. The porphyritic intrusive rocks are indistinguishable in hand specimen from extrusive rocks; their intrusive nature is inferred from the shape of the igneous body and its relation to adjacent rocks. At least two of the porphyritic intrusive bodies appear to have served as feeders to extrusive bodies.

\section{PORPHYRITIC INTRUSIVE ROCKS}

An andesitic or dacitic plug of roughly circular shape is in the vicinity of the Poder de Dios mine, $5 \mathrm{~km}$ north of Pinal de Amoles. This plug is $800 \mathrm{~m}$ in diameter at the surface and forms a topographic low surrounded by limestone mountains. The rock is gray and finely porphyritic and contains small angular inclusions of limestone in great number; the largest observed inclusion is $15 \mathrm{~cm}$ long. The plug may well be the source of hornblende dacite porphyry breccia which lies in horizontal beds $1.5 \mathrm{~km}$ to the northwest.

Andesite and dacite(?) dikes are widely distributed in the western part of the area, a few occur in the central part, and one dacite(?) dike crops out in the eastern part. A few sills were observed in the western part; for example, a hornblende andesite sill $1.5 \mathrm{~m}$ thick crops out along Arroyo de Milpilla, $7 \mathrm{~km}$ northeast of Peñamiller. The sills are not shown on the map. Dikes are plotted on the map only where they crop out in areas of sedimentary rocks, and even there only a few of the largest ones are shown. Widths of the dikes had to be exaggerated in order to make them plottable.

A dike of fine-grained andesite about $30 \mathrm{~m}$ wide, about $1.5 \mathrm{~km}$ northeast of Pinal de Amoles, crosses the road to Jalpan and appears to cut off an ore body to the northwest.

At Tejamanil, $3 \mathrm{~km}$ southwest of Pinal de Amoles, there is a dike of hornblende andesite porphyry $60 \mathrm{~m}$ wide. Another hornblende andesite dike $5 \mathrm{~m}$ wide is visible at three places along the BernalPinal de Amoles highway between Camargo and El Madroño. A dike of dark-gray andesite $3 \mathrm{~m}$ wide, with hornblende phenocrysts as much as $8 \mathrm{~mm}$ long, crops out along the Río Extórax $2 \mathrm{~km}$ northeast of Peña Blanca. Greenish-gray (propylitized?) hornblende andesite intrusive rock crops out for a distance of $40 \mathrm{~m}$ along the east bank of the Extórax a short distance north of Adjuntas de Higuera. The ensternmost exposure of intrusive rock in the entire area is a dike of pale-green-weathering gray dacite(?) with quartz phenocrysts; the dike, which is $50 \mathrm{~m}$ wide, cuts the Las Trancas 
formation at the mouth of Arroyo del Limón, $2 \mathrm{~km}$ northeast of Las Medias.

The most conspicuous porphyritic intrusive body in the BernalJalpan area is the one whose surface expression is Peña de Bernal. The Peña is a pinnacle about $500 \mathrm{~m}$ in diameter which rises about $350 \mathrm{~m}$ above the town of Bernal. A broad ridge extending $2 \mathrm{~km}$ to the northeast and another ridge extending $500 \mathrm{~m}$ to the west are the topographic expression of radial dikes that extend outward from the central plug (fig. 22). The rock is fine-grained light-gray biotite rhyolite, massive in some parts and with strong flow structure in other parts. Well-defined fractures, $15-25 \mathrm{~cm}$ apart, follow the flow structure in places. Much of the flow structure is nearly vertical, but the dips are irregular in detail; they tend to be toward the center and thus impart a funnellike structure to the central mass. In its more massive parts the rhyolite is characterized by conspicuous spheroidal weathering (fig. 23). Cupolalike masses of the rhyolite lie to the north and to the southwest of the plug. A roof pendant of pre-Las Trancas phyllite lies between the Peña and the northern cupola. The southwestern cupola does not crop out, but it is cut in the underground workings of a large mine at San Martín Ajuchitlán. Peña de Bernal is probably the eroded core of an eruptive body.

A prominent rhyolite dike about $10 \mathrm{~m}$ wide crops out $1.5 \mathrm{~km}$ northwest of Curva Grande, or $7 \mathrm{~km}$ north-northeast of Pinal de Amoles. Another rhyolite dike about $40 \mathrm{~m}$ wide occurs along the El

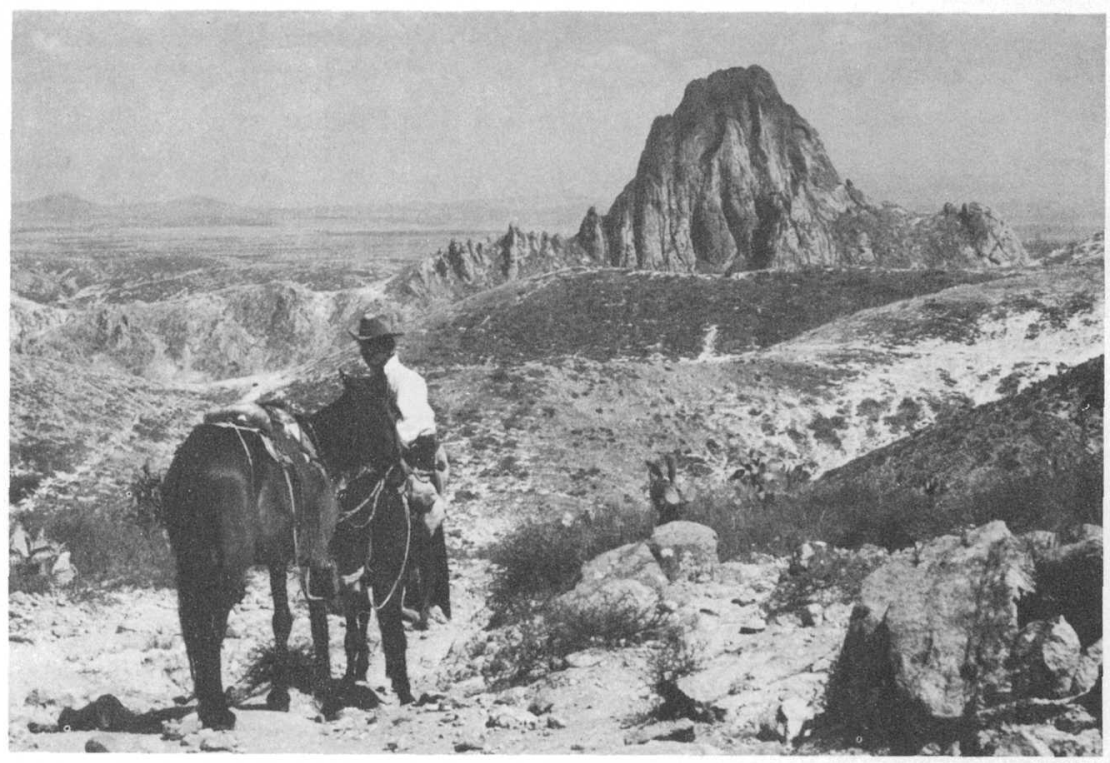

FigURE 22.-Peña de Bernal as seen from the northwest, showing radial dikes. 


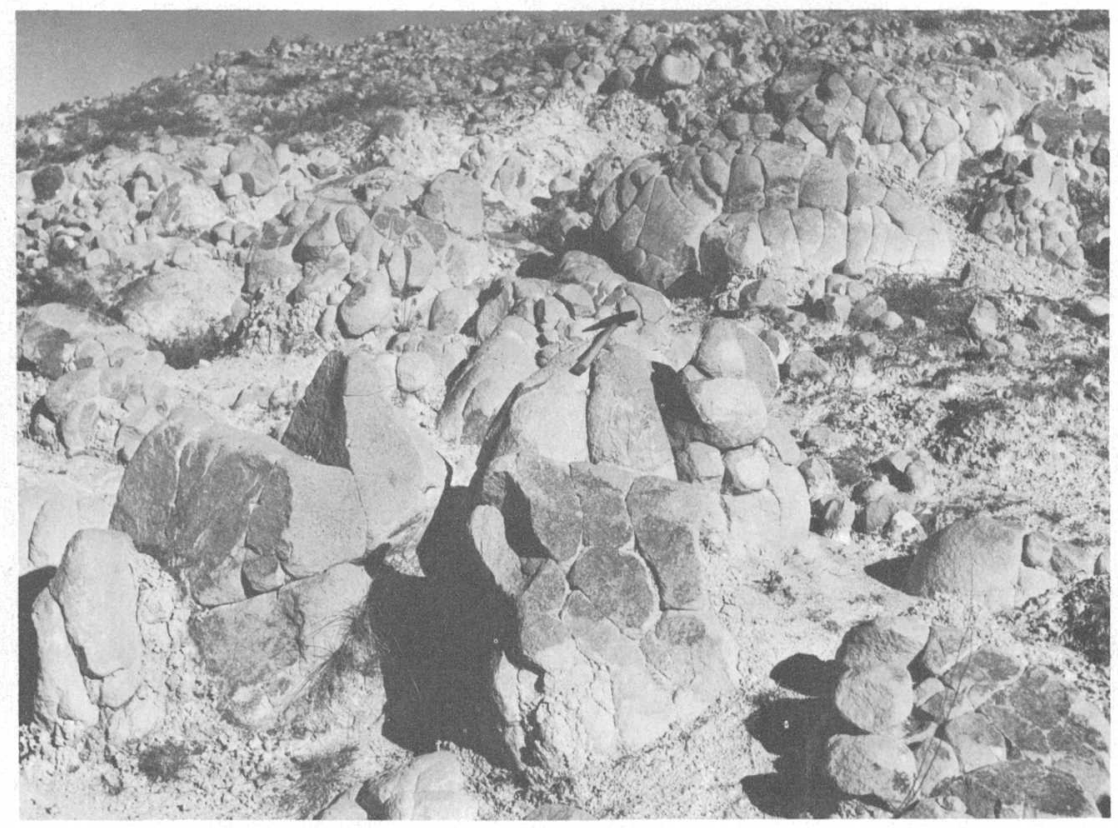

Figure 23.-General aspect of weathered rhyolite, northwest of San Antonio de la Cal.

Raizal fault, about $1 \mathrm{~km}$ east of Soyatal. Several smaller rhyolite intrusive bodies are exposed at short distances south of the town of Bucareli.

The highway between Arquitos and San Pedro Escanela crosses a dark-gray hornblende diabase(?) or lamprophyre(?) dike $4.5 \mathrm{~km}$ east-northeast of Pinal de Amoles. A dike of amygdaloidal basalt crops out about $2 \mathrm{~km}$ west of Soyatal (White, 1948, p. 48).

\section{EQUIGRANULAR INTRUSIVE ROCKS}

An irregular-shaped stock with a maximum outcrop width of about $2.5 \mathrm{~km}$ intrudes the $\mathrm{El}$ Doctor limestone southeast of Río Blanco. The rock in the western part of the intrusive mass is light gray, massive, equigranular, and of medium grain size $(1-5 \mathrm{~mm})$; it contains many angular inclusions of dark-gray massive rock of the same texture, as well as a few scattered inclusions of dark-gray banded hornfels (?). The rock contains (in order of abundance) crystals of twinned feldspar, quartz, and biotite, and has the megascopic appearance of quartz diorite. A more dioritic rock, resembling the inclusions in the quartz diorite, seems to make up two northerly prongs of the intrusive mass. Along the west contact of the stock the quartz diorite breaks into enormous blocks $6-10 \mathrm{~m}$ in width. 
A roughly triangular-shaped stock with a maximum outcrop width of $3 \mathrm{~km}$ intrudes the EI Doctor limestone east and southeast of Pinal de Amoles. Biotite diorite, medium- to dark-gray and mediumgrained, is exposed along the west and south edges, but mediumgrained rock inside the stock, of lighter color and containing abundant quartz crystals, is probably quartz diorite. Fine-grained white crystalline rock occurs sparsely inside the stock, but exposures are so small and so weathered that it could not be determined if they are aplite dikes. Outcrops near the north and east edges of the stock are also so deeply weathered that they could be identified only as being an equigranular igneous rock.

The stocks near Río Blanco and Pinal de Amoles are almost exactly alined with a diorite stock that intrudes the El Doctor limestone and the Soyatal formation at Encarnacion-San José del Oro, $50 \mathrm{~km} \mathrm{S.} 58^{\circ}$ E. of Pinal de Amoles, and with the Xichú mining district, $55 \mathrm{~km} \mathrm{~N}$. $56^{\circ} \mathrm{W}$. of Pinal de Amoles. Río Blanco is about $13 \mathrm{~km} \mathrm{~N} .55^{\circ} \mathrm{W}$. of Pinal de Amoles. The only other stock that crops out in the region is located $42 \mathrm{~km} \mathrm{S.} 26^{\circ}$ E. of Pinal de Amoles, a short distance north of Zimapán. The stock near Zimapán ranges in composition from monzonite to diorite, and intrudes all the Cretaceous and Tertiary formations in the district (Simons and Mapes, 1956, p. 21-22).

\section{CONTACT-METAMORPHIC ROCKS}

Zones on either side of the fine-grained andesite dike that lies outside the northwest corner of the stock near Pinal de Amoles show an outward gradation within a space of $10 \mathrm{~m}$ from garnetiferous tactite through coarse-grained marble to slightly recrystallized El Doctor limestone. A broader tactite zone, at least $40 \mathrm{~m}$ wide, occurs about $1 \mathrm{~km}$ southeast of Pinal de Amoles between the stock and a narrow prong of diorite that juts out from the west edge of the main intrusive body. A reentrant or roof pendant of chert-bearing El Doctor limestone about $200 \mathrm{~m}$ wide, $2 \mathrm{~km}$ southeast of Pinal de Amoles, has been metamorphosed along the igneous contact into white sugary-weathering marble containing coarse-grained tremolite and lenses or thin beds of green silicated chert; the green members stand out from outcrop surfaces, owing to their greater resistance to weathering. Massive light-gray fine-grained tactite forms a sharply defined zone along the east edge of the Río Blanco stock, at the Cueva del Oro mine. The only known place in the area where contact-metamorphic rock occurs adjacent to porphyritic intrusive rocks is in the San Martín Ajuchitlán mine, $4 \mathrm{~km}$ southwest of Bernal. At that place, pale-gray tactite occupies a zone $25-40 \mathrm{~m}$ wide between intrusive rhyolite and the country rock of shaly limestone. 


\section{STRUCTURE}

The Cretaceous, Jurassic, and older(?) rocks of the region have been thrown into numerous folds that trend from northwest to north. Boudinage, fracture cleavage, and minor thrust faults are related to the folds. Beds are locally deformed by doming in the vicinity of Bernal.

\section{FOLDS}

The major structural features of the area from west to east are: El Chilar anticline, San Lorenzo syncline, Pingüical anticline, and Jalpan syncline. The two anticlines and two synclines are large complex folds $15-30 \mathrm{~km}$ wide. Some small folds are in themselves major features as compared with innumerable still smaller folds that exist, but they cannot be shown on a small-scale map; for example, the Soyatal mining district is represented on the map at a $1: 100,000$ scale as lying in a lesser syncline, and yet a previously published map of the Soyatal district at a 1:2,500 scale shows the axes of at least 20 folds in the same synclinal area, many of which contain a large number of minor folds (White, 1948). The task of choosing the strike and dip measurements that best express the major structural features was difficult. Much of the tracing of axial planes was, therefore, guided purely by outcrop patterns. The two major anticlines are described in detail in the following paragraphs. A few structural characteristics of axial areas of the two intervening synclines are also described.

The El Chilar anticline, named for a village $5 \mathrm{~km}$ northeast of Tolimán on the Río Tolimán extends across the western part of the area and raises the oldest rocks in that region. The axial plane of this major complex fold is almost vertical in the area northwest of El Chilar, but it is inclined in the area southeast of El Chilar as a result of the fold's being overturned toward the northeast. The highest point along the road between San Pablo and Higuerillas is at the crest of the major fold. Only the northeast limb is well exposed; the southwest limb is overlapped by unfolded rocks of Cenozoic age.

The northeast limb of the El Chilar anticline is deformed for about $5 \mathrm{~km}$ west of Higuerillas into small recumbent folds, one fold lying above another and each fold extending farther east than the next higher one. The El Doctor limestone, which is only several tens of meters thick here, is involved in the folding. It presents relatively flat, terracelike outcrops at three distinct levels, yet much of the underlying Las Trancas formation is steeply dipping. Apparently the axial planes of smaller folds flatten upward through the section, for there is no evidence of an angular unconformity. At other places the dips of beds in the lower part of the El Chilar 
anticline are likewise much steeper than in the upper part. In the area northwest of El Chilar, the intense deformation of the Las Trancas formation and the older rocks tends to die out upward; there the massive El Doctor formation is more than $150 \mathrm{~m}$ thick and is also flatlying, but it does not seem to be recumbently folded. Tight chevron folds overturned toward the east occur in the Las Trancas formation $6 \mathrm{~km}$ south of Higuerillas (fig. 24).

An overturned minor anticline northwest of Peñamiller, a part of the northeast limb of the El Chilar anticline, is incompletely breached by erosion, so that part of a roof of El Doctor limestone remains in the middle of a $10-\mathrm{km}$ segment but is absent on both sides. This incomplete breaching has twice split the El Doctor outcrop area in two parts. The plunges of nearby small folds suggest that the anticlinal axis is doubly plunging in this sector, and thus the double plunge may have produced the saglike structural feature in the axial area where the limestone roof remains.

The Pingüical anticline is named for Cerro del Pingüical, a mountain $6.5 \mathrm{~km}$ northwest of Pinal de Amoles. Cerro del Pingüical, $3,191 \mathrm{~m}$ above sea level, is higher than any other mountain eastward to the Gulf of Mexico and northward for hundreds of kilometers along the Sierra Madre Oriental. The Pingüical anticline exhibits an amplitude of folding of no less than $2,000 \mathrm{~m}$, for it rises nearly

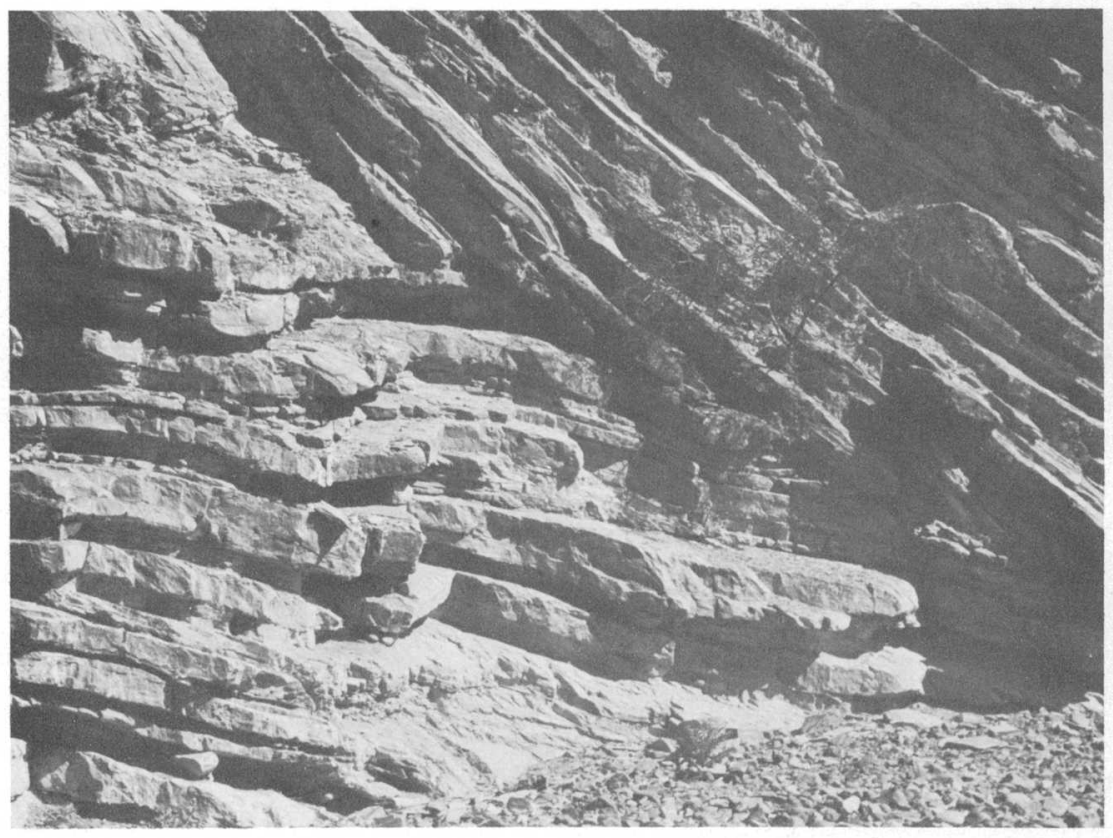

Figure 24.-Tight chevron fold in the Las Trancas formation $6 \mathrm{~km}$ south of Higuerillas, as seen from the north. 
that high above the shale lowland formed by the San Lorenzo syncline to the west, where the top of the El Doctor limestone is probably hundreds of meters below the surface. The virtually unbreached Pingüical anticline differs notably from the El Chilar anticline, which has been so deeply eroded that little more than its core remains. Most of the lofty Pingüical anticline is thickly covered by a plicated canopy of El Doctor limestone, which is itself covered in several places by the Soyatal and Mexcala formations or by volcanic rocks. The Las Trancas formation is exposed where a few windows provide openings in the roof. The roof is also pierced by intrusive bodies of small areal extent.

A group of small folds on the southwest limb of the complex Pingüical anticline shows a sharp change in trend from N. $30^{\circ}$ W. to N. $70^{\circ} \mathrm{W}$. in the vicinity of the Soyatal mining district. Traces of axial planes in small folds on the northeast limb of the anticline show a pronounced indentation toward the southwest, where they cross the deep canyon of the Río Extórax. Inasmuch as the axial planes dip to the west, the apparent indentation along the Río Extórax is probably due to topographic structure rather than to actual curving of the planes.

Although the principal fold of the complex Pinguiical anticline (the fold with the highest crest) has limbs that dip in opposite directions, the limbs themselves are, in places, thrown into multiple overturned or recumbent positions. Along the road that leads to Pinal de Amoles from the west and toward Jalpan to the east, the following structural features are seen: an extensive dip slope to the north of the road between Camargo and El Madroño; a giant drag fold outlined by a 3-m limestone marker bed west of the steeply ascending road between El Madroño and Puerto Velásquez; overturned chevron folds at the crest of the Pinguiical anticline near Puerto del Cielo, extending with many repetitions across the northeast limb through Pinal de Amoles nearly to Arquitos; a shale synclinal member of the major anticline for several kilometers northeast of Arquitos; a breached smaller anticline along the steeply descending Cuesta de Huasmazontla with El Doctor limestone on its limbs and with phyllitic beds of the Las Trancas formation in the middle.

Recumbent folds with nearly parallel limbs and with a depth equal to their width appear to produce a six-fold repetition of beds of the El Doctor limestone at its exposure in a cliff 150-200 m high between Puerto del Jaboncillo and El Moral about $5 \mathrm{~km}$ southwest of Pinal de Amoles. Very extensive recumbent folding occurs on an outcrop scale between Bucareli and Adjuntas de Higuera. Axial planes of flatly overturned, nearly recumbent folds dip eastward at 
a place along the Río Extórax about $4.5 \mathrm{~km}$ south-southwest of Bucareli and westward about $1 \mathrm{~km}$ west of that place. The principal axis of the Pinguiical anticline is between those two places. Numerous chevron folds are exposed in the El Doctor limestone both downstream and upstream from Las Medias (fig. 25.)

Smaller folds on the plicated limbs of the major structure are doubly plunging locally; this double plunging produces an alternately concave and convex profile along some fold axes. The steepest axial plunge observed in these small folds of the Pingüical anticline is $15^{\circ}$ (about three-quarters of a kilometer west of Arquitos and at La Ventana).

The San Lorenzo syncline, named for a village on the Río Extórax $5.5 \mathrm{~km}$ east-southeast of Peñamiller, lies between the El Chilar and Pingüical anticlines and forms a conspicuous low in the regional topography. The Soyatal and Mexcala formations are exposed throughout the synclinal lowland, except where they are capped by rocks of Cenozoic age. The axial plane of the fold that forms the lowest trough of the San Lorenzo syncline is overturned toward the east or northeast. Member folds of the complex major syncline locally converge toward the southwest, as indicated by widening of the synclinal lowland from south to north. Dips of beds and axial planes of minor folds in the San Lorenzo syncline are almost every.

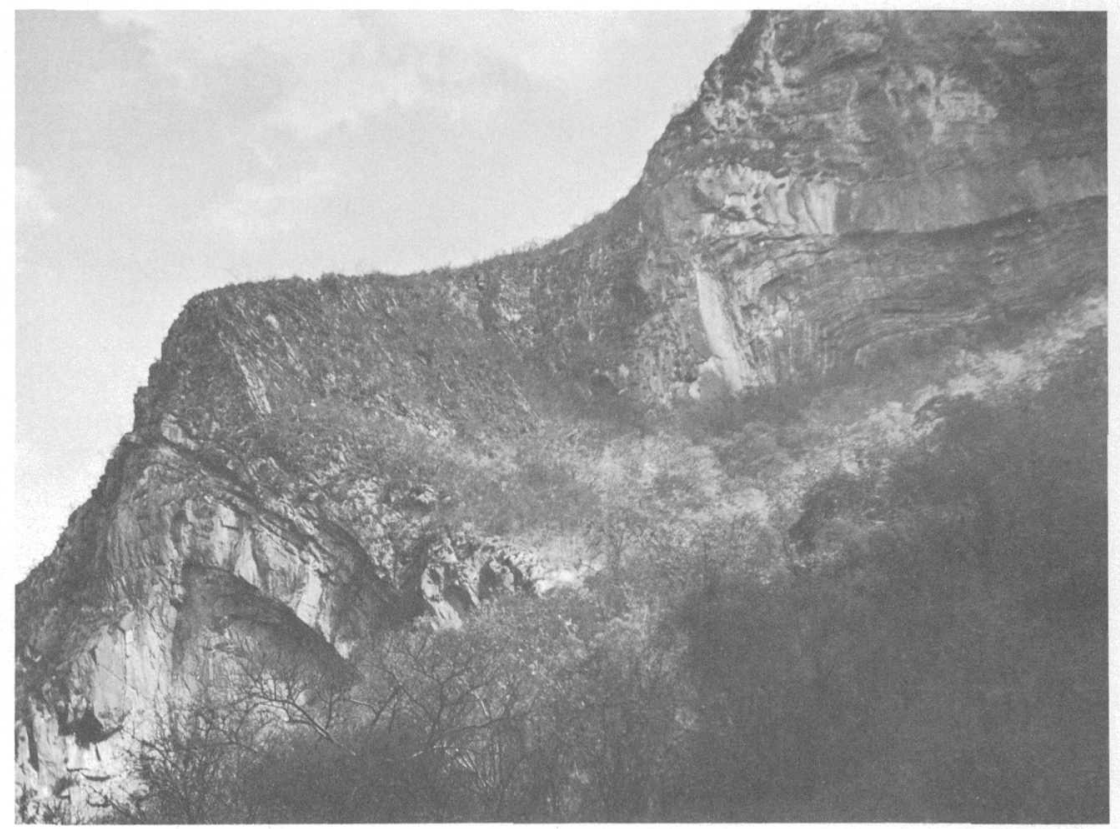

Figure 25. Chevron folds in the El Doctor limestone. The view is southeast, in the eanyon between Bucareli and Las Medias. 
where toward the west or southwest and are generally steeper than $30^{\circ}$ (fig. 26). Recumbent folds are rarely seen in outcrops. The axis of a minor fold exposed along the Río del Organo $7 \mathrm{~km}$ north of Peñamiller has a measured plunge of $18^{\circ}$ to the northwest.

A smaller anticline on the west limb of the San Lorenzo syncline forms a ridge of Soyatal and Mexcala rocks north of Higuerillas.

The San Lorenzo syncline dies out a few kilometers north of the state boundary between Querétaro and Guanajuato, but it is traceable for many kilometers southeast of the area here described, even where

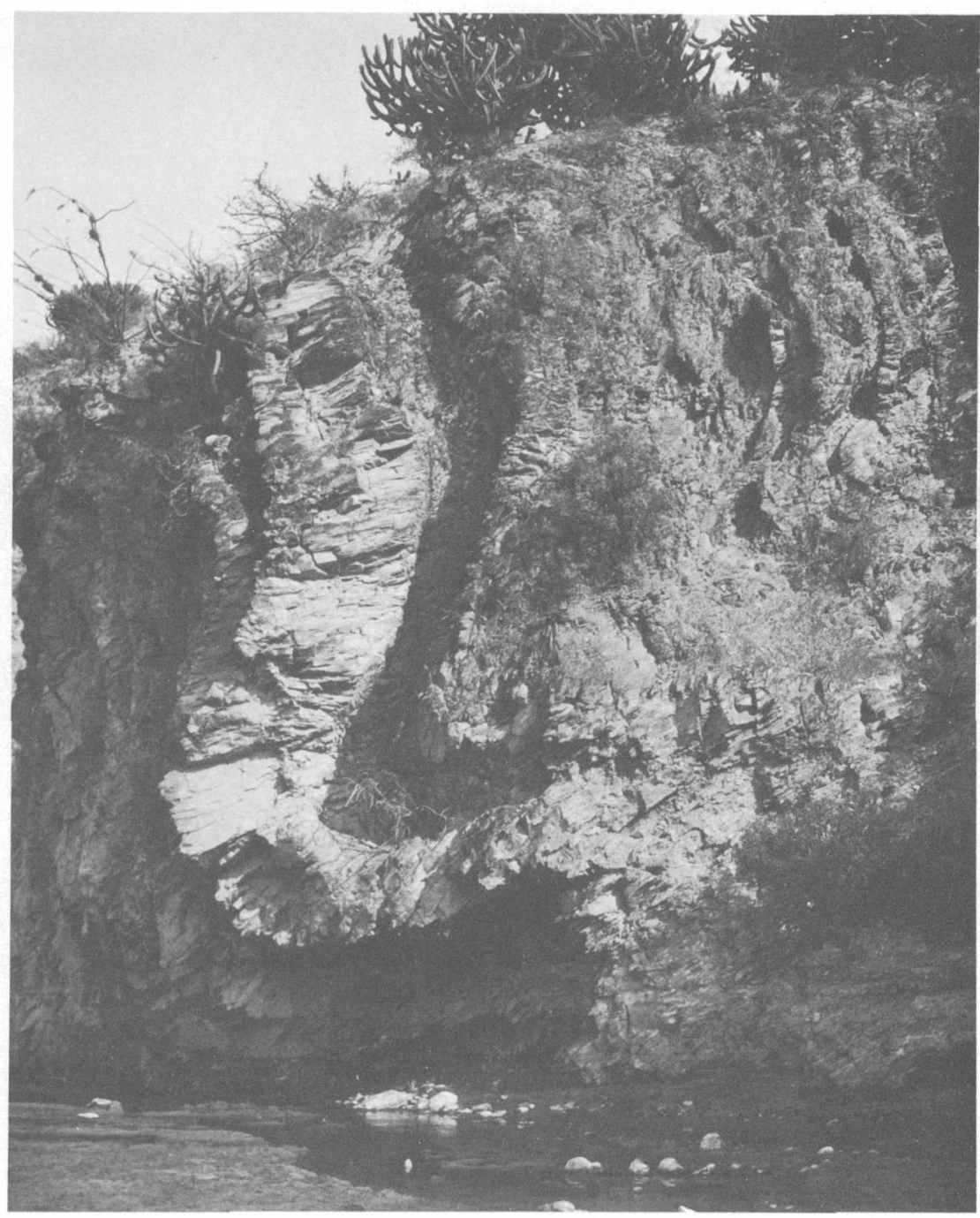

Figure 26.-Small fold on a limb of the San Lorenzo syncline on the north side of the bed of the Río Extórax, a short distance west of the village of San Lorenzo. 
it is largely covered by deposits of Cenozoic age. The syncline can be traced to the Río Jilotepec near the north edge of the Mexico City basin, $120 \mathrm{~km}$ from the village of San Lorenzo.

The Jalpan syncline, named for the town of Jalpan, lies between the Pinguiical anticline and the Jacala bank in the eastern part of the area of plate 2. The Soyatal and Mexcala formations are exposed in the axial zone of the syncline for many kilometers northnorthwest of Jalpan and for $10 \mathrm{~km}$ south of that place; they form a topographic low, but the El Doctor limestone crops out along the axial zone farther south in a highland which is deeply dissected by the Río Extórax. The syncline plunges to the north, where the shale lowland is replaced by the limestone highland.

Dissection of the highland is so deep that the El Doctor limestone is breached on either side of the axial zone of the syncline and the breaching exposes the Las Trancas formation. Where the Río Extórax crosses the zone, the topographic expression of the syncline is reversed from valley to ridge; the river passes through the ridge in a narrow canyon cut in the El Doctor limestone between relatively broad shale valleys that have been cut in the older Las Trancas formation.

A distinguishing feature of the Jalpan syncline is its trend, which is much more northerly than that of other folds in the area. The regional northwesterly trend of the folds has evidently been deflected locally by the Jacala bank, for the Jalpan syncline is roughly parallel to the west edge of the bank.

The Jalpan syncline, split by a south-plunging smaller anticline in the El Doctor limestone, forms a double outcrop of Soyatal and Mexcala rocks that can be traced almost to Cárdenas, $90 \mathrm{~km}$ northnorthwest of Jalpan. The syncline extends a relatively short distance southeast of Jalpan and dies out near the south edge of the area of plate 2 .

The folding was likely a part of the Laramide orogeny, which in the general region of Bernal and Jalpan is probably of middle Eocene age. The folding was produced by a compressive force couple whose direction of major force, at right angles to the trend of fold axes, was east-northeast, for the folds tend to be overturned in that direction.

\section{BOUDINAGE}

Boudinage, "a sausage structure" (Cloos, 1947, p. 626), is common in the Las Trancas formation, where relatively competent limestone beds alternate with less competent phyllite, shale, or mudstone; it is less common in the El Doctor unit, where medium to thick limestone beds alternate with thin limestone beds, and it is absent in younger 
formations. Boudinage of chert beds in the El Doctor limestone has been described for the Zimapán mining district (Simons and Mapes, 1956, p. 31-32). The competent limestone beds of the Las Trancas formation are cut at many places by fractures that trend roughly perpendicular to the direction of the dip. Where fragments formed by the fractures have separated, incompetent phyllite or thin-bedded limestone with shale partings (fig. 27) has flowed into the gap (see also Cloos, 1946 , p. 9). On the limbs of recumbent folds along the Río Extórax, separated fragments have rotated $20^{\circ}-30^{\circ}$ and have then been rejoined by calcite veins; other fragments have been so widely separated from the original bed that they occur as isolated spindle-shaped masses, as seen in vertical section (fig. 28).

The boudinage probably was formed at the time of folding. Competent beds lying between incompetent beds on the limbs of folds were fractured and pulled apart by stretching of the limbs during the folding. The same compressive force couple that overturned many folds to the east-northeast rotated fragments of the fractured beds in the same direction. Rotation of chert fragments was toward the northeast also in the Zimapán district (Simons and Mapes, 1956, p. 32).

The absence of boudinage in the Soyatal and Mexcala formations may be at least partly explained by the fact that a lighter load of

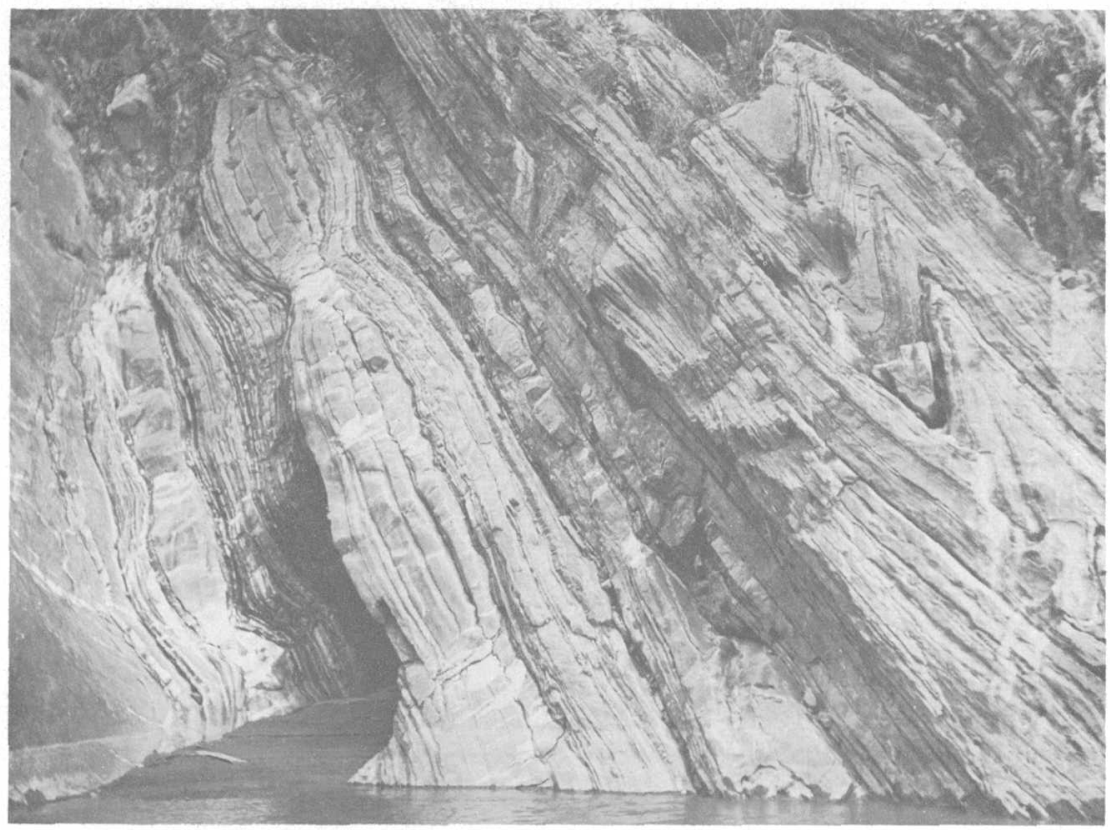

Figure 27.-Boudinage and chevron folds in the El Doctor limestone, along the Río Extórax between Bucareli and Las Medias. 


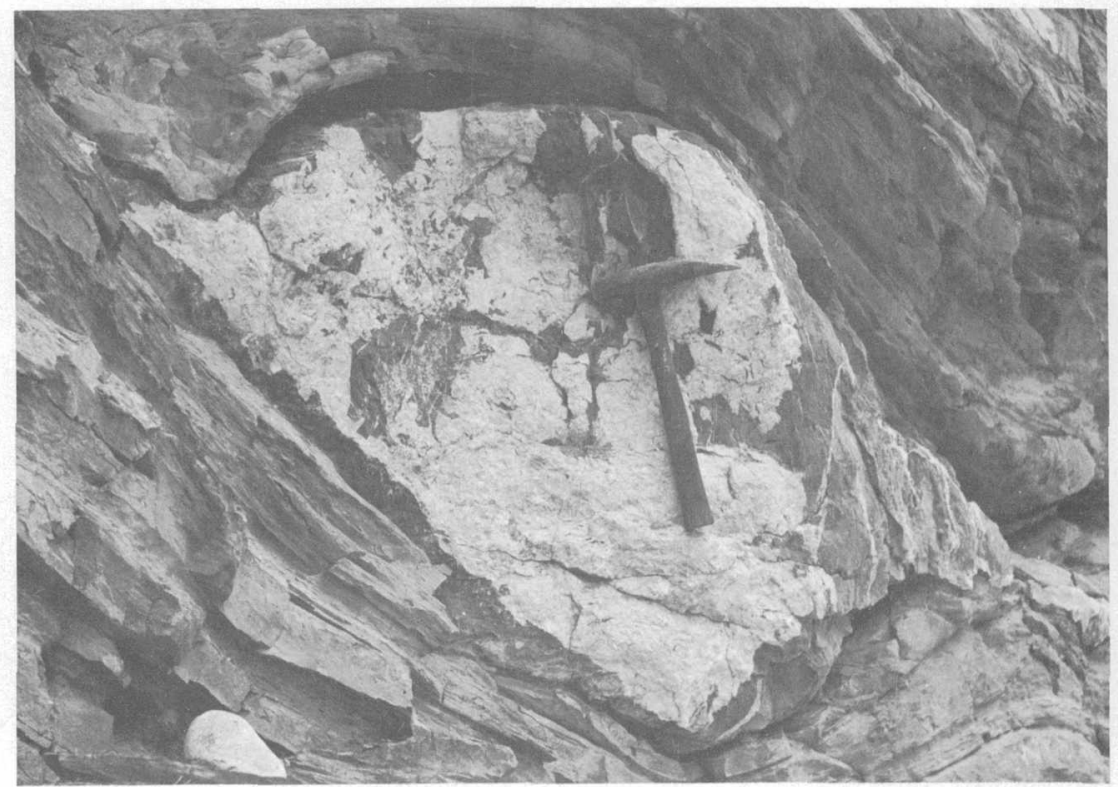

FigURE 28.-Isolated, spindle-shaped mass of limestone enclosed in phyllite.

sediments overlay those formations during the Laramide orogeny; perhaps the load was insufficient to cause the plastic flowage of incompetent beds that was required to fill gaps between the fragments of competent beds.

\section{FRACTURE CLEAVAGE}

Fracture cleavage consisting of closely spaced parallel fractures is very common in the Soyatal and Mexcala formations; it gives those units the aspect of shale, even where bedding is thick (fig. 29). Fracture cleavage is fairly common in the Las Trancas formation, but it occurs at only a few places in the El Doctor limestone. The fractures cut the bedding at all inclinations from almost parallel to right angles, but there is no megascopically observable displacement at most places. Where beds in a fold are all of the same lithology, which may be either clastic or limestone, the cleavage is commonly subparallel to the axial plane of the fold. Where the beds alternate from shale, mudstone, or phyllite to limestone, the dip of cleavage changes abruptly from approximately parallel to the axial plane in the incompetent argillaceous rock to approximately normal to a limb of the fold in the more competent limestone. Fractures are less closely spaced in limestone than in argillaceous rock.

Fracture cleavage has an axial plane position with respect to minor crinkles on the bedding at some localities. Crinkles on the under- 


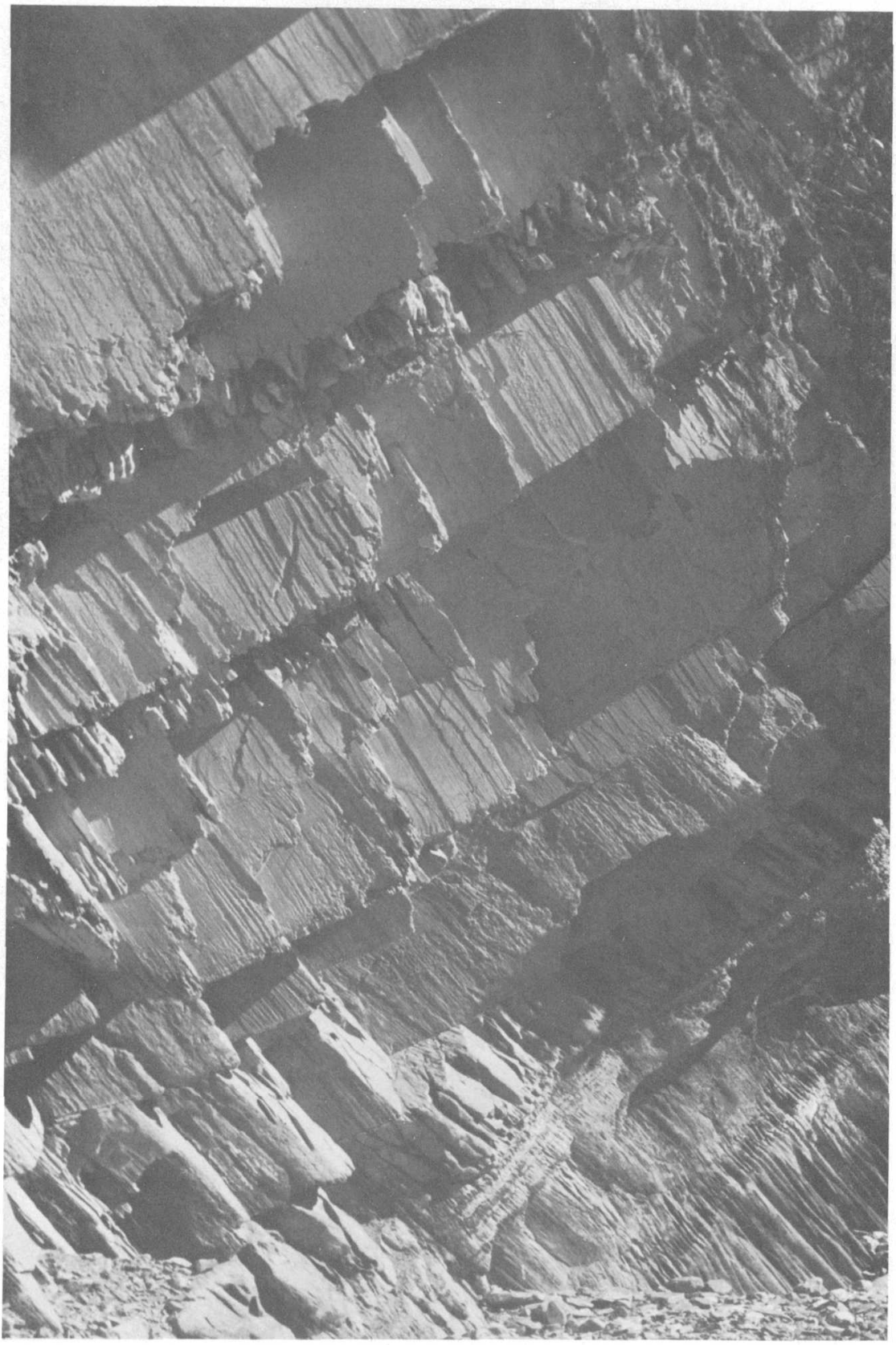

Figtre 29.-Fracture cleavage dipping steeply toward the right and cutting bedding in the Mexcala formation, ${ }^{\circ}$ which dips toward the left. Arroyo de Milpilla, about 9 $\mathrm{km}$ northeast of Peñamiller. Average spacing of the cleavage is about $1 \mathrm{~cm}$. 
surface of a gently dipping, thick sandstone or graywacke bed of the Las Trancas formation in Mina Grande, about $7 \mathrm{~km}$ north of Pinal de Amoles, resemble ripple marks. Thin lenses of chert in thickbedded El Doctor limestone $1 \mathrm{~km}$ southwest of Pinal de Amoles are crinkled, and both the chert and the encompassing limestone are cut by fractures. which are in axial-plane position with respect to the crinkles. The crinkles and their accompanying fractures are spaced about $15 \mathrm{~cm}$ apart; a similar relation has been observed and illustrated from the Zimapán mining district (Simons and Mapes, 1956, fig. 11).

The same fracture cleavage that is roughly parallel to the axial plane of one fold may cut the axial plane of a smaller adjacent fold at a high angle.

At a given locality the strike of fracture cleavage is commonly parallel, or nearly so, to the strike of the bedding, regardless of any local divergence in dip. However, wide divergence in the strikes may be noted locally at or near the noses of plunging anticlines. Conspicuous fracture cleavage in the Mexcala formation strikes $\mathrm{N}$. $50^{\circ} \mathrm{W}$. and dips $70^{\circ} \mathrm{SW}$. The cleavage cuts mudstone beds whose attitude is N. $20^{\circ}$ E. and $38^{\circ} \mathrm{W}$. at the mouth of Arroyo de Jasso $12 \mathrm{~km}$ northeast of Peñamiller. The observations of strike and dip at that place were made on the southwest side of the nose of a small northwest-plunging anticline.

The relation of fracture cleavage to the folds, as described above, indicates that the two types of structure were produced by the same compressive forces. The surfaces of breaking were not determined by a parallel arrangement of mineral particles; fracturing took place independently of any such arrangement.

A rare occurrence of "fracture cleavage along which there has been measurable differential movement" (Billings, 1942, p. 232) is in the Las Trancas formation along Arroyo de Xothé $3 \mathrm{~km}$ south of Higuerillas. A limestone bed between phyllite beds at that place has been fractured approximately normal to the bedding, and differential movement of as much as $1.3 \mathrm{~cm}$ has taken place along the fractures.

\section{THRUST FAULTS}

Overthrusts expose beds in the Las Trancas formation in small outcrops at a few places in the Bernal-Jalpan area. The best exposures are in the canyon of the Río Extórax between Peña Blanca and Adjuntas de Higuera, where variations from flat overthrusts to a reverse fault dipping $35^{\circ} \mathrm{SW}$. occur, but the observed displacements are not more than 1-2 $\mathrm{m}$. Similar small shear phenomena are seen northwest of Pinal de Amoles and about $8 \mathrm{~km}$ northeast of Peñamiller-the latter in beds of the Mexcala formation. At places 
where there is little displacement along fault planes, minor folds with sheared limbs show evidence of the same forces as those that produced larger scale thrusting (fig. 30). Overthrusting of beds, like most overturning of folds, is toward the east or northeast in the Bernal-Jalpan area.

Structural discordance between the Las Trancas formation and overlying rocks suggests that the great cliff of Cerro de la Media Luna may be the east edge of an overthrust block. The cliff is in El Doctor limestone, which in general flatly overlies relatively crumpled beds of the Las Trancas formation (fig. 31).

Where the contact between the Las Trancas and El Doctor units is well exposed, however, as along the Río Extórax between Peña Blanca and Adjuntas de Higuera, tight folding of the contact is seen at some places; moreover, the crumpling of Las Trancas beds extends for hundreds of meters below the contact. All the deformation of that incompetent rock unit, therefore, can hardly be attributed to drag near a thrust plane. There may have been no largescale overthrusting locally, and at least part of the structural discordancy noted above may be due only to differences in competency between the thin-bedded Las Trancas formation and the El Doctor limestone, which is locally thick-bedded. During folding, thin beds commonly become more crumpled than thick beds.

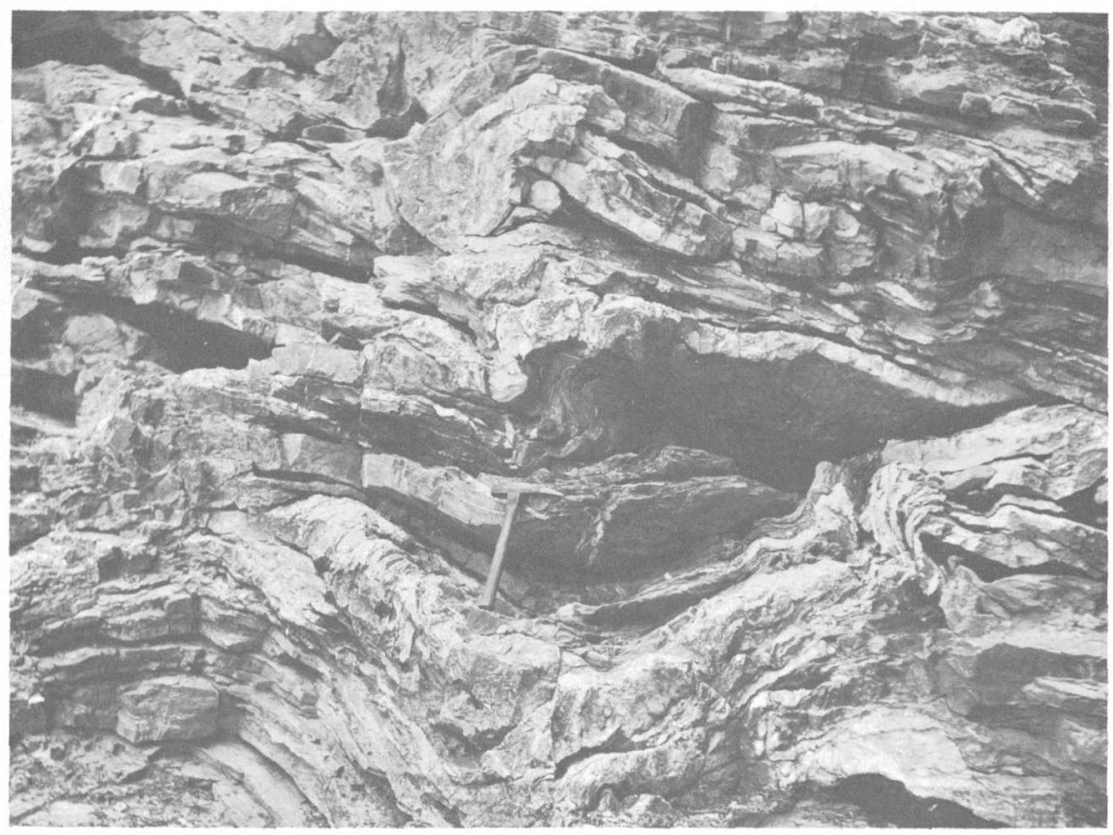

Figure 30.- Small folds with sheared limbs in the Las Trancas formation between Peña Blanca and Bucareli, as seen from the north. An effect like that of incipient thrusting from right (west) to left (east) is noted. 


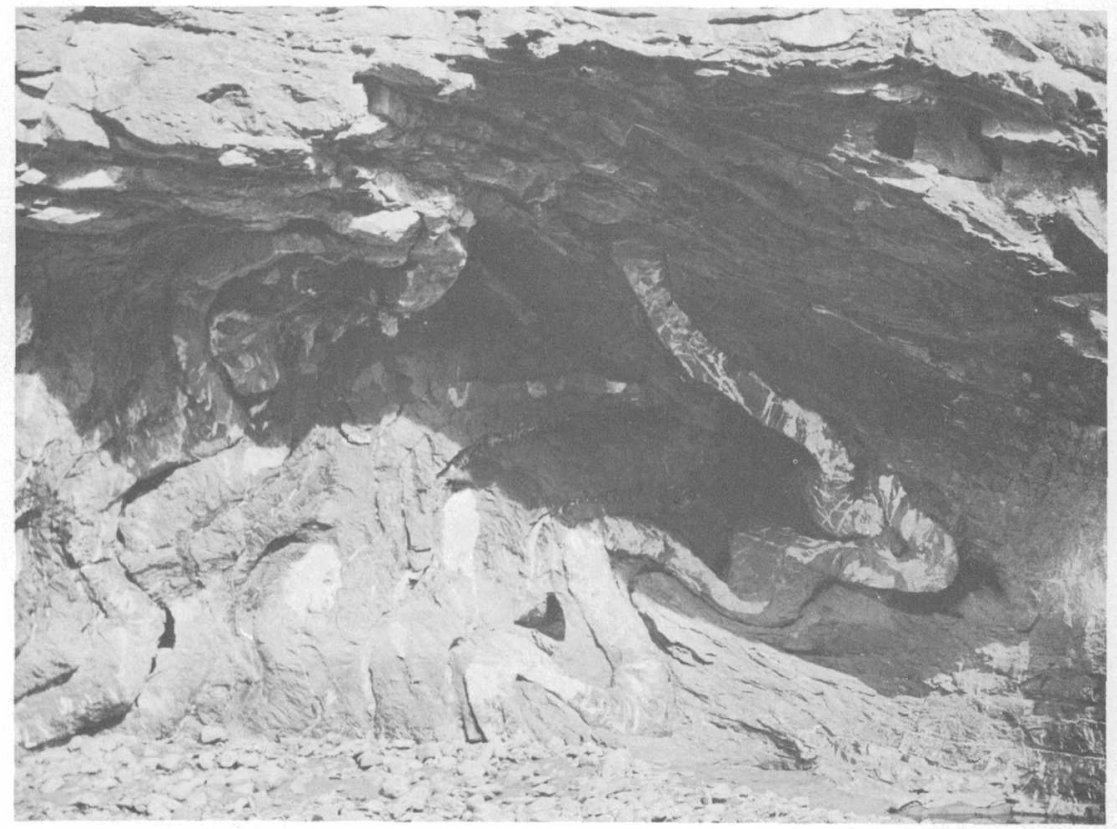

Figure 31.-Crumpled argillaceous limestone and calcareous phyllite beds of the Las Trancas formation under the great cliff of Cerro de la Media Luna.

\section{NORMAL FAULTS}

Rocks of both Mesozoic and Cenozoic ages have been cut by normal faults and are tilted along fault planes. Only observed major faults are shown on the map. In general, fault planes of the region dip steeply and strike parallel to the trend of fold axes, although a few faults (and dikes) strike northeastward. Movement of the hanging wall has been toward the direction of dip; there has been little strike-slip displacement.

The largest observed fault in the area has an average strike of about $\mathrm{N} .70^{\circ} \mathrm{W}$. and may be traced for at least $7 \mathrm{~km}$. It is located on the ridge between Arroyo del Saucillo and the Río Extórax 8-15 $\mathrm{km}$ northwest of Peñamiller. Where the fault plane is well exposed in a small arroyo, its dip is $45^{\circ} \mathrm{SW}$. and mudstone beds of the Mexcala formation on its southwest side are in contact with sandstone or graywacke of the Las Trancas formation to the northeast. A narrow outcrop belt of El Doctor limestone is displaced about $2 \mathrm{~km}$ along the fault. The displacement appears to be due to dip-slip movement of the gently dipping limestone rather than to actual lateral movement. The amount of vertical movement is conjectural; it may be hundreds of meters.

The northwest-striking El Raizal fault, north and east of Soyatal, was mapped for about a kilometer by White in 1944. Near Soyatal 
the fault dips $70^{\circ} \mathrm{SW}$. and the displacement may be $150 \mathrm{~m}$ or more, with the southwest side down (White, 1948, p. 50 and pl. 9). The fault was extended on plate 2 both northwestward and southeastward to a mapped length of about $5 \mathrm{~km}$. A dike follows the fault for nearly a kilometer east of Soyatal, and to the southeast of that place the fault forms the contact between the Las Trancas and Soyatal formations, the $\mathrm{El}$ Doctor limestone being absent.

Along Arroyo del Pilón $5 \mathrm{~km}$ east-northeast of Peñamiller, beds of the Mexcala formation are dropped on the southwest side of a fault that strikes N. $20^{\circ} \mathrm{W}$., dips $60^{\circ} \mathrm{SW}$., and has a gouge zone about $1 \mathrm{~m}$ wide. The outcrop belt of a sill $4-5 \mathrm{~km}$ up the arroyo from that place has been shifted $13 \mathrm{~m}$ laterally by another northweststriking fault. Along the Río Extórax about $3 \mathrm{~km}$ east of Peña Blanca and along Arroyo de Higuera about $3.5 \mathrm{~km}$ southeast of that place, several small faults (not shown on the map) strike north to northwest, are steeply dipping, and have their west sides dropped with respect to their east sides.

Northeast-striking faults in the Soyatal district, small and uncommon as compared with northwest-striking faults, have been briefly described (White, 1948, p. 50). A steep north-northeast-striking fault about $8 \mathrm{~km}$ north of Tolimán, drops a contact between El Doctor limestone and the Las Trancas formation about $75 \mathrm{~m}$ on the southeast side. A fault at the southeast edge of the large intrusive body near Río Blanco strikes $\mathrm{N}$. $55^{\circ} \mathrm{E}$. and dips $70^{\circ} \mathrm{SE}$.

Faults surround the rhyolite intrusive body near Bernal on all sides except the east. They are steeply dipping, and fault blocks lying outward from the stock are dropped downward as if a vertical doming force produced rupture and displacement. Magnitudes of the displacements are unknown, but they are sufficient to have caused shifting of surface contacts of the El Doctor limestone with older and younger rocks for hundreds of meters.

A short distance east of San Pedro Escanela, minor bedding-plane faults have dragged fracture cleavage in the hanging walls and caused the cleavage to be tilted almost at right angles to its original position. For tens of meters across the strike of vertical beds of argillaceous limestone at that place, each bedding plane is also a fault plane (fig. 32).

\section{JOINTS}

Jointing in rocks of the Bernal-Jalpan area was not extensively studied by the writer. In general, the thick-bedded rocks are cut by vertical or very steeply dipping joints whose strikes seem to be variously oriented. Flat-lying, gently dipping thick-bedded limestone of the El Doctor unit is commonly well jointed, and pronounced solution weathering occurs along the joints. Columnar jointing of basalt on a butte $1 \mathrm{~km}$ east of Peñamiller is exceptionally conspicuous. 


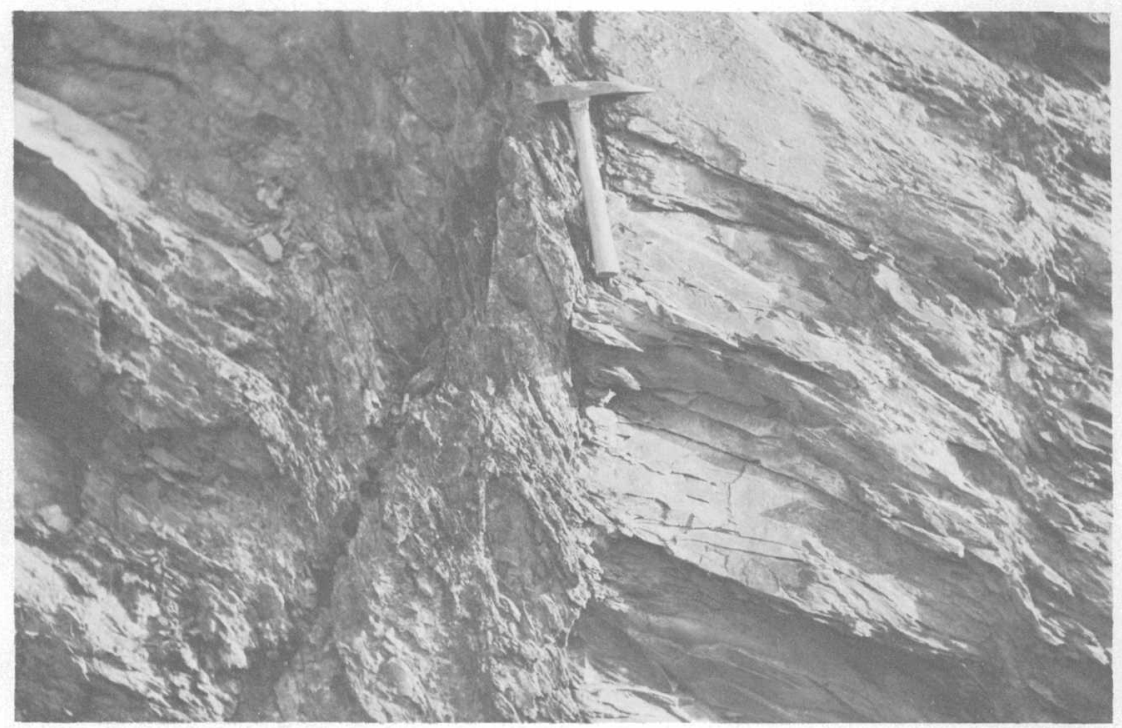

Figure 32.-Bedding (vertical) and fracture cleavage (dipping from left to right) in the Las Trancas formation, near San Pedro Escanela. Faulting along bedding planes has displaced and sharply dragged the fractures.

\section{GEOMORPHOLOGY}

\section{KARST FEATURES}

Because much of the present relief of the Bernal-Jalpan area has been formed in the El Doctor limestone, it is not strange that solution weathering has produced varied features of the karst erosion cycle, such as lapies, sínkholes (dolinen), caves, and underground channels. Areas of karst topography are everywhere being encroached upon by erosion incidental to surface runoff and masswasting; hence, locally, the karst surface has been destroyed. Elsewhere the karst cycle is at the stage of late maturity or old age.

\section{LAPIES}

Thick-bedded, nearly flat-lying El Doctor limestone locally shows an "*** etched, pitted, grooved, fluted and otherwise rugged surface to which the name lapies is most commonly applied" (Thornbury, 1954). Localities notable for lapies erosion are $5 \mathrm{~km}$ southeast of Pinal de Amoles between Puerto de Tejocotes and La Cantera, $7 \mathrm{~km}$ southeast of Jalpan at Tancama, and on the crest of a plunging anticline about $4 \mathrm{~km}$ west of Jalpan.

\section{SINKHOLES}

Most of the sinkholes, or dolinen, of the area occur northwest of Pinal de Amoles; one, about $400 \mathrm{~m}$ long and several tens of meters deep, lies at the very edge of town. Llano de San Francisco, the 
largest of these sinkholes, is about $700 \mathrm{~m}$ long and $50 \mathrm{~m}$ deep and is $6 \mathrm{~km}$ northwest of Pinal de Amoles, on the divide between Arroyo Hondo and Arroyo del Rodesno. Smaller sinkholes, each a hundred meters or so in diameter, occur on the divide between Arroyo Hondo and Río Blanco at Puerto del Tanque and to the north of Puerto del León, at distances of 10-13 km northwest of Pinal de Amoles. Other sinkholes lie at the head of Arroyo de la Barranca, $4 \mathrm{~km}$ southwest of Pinal de Amoles, and on the divide north of Mazacintla, $14 \mathrm{~km}$ east-southeast of Jalpan.

The sinkholes occur in two types of localities: in upland interfluval areas, and at the heads of arroyos, both areas of imminent integration of a surface drainage system. Sinkholes were much more numerous and widely distributed in the past than they are now; their number has been reduced and their distribution limited by headward erosion of surface streams.

The gravel deposit east of Tancama (p. 48) is probably made up of material that was washed into a large sinkhole or uvala, $7 \mathrm{~km}$ long and $1-4 \mathrm{~km}$ wide, that formed in limestone of the Jacala Bank. Integration of drainage at the surface with that of the Río Jalpan preceded dissection of the gravel.

\section{CA VES}

Caves are abundant in the El Doctor limestone near Pinal de Amoles, near Río Blanco, and at other places, but they were not explored by the writer and are not shown on the map of this report. One of the caves is in the core of a chevron anticline some tens of meters wide on the west side of Arroyo de la Barranca, about 4 $\mathrm{km}$ north of Pinal de Amoles. Several small cave openings are in the base of a calcarenite cliff $25 \mathrm{~m}$ high on the northeast side of Arroyo del Tránsito $4 \mathrm{~km}$ east-northeast of Río Blanco.

\section{UNDERGROUND STREAM CHANNELS}

Between Aguacatlán and Jalpan the Río Jalpan flows through a natural tunnel $1.5 \mathrm{~km}$ long and emerges at a place called Puente de Dios. For the last $250 \mathrm{~m}$ of its length the tunnel is $9-10 \mathrm{~m}$ wide and $6 \mathrm{~m}$ high (Reyes, 1880b). The tunnel was formed by subterranean stream piracy, which diverted surface waters from about 1,050 $\mathrm{m}$ above sea level on the west side of the limestone anticlinal ridge of Cerro del Fraile to about $900 \mathrm{~m}$ above sea level on the east side. A classical example of this sort of feature is the Natural Tunnel of Virginia (Woodward, 1936). Another natural tunnel is at Infiernillo, $9.5 \mathrm{~km}$ north of Pinal de Amoles, where Arroyo Hondo, locally following a subsequent course at the surface, abruptly cuts across the strike of limestone beds and follows an underground course for a short distance. 
During the dry season the Arroyo de Higuera carries a much larger volume of water at the surface than its parent stream, the Río Extórax, and yet practically all its permanent flow is derived from two enormous springs in the travertine-mantled south slope of the arroyo, one $500 \mathrm{~m}$ upstream from Adjuntas de Higuera and the other $200 \mathrm{~m}$ farther upstream. These springs are supplied by subterranean drainage of a well-watered upland that formed on the Cerro Ladrón limestone bank to the south. The Arroyo de Higuera is eroded below the contact of the limestone with the underlying, relatively impermeable phyllite of the Las Trancas formation. The springs occur at this contact.

The Río Blanco is converted from an intermittent stream to a strong perennial one near the town of Río Blanco by the emergence of two underground streams in tributary gullies southwest and east of the town. Río Blanco is in an arid region at $1,800 \mathrm{~m}$ above sea level, but a well-watered upland rises to more than $3,000 \mathrm{~m}$ only a few kilometers to the east and south of that place. The sinkholes suggest that drainage of the highland is largely subterranean, and it seems likely that part of the underground drainage emerges in the Río Blanco springs.

\section{OLD EROSION SURFACES}

The Sierra Gorda summit region is the oldest exposed erosion surface in the area. Within the Pinguiical-Pinal de Amoles area, this rolling surface of deeply weathered bedrock is eroded almost entirely in El Doctor limestone; far to the west, outside the area covered by the present report, it is eroded in volcanic rocks of middle Tertiary age. The main upland surface, which has reached the stage of late maturity in the erosion cycle, has been indented by mountain valleys at some places and is everywhere being reduced by the headward retreat of youthful, cliff-lined gullies. The Arroyo de la Barranca and the Río Blanco exhibit valley-in-valley transverse profiles north of Pinal de Amoles and northwest of Río Blanco, respectively, where mountain-valley and canyon stages of erosion of the old upland surface are well defined.

The younger Vizarrón surface lies west of the Pingüical-Cerro Ladrón highland at about 1,900-2,150 $\mathrm{m}$ above sea level (B. W. Wilson and others, written communication). To the south where it is partly covered by gravel, this erosion surface is largely formed on the Soyatal and Mexcala formations; to the north it has formed on volcanic rocks of middle Tertiary age. Although the surface is deeply dissected everywhere, extensive remnants remain near Vizarrón, outside the area about $11 \mathrm{~km}$ southeast of Higuerillas.

A 250-meter escarpment at Divisadero, between Higuerillas and the 
village of Vizarrón, forms the boundary between the Vizarrón surface and the next lower one (fig. 33). North of the escarpment the surface is preserved on the flat lava-covered tops of Cerro de la Tembladera and on a ridge near Las Mesas that extends southward from higher volcanic terrain that rises to the north. The surface is also fairly well preserved in the Mexcala formation along the gently rolling watershed divide between Arroyo de Milpilla and the Río Blanco, in the vicinity of Puerto Blanco.

An extensive surface has been eroded to late youth in the Mexcala formation in the lowland near Peña Blanca; it extends about $15 \mathrm{~km}$ to the north and south of that place and about $6 \mathrm{~km}$ to the west at altitudes of about 1,450-1,700 m above sea level. It is here proposed to name this feature the Peña Blanca surface (fig. 34). The surface has been dissected to an average depth of about $75 \mathrm{~m}$ by the Río Extórax and its chief tributaries, but it is in general better preserved than the higher Vizarrón surface.

The old erosion surfaces described above are probably all of Quaternary age, and the Peña Blanca surface is certainly not older than late Pleistocene. However, the Peña Blanca surface is probably not of Recent age, for not only has there been considerable later dissection, but during the dissection period the base level must have been temporarily raised. The main arroyos that were cut below the old surface as much as $75 \mathrm{~m}$ were filled to a depth of about $10 \mathrm{~m}$ by gravel and other detrital material; then, when the base level was

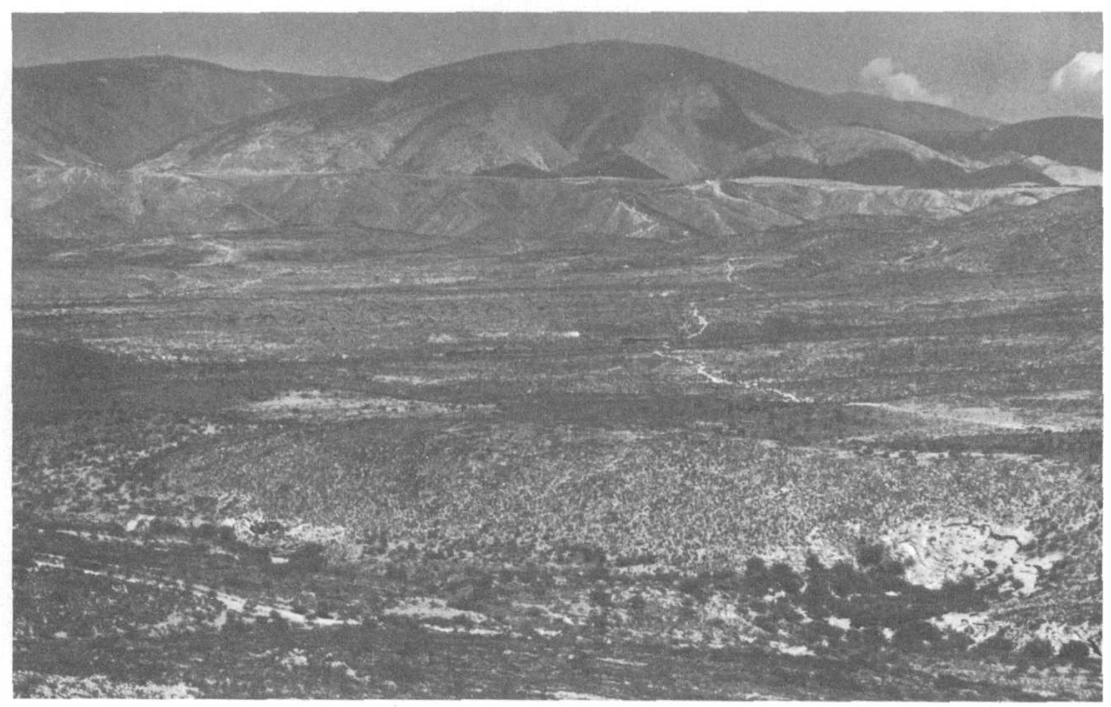

Figure 33.-The Divisadero escarpment at the edge of the Vizarron erosion surface, or terrace. The distant mountain is Cerro Ladrón, and the dissected foreground is the Peña Blanca surface. 


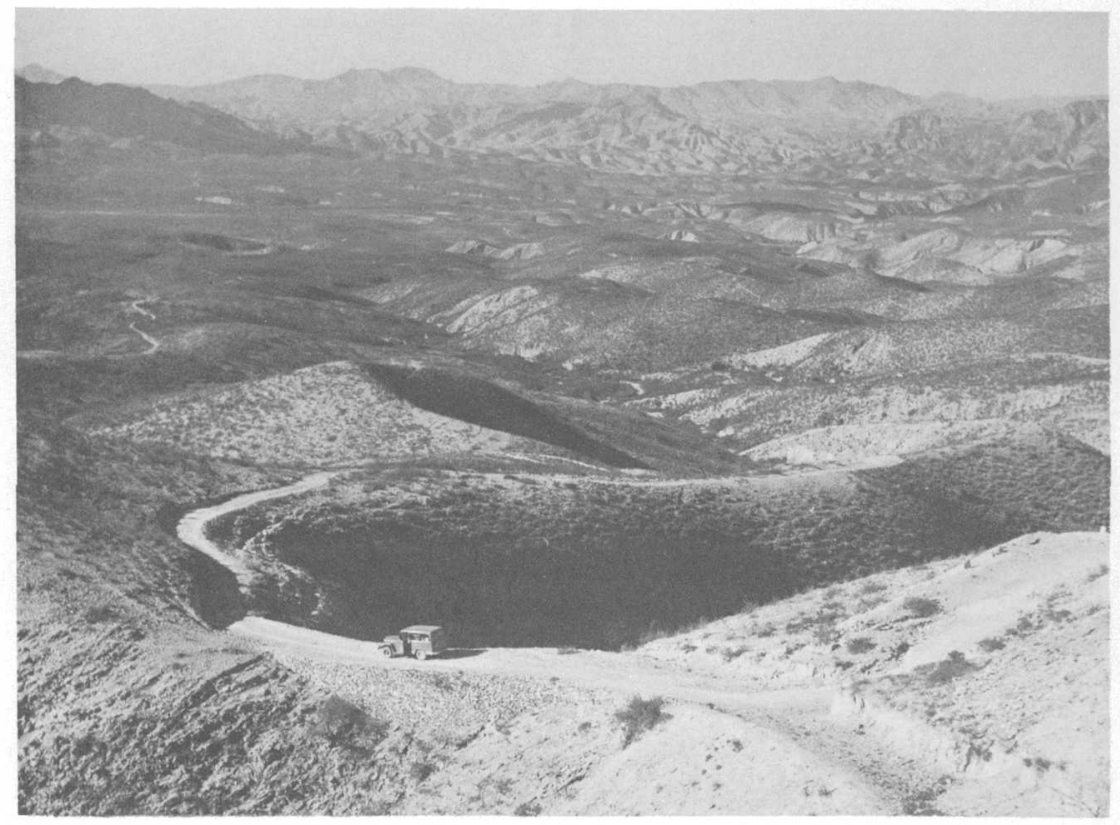

Figure 34.-The Peña Blanca erosion surface, as seen looking north from part way down the escarpment of the Vizarrón surface near Divisadero.

relowered, the erosion of the gravel left terrace remnants on the sides of the arroyos. The time required for this erosion, deposition, and renewed erosion is probably greater than that encompassed by the Recent epoch.

\section{DRAINAGE DEVELOPMENT}

Salient features of the Bernal-Jalpan drainage are a series of gorges along the Río Extórax which cuts downward across folds in the Mesozoic rocks to altitudes of 700-1,200 m above sea level, and the lofty uplands that rise both north and south of these gorges in the central part of the area to altitudes of over $3,000 \mathrm{~m}$.

Buttes and ridges of andesite and rhyolite flow rock west of the uplands, where the altitude does not exceed $2,300 \mathrm{~m}$, indicate that all that part once had a cover of rocks of Cenozoic age, as do the extreme western and southwestern parts at the present time. The central and eastern parts are without erosional remnants of flows, except for two small patches of relatively late basalt far down the north side of one of the gorges of the Río Extórax. The western region is one of little limestone, whereas to the east the El Doctor limestone is a thick unit on which an extensive erosional surface has formed. The limestone has karst features, but much of its drainage is surface. 
The relatively great height of the central area is probably due in part to the fact that drainage has been subterranean and that little surface erosion has taken place. It may be deduced that the area was too high to be covered by the great flood of andesite and rhyolite farther west,

Superposition from the volcanic cover may explain the present course of the Río Extórax in the western part of the Bernal-Jalpan area, but a different process must have produced the deep gorges in the central and eastern parts. This process may have been the subterranean draining of the limestone, followed by collapse of tunnels and integration of a through-going drainage system at the surface.

Subterranean stream piracy was suggested as the chief cause of drainage integration in the Río Jalpan valley at Puente de Dios ( $p$. 71 ); it may have been equally important in integrating the drainage of ancient subsequent valleys farther up the Río Extórax between $\mathrm{Bu}$ careli and Santa Clara. Lying as they did on the eastern limb of the Pinguiical anticline, each of these ancient valleys was higher than the next one to the east; this position allowed "**** water from the higher stream to seek an underground route," as Woodward (1936) said of the Natural Tunnel area of Virginia.

Capture of drainage at the southwest corner of the area is progressing at a geologically rapid rate. Bernal, 2,028 $\mathrm{m}$ above sea level, is at present on the divide between the Río Extórax to the north and the Río San Juan to the south. Between Bernal and Tequisquiapan, $24 \mathrm{~km}$ to the south, the drop is only $143 \mathrm{~m}$, whereas that between Bernal and San Pablo, $12 \mathrm{~km}$ to the north, is no less than $493 \mathrm{~m}$. The mean drop to the north is more than $37 \mathrm{~m}$ per $\mathrm{km}$, as compared with only $6 \mathrm{~m}$ per $\mathrm{km}$ to the south. Because of its steeper gradient, the Río Extórax is constantly extending its drainage area southward at the expense of the Río San Juan.

\section{EROSION FORMS}

Unusual erosional forms have evolved in the Bernal-Jalpan area. These forms, which include bernales, pepino hills, potholes, casas de piedra (stone houses), and a natural bridge, are of little topographic importance, but they are geologically interesting. Except for the potholes, these products of weathering and erosion are not common in most parts of the world.

Weathering and erosion along vertical joints in coarse thickbedded flat-lying volcanic breccia has produced rows of closely spaced pinnacles 10-20 m high on Cerro de los Bernales, $7 \mathrm{~km}$ northnorthwest of Pinal de Amoles. Inasmuch as the breccia fragments are more resistant to weathering and erosion than the matrix, they tend to project outward from weathered surfaces, and some of them a meter or even more in diameter rest as "balanced rocks" on pedes- 
tals. Cerro de los Bernales (Hill of the Pinnacles) should not be confused with Peña de Bernal (Pinnacle Rock) the rhyolite neck described on page 54, or with other bernales (pinnacles, usually of volcanic rock) which are common in certain parts of Mexico.

The limestone upland northwest of Pinal de Amoles is in an advanced stage of solutional destruction and is partially dissected by the encroachment of surface streams. Rounded residual knolls 50$150 \mathrm{~m}$ high rise above benchlike remnants of the old surface. These picturesque eminences, which have convex upslope profiles rather than the concave upslope profiles usually characteristic of maturely eroded hills, are like the pepino hills of Puerto Rico. The hills rise out of areas of sinkholes near Puerto del Tanque and Puerto del León, about 9-13 km from Pinal de Amoles.

Large potholes occur in limestone along the Río Extórax and some of its tributaries between Peña Blanca and Las Medias. No potholes were seen in the bed of the main river, which is covered with gravel and boulders, but many as much as $3 \mathrm{~m}$ in diameter are visible along the walls of the gorge several meters above the level of the river bed. Potholes are particularly numerous about $4.5 \mathrm{~km}$ east of Peña Blanca where the lower end of Arroyo del Aguacate descends precipitously into the Río Extórax. These hollows in solid rock in and along the watercourses attest to the abrading power of the streams even though they are intermittent or at best have very small perennial flow.

Blocks of thick-bedded El Doctor limestone (casas de piedra) as much as $10-15 \mathrm{~m}$ in diameter have fallen from the cliffs above into the watercourse and are too large to be moved even by floods; they occur singly, in pairs, and in groups along the Río Extórax and its largest branches. They are found at several localities, one of which is on the Río Extórax about $4 \mathrm{~km}$ east of Peña Blanca, and another on the Río Tolimán about $6.5 \mathrm{~km}$ west-southwest of Peñamiller. The "stone houses" occur where there are large roomlike openings between-pairs and groups of enormous limestone boulders. At places the openings appear to have been enlarged through abrasion by detritus-laden flood waters.

A natural bridge of El Doctor limestone occurs on a spur ridge that rises between the limbs of a U-shaped bend of the Río Extórax, about $7 \mathrm{~km}$ east of Bucareli. This feature, known locally as La Ventana (The Window), is about $12 \mathrm{~m}$ high and has a span of about $10 \mathrm{~m}$. It has been formed in chevron-folded limestone by solution weathering.

\section{GEOLOGIC HISTORY}

The oldest event of which there is visible record in the BernalJalpan area is the deposition of shale and sandstone in a sea during or before Early Jurassic time. Regional metamorphism, which 
ceased before or during Middle Jurassic time, converted these sedimentary deposits to mica schist and quartzite. Further marine deposition of clastic materials followed during the latter part of Middle Jurassic or the early part of Late Jurassic time. The existing sedimentary and metamorphic rocks were eroded where there was local emergence. General submergence followed, and graywacke, arkose, chert, calcareous shale, and argillaceous limestone were deposited in the sea during the Callovian, Oxfordian, Kimmeridgian, and Portlandian stages of Late Jurassic time.

Owing to a withdrawal of the sea and to differential uplift, the Bernal-Jalpan area was a landmass during much of Early Cretaceous time. As a result, the epoch was one of nondeposition in the eastern part of the area and of erosion in the western part so deep that locally, as at Bernal, the Las Trancas clastic beds and impure limestone were completely removed.

A general submergence began in the eastern part of the area probably in middle Albian time and progressed westward during late Albian time. The limestone Jacala Bank was built in the eastern part of the area, parallel to the shore of an ancient sea but many tens of kilometers seaward (eastward), and at the same time the Cerro Ladrón Bank was built south of the middle part of the area. The submergence continued probably into early Cenomanian time and was followed by uplift and emergence that lasted until late Turonian. Renewed submergence in late Turonian time continued into Maestrichtian. Toward the close of the Cretaceous period the entire region was uplifted and has continued to be emergent.

The Cenozoic history of the region began with the folding of all rocks that had been deposited in Cretaceous and earlier times. Folding continued until late Eocene time and was followed by blockfaulting, erosion, extensive volcanism, and local terrestrial deposition. The Cenozoic record of the area is neither as clear nor as complete as it is for the Estado de Hidalgo (Segerstrom, 1956). The deepening of the Río Extórax and Río Jalpan valleys has been the latest observable geologic change and this is still going on today.

\section{MINERAL DEPOSITS}

\section{METALS}

\section{MINING ACTIVITY AND PRODUCTION}

The local mining industry dates back to early colonial times. Slag piles and the ruins of small smelters built for treating lead ore are located along several creeks and gulches north and east of Pinal de Amoles. The Spaniards also mined considerable gold and silver at San Martín Ajuchitlán and at Río Blanco. Early mining methods at Río Blanco consisted of breaking the rock for removal by first 
heating it with wood fires and then dashing water against the heated surface. Antimony was first mined at Soyatal in 1905. Data on the history and production of local mines have been so poorly kept that it is impossible to present a continuous record of the exploitation of mineral deposits of the Bernal-Jalpan area.

Mining activity in the area was described in 1794 by D. Fausto Elhúyar, Director General of Mining for the Province of New Spain :

"In the San José de Pinal district [Pinal de Amoles], there are at present 13 mines, but only four of them, Santo Domingo, Nuestra Señora de Guadalupe, Animas, and Santa Clara, *** are active. Among several mines that lie within the Real [royal district] de Escanela [San Pedro Escanela], only two, San Ildefonso and San Antonio de los Muertos, are active and in [scarce] production. ${ }^{*} * *$ The activity of the Real de Escanelilla is confined to treating and smelting metalliferous ores. San Antonio and Santísima Trinidad are producing low-grade ores in the Real de Ríoblanco. ${ }^{*} * *$ The producing mine of the Juchitlán [Bernal] district is the Santa Gertrudis, which is the property of the Count of Regla." (Velasco, 1891, p. 132-134.)

Mines have been operated during recent years in only three districts: the Soyatal, which during the war-boom years of 1942 and 1943 was producing about 1,800 metric tons of metallic antimony per year (White, 1948); the Pinal de Amoles, which in 1952 was producing metallic lead at a rate of about 100 tons per year (extracted chiefly from old slag piles); and the Río Blanco, which until 1945 had several active arrastres (drag-stone mills) where small amounts of gold and silver were extracted. Production of silver and gold has been almost negligible in recent decades, but in 1914 about 40,000 tons of ore with an average value of $\$ 5.00$ per ton was produced at San Martín Ajuchitlán (unpublished mining company report by $\mathrm{C}$. Crowell, 1942). According to the Dirección de Minas y Petróleo of the Mexican Government (unpublished report, 1956), the production of metals for Querétaro for 1954 was gold, $1 \mathrm{~kg}$; silver, 1,611 $\mathrm{kg}$; lead, 210,475 kg; copper, 1,394 kg. These figures include production from El Doctor mining district, which is outside the BernalJalpan area.

\section{DISTRIBUTION}

Metalliferous mineral deposits are of wide geographic distribution in the Bernal-Jalpan area. The chief mining districts are those of Pinal de Amoles, Tolimán, Soyatal, Bernal, and Río Blanco. The chief metals that have been extracted from these deposits are lead, zinc, antimony, silver, and gold. Small amounts of copper, manganese, mercury, and arsenic have also been extracted. Lead, zinc, and silver have been the chief products of the mines of the Pinal de 
Amoles district (Queso-Animas, Poder de Dios, Mina Grande, Tiro México, Santiago, San Vicente) and that of Tolimán (Plomosas, Ixphé, Nopalillo, Santa Teresita), but antimony has been practically the only metal obtained from the Soyatal district (Santa María de Miera, Santo Niño, Santo Domingo). In the districts of Bernal (San Martín Ajuchitlán, La Chicaroma) and Río Blanco (Rosario, Guadalupe, Cueva del Oro), the principal values have been in gold and silver. Mines are located outside these districts at the following places: (a) Cerro del Soyatal, $13 \mathrm{~km}$ east-southeast of Jalpan (silver and gold(?), (b) Arroyo del Limón, $17 \mathrm{~km}$ southeast of Pinal de Amoles (lead and zinc), (c) Pitahayo, $2 \mathrm{~km}$ west-southwest of Peñamiller (silver(?)), and (d) Cerro Prieto, $1.5 \mathrm{~km}$ northwest of Palmas (lead and manganese).

A belt of metalliferous mineral deposits extends from Teziutlán, northwest to Xichú, (Guanajuato), a distance of $320 \mathrm{~km}$. The Bernal-Jalpan area is near the northwestern end of the belt; Río Blanco, Querétaro, is about $40 \mathrm{~km}$ southeast of Xichú. The zone within which the deposits occur is broad and its boundaries are not sharp, but its proximity to the area of this report is worthy of consideration, for no known metalliferous mineral deposits occur for many tens of kilometers either to the northeast of Jalpan or to the southwest of San Martín Ajuchitlán.

\section{ORE MINERALOGY AND HOST ROCK}

In the Pinal de Amoles district the ore minerals are mostly cerussite, anglesite, silver chloride, and free gold, occurring with sphalerite, stibnite, pyrite, and arsenophyrite (Queso-Animas, Poder de Dios, Tiro, México, Santiago), and galena occurring with sphalerite (Mina Grande). The difference between these two associations of minerals is probably due to differences in elevation: Mina Grande is in the deep Barranca Grande, where downward erosion may have been more rapid than the downward oxidation of lead sulfide (unpublished mining company report by W. J. Shedwick, Jr., 1952). Both oxidized lead minerals (Plomosas) and galena (Ixphé, Nopalillo) occur in the Tolimán district. In the Soyatal district, antimony oxides and stibnite, which occur in the ratio of 2 or 3 to 1 , are the minerals of greatest economic importance (White, 1948).

In the Bernal district (San Martín Ajuchitlán) the ores are silicified shale fragments containing free gold and silver, and in places iodides, bromides, and chlorides; however, sulfides (Lewis, 1920) appear to be completely absent, and it is not known if halides are present in the rest of the Bernal district (La Chicaroma). Oxidized silver minerals and free gold occur with small quantities of azurite and malachite in the Río Blanco district. 
The host rocks of the Pinal de Amoles district are of great variety, ranging from the El Doctor limestone (Queso-Animas) and argillaceous limestone or calcareous mudstone of the Las Trancas formation (Mina Grande) to contact rock between the El Doctor limestone and igneous bodies (Poder de Dios, Tiro México, Santiago, San Vicente). The host rocks of the Tolimán district are the El Doctor limestone (Plomosas) and graywacke of the Las Trancas formation (Ixphé and Nopalillo). The ore deposits of the Soyatal district occur at and near the top of the El Doctor limestone, just below its contact with the Soyatal formation.

The host rocks of the Bernal district are the thin-bedded El Doctor limestone, shale of the Mexcala formation (San Martín Ajuchitlán), and pre-Las Trancas phyllite (La Chicaroma). In the Río Blanco district the host rocks are diorite (Guadalupe) and contact rock between diorite and the El Doctor limestone (Cueva del Oro, Rosario). The deposit on Cerro del Soyatal east-southeast of Jalpan is in the bank facies of the El Doctor limestone, but most of the rest of the scattered deposits outside the mining districts (Arroyo del Limón, Pitahayo, and part of Cerro Prieto) are in the Las Trancas formation. A small deposit of hydrous manganese oxide on Cerro Prieto is in rhyolite.

\section{GEOLOGIC OCCURRENCE}

The ore bodies in the Pinal de Amoles district are at or near intrusive contacts (Tiro México, Santiago, San Vicente), in chimneys (Queso-Animas), in veins (Poder de Dios), and in mantos or beds (Queso-Animas). The Pinal de Amoles district has furnished an example "*** showing the progress of a silver-lead mineralizer from source to surface and how erosion may affect its manifestations" (Fletcher; 1929). In the Tolimán district both mantos or beds (Plomosas) and veins (Ixphé, Nopalillo) carry the ore, and there are no known intrusive bodies nearby. The ore of the Soyatal district occurs in limestone beds near steep fractures, under shale, and in the upper parts of anticlinal structures; the only nearby igneous bodies are porphyry dikes and extrusive andesite (White, 1948).

In the Bernal district, the San Martín Ajuchitlán ore body is a contact deposit in sedimentary rock. The ore occurs in lenses $25-30$ $\mathrm{m}$ from intrusive rhyolite that is apparently related to the rhyolite plug of the Peña de Bernal (Lewis, 1920). The La Chicaroma deposit is in the zone of a conspicuous fault in sedimentary rock not far from the Peña de Bernal igneous body. In the Río Blanco district, the ore has been found along intrusive contacts (Cueva del Oro, Rosario) and along a vein well inside the intrusive body (Guadalupe). Placer gold occurs in gravels of the Río Blanco several kilometers downstream from the town of Río Blanco (Reyes, 1880a). The deposit on Cerro del Soyatal is along a vein in sedimentary 
rock, and there are no known igneous bodies for many kilometers in any direction. The mine at Arroyo del Limón is at and near the contact of a porphyry dike with silicified beds. The deposit at Pitahayo is in a fault zone, and no intrusive rock is visible nearby. A manto on Cerro Prieto seems to have yielded the lead ore that has been taken from that place, and a vein in nearby rhyolite has yielded hydrous manganese oxide.

\section{NONMETALS}

Limestone and clay are the nonmetallic products of greatest volume in the area at the present time. Building stone has been quarried for local use in the past. Opals are mined a short distance outside the area.

The lime industry is centered about the towns of Bernal and San Pablo, near which oil-burning kilns for calcining calcium carbonate were built during the period $1950-53$ and from which the markets of the thickly populated Bajío region to the west are easily accessible. Both caliche and the El Doctor limestone are used for raw material. Near Cerro del Pajarito $3 \mathrm{~km}$ east of San Pablo the caliche layer, $30 \mathrm{~cm}$ thick, is quarried with picks and crowbars and is fed to the kiln. A quarry $1.5 \mathrm{~km}$ east of Bernal supplies limestone to a large kiln. The hills and gullies between Bernal and San Pablo are dotted with small kilns where mesquite and other desert woods have been burned to heat the caliche, vaporize its carbon dioxide content, and convert it to quicklime.

Kaolin and montmorillonite are mined in open pits west of Tolimán and Palmas. The clays are alteration products of the chemical decomposition of tuffs, chiefly rhyolitic. The La Presa kaolin mine, about $1 \mathrm{~km}$ west-northwest of Palmas, is an open cut in a bed of rhyolite tuff $8 \mathrm{~m}$ thick.

La Misión, a large church near Bucareli, was constructed of cut stone over a century ago. The stone was hauled from La Cantera, $7.5 \mathrm{~km}$ away, where it was quarried from a deposit of soft altered breccia containing fragments of limestone and igneous rock.

The State of Querétaro is famed for its production of gem opals. The opals occur in porphyritic rhyolite lava flows, outside the area described herein, on Cerro Grande and near Hacienda de la Esperanza, which are about $20 \mathrm{~km}$ west and southwest, respectively, of Bernal.

\section{REFERENCES}

Billings, M. P., 1942, Structural geology: New York, Prentice-Hall, 473 p.

Bodenlos, A. F., 1956, Notas sobre la geología de la Sierra Madre en la sección Zimapán-Tamazunchale: Internat, Geol. Cong., 20th, Mexico D.F., 1956, Excursions A-14 and C-6, p. 293-309.

Burckhardt, Carlos, 1930, Étude synthétique sur le Mésozoique méxicain: Soc. Paléont. Suisse Mém., v. 49-50, 280 p. 
Cloos, Ernst, 1946, Lineation: Geol. Soc. America Mem. 18, 122 p.

1947, Boudinage: Am. Geophys. Union Trans., v. 28, p. 626-632.

Fletcher, A. R., 1929, Mexico's lead-silver manto deposits and their origin: Eng. and Mining Jour., v. 127, p. 509-513.

Fries, Carl, Jr., 1956, Bosquejo geológico de la región entre México, D. F., y Acapulco, Guerrero: Internat. Geol. Cong. 20th, Mexico, D. F., 1956, Excursions, A-9 and C-12, p. 7-53.

Fries, Carl, Jr., Hibbard, C. W., and Dunkle, D. H., 1955, Early Cenozoic vertebrates in the red conglomerate at Guanajuato, Mexico: Smithsonian Inst. Misc. Coll., v. 123, no. 7, 25 p.

Imlay, R. W., 1942, Late Jurassic fossils from Cuba and their economic signifcance: Geol. Soc. America Bull., v. 53, p. 1417-1478.

1952, Correlation of the Jurassic formations of North America, exclusive of Canada: Geol. Soc. America Bull., v. 63, p. 953-992.

Lewis, S. J., 1920, The ore deposits of Mexico: San Francisco, Mining and Scientific Press, 47 p.

Quiroz-Martínez, R., 1932, Querétaro, sus elementos de riqueza: Irrigación en México, v. 4, p. 369-381.

Reyes, J. M., 1880a, Los minerales de la Sierra de Querétaro: Soc. Geografía $\mathbf{y}$ Estadistica Bol., v. 5, p. 352-367.

1880b, Breve reseña histórica de la emigración de los pueblos en el continente americano: Soc. Geografía y Estadística Bol., v. 5, p. 385-457.

Segerstrom, Kenneth, 1956, Estratigrafía y tectóníca del Cenozóico entre México, D. F., y Zimapán, Hidalgo: Internat. Geol. Cong., 20th, México, D. F., 1956, Excursions, A-3 and C-1, p. 11-22.

Simons, F. S., and Mapes V., Eduardo, 1956, Geology and ore deposits of the Zimapán mining district, State of Hidalgo, Mexico: U. S. Geol. Survey Prof. Paper 284, 128 p.

Thornbury, W. D., 1954, Principles of geomorphology: New York, John Wiley \& Sons, $618 \mathrm{p}$.

Velasco, A. L., 1891, Geografía y estadística del Estado Querétaro Arteaga: Geografía y estadística de la República Mexicana, v. 7, 140 p.

White, D. E., 1947, Diagenetic origin of chert lenses in limestone at Soyatal, State of Queretaro, Mexico: Am. Jour. Sci., v. 245, p. 49-55.

1948, Antimony deposits of the Soyatal district, State of Queretaro, Mexico: U. S. Geol. Survey Bull. 960-B, p. 35-88.

Wilson, B. W., Hernández M., J. P., and Meave T., Edgardo, 1955, Un arrecife Cretácico en la parte oriental del Estado de Querétaro: Soc. Geol. Mexicana Bol., v. 18, p. 1-10.

Woodward, H. P., 1936, Natural bridge and Natural Tunnel, Virginia: .Jour. Geology, v. 44, p. 604-616. 


\section{INDEX}

A

Accessibllity

Acknowledgments

Adjuntas de Higuera, thrust faults

Agriculture.

Andesite dikes...

Anglesite, ore mineral.

Antimony mining

Archeology

Arquitos, Pingüical anticline

Arroyo de Milpilla, fracture cleavage in Mexcala formation ................

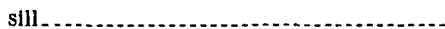

Arroyo del Trạnsito, travertine.

Arsenic mining.

Balanced rocks

Basalt.

Bernal, caliche. volcanic rocks

Bernal mining district, activity and production

geologic occurrence of ore bodies

Bernales

Boudinage.

Bucarell, boudinage and folds in El Doctor limestone near.

Building stone

\section{C}

Caliche, description and distribution ......... 50-51 source of lime.

Casas de pledra.

75,76

Caves.

Cenozolc geologic history

Cerro de la Cruz, volcan

Cerro de la Media Luna, possible overthrust block.

Cerro de la Tembladera, Vizarrón erosion surface.

volcanic rocks

Cerro de los Bernales, volcanic rocks

Cerro del Pajarito, volcanic rocks.

Cerro del Palo Alto, El Morro fanglomerate near.

Cerro del Picacho, volcanic rocks.

Cerro del Pilón, volcanic rocks.

Cerro del Sombrerete, volcanic rocks.

Cerro del Zacamecate, volcanic rocks

Cerro Ladrón Bank, description.

geologic history

Cerusite, ore mineral

Clastic deposits, fracture cleavage

late Cenozoic age

$75-76$

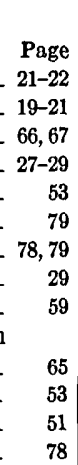

Climate

Contact-metamorphic rocks.

Cooperation..................................... 21

Copper mining............................... 78

Cretaceous geologic history .................... $\quad 77$

Cretaceous system, El Doctor limestone...... 34-40

Soyatal and Mexcala, undifferentiated.... 40-43

Crops grown in area....................... 28

Cueva del Oro mine, tactite ${ }_{2} \ldots . . . . . . . . . . . .56$

D
Dairy farming

Dikes . . .

Divisadero escarpment..................... 73

Dolinen. See Sinkholes.

Drainage................................... 24, 74-75

arly inhabitants . ......................... 29

El Buey, gravel terrace...................... 49

Chilar anticline

Doctor limestone, age............ 34, 35, 36, 37,39

boudinage............................... 62,63

description and distribution. .......... 25, 34-39

erosion forms................................ 76

exposed in Jalpan syncline................. 62

faults................................... $67,68,69$

folds............................. $57,58,59,60,62$

fracture cleavage........................... 66

host rock............................... $\quad 80$

in landslide................................ 48

intruded by stock . .

karst features............................ 70-72

old erosion surface........................ $\quad 72$

relation to contact-metamorphic rocks.... $\quad 56$

relation to El Morro fanglomerate........ 43

relation to Las Trancas formation. . 31, 34, 39, 40

relation to red soil........................ 51

relation to travertine. ..................... 51,52

relation to undifferentiated volcanic rocks. 44,46

source of lime....................... 81

E] Jagüey, caliche............................. 50

El Morro fanglomerate, age.................. 44 description and distributlon............... 43-44 relation to volcanic rocks, undifferentiated. 47

El Raizal fault description................... 68-69 rhyolite dike along...................... 54-55

Erosion forms............................. 75-76

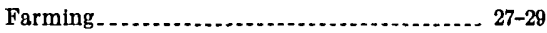

Faults .............. $66-69$

Fieldwork............................................ 19-21

Folds ..................................... 57-62,63 
Fossils, E1 Doctor limestone....... $34, \begin{array}{r}\text { Page } \\ 35,36,37,39\end{array}$

El Morro fanglomerate

Jacala Bank

Las Trancas formation. . . . . . . . . . . . . . 31-33

Soyatal and Mexcaia formations, undifferentiated............... $42-43$

Fracture cleavage............ 64-66

Fruits grown in area................ 28

\section{G}

Geography.

$21-29$

Geologic history

Geologic occurrence of metals. . . . . . . . . . . . 80-81

Geomorphology, drainage development...... 74-75 erosion forms. . . . . 75-76

karst features. . . . . . .

old erosion surfaces. . . . . . . . . . . . . . . . 72-74

Gold minlng.................... 77, 78, 79

Gravel................... $48-50$

$\mathrm{H}$

Higuerillas, fracture cleavage in Las Trancas

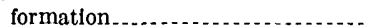

Las Trancas formation . ..................

Host rocks for ore.

I

\section{I}

Igneous rocks, Tertiary system.

Intrusive rocks, equigranular porphyritic.

Irrigation

\section{$J$}

Jacala Bank, description effect on folds

geologic history red soil.

Jalpan, caliche.

lapies erosion.

Jalpan syncline

Joints.

Jurassic geologic history

Jurassic system, Las Trancas formation....... 30-34

Jurassic system or older.................. 30

K

Kaolin, nonmetal product.

Karst features, caves

lapies

sinkholes.

underground stream channels

\section{L}

La Chicaroma deposit, geologic occurrence...

La Paz, clastic deposits........... 48 . 49

Lapies

Laramide orogeny, relation to folds

50,51

.

travertine.

Las Moras, gravel.
Page

as $\mathrm{Trancas}$ formation, age $\ldots \ldots$
boudinage $\ldots \ldots \ldots$

cut by dike

description and distribution. . . . . . . . . . . 30-32

exposed in Jalpan syncline.............. 62

exposed in Pingüical anticline.......... $\quad 59$

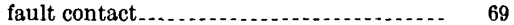

folds

fracture cleavage.................. 64, 66, 70

host rock ............. 80

relation to clastic deposits............... 49

relation to El Doctor limestone..... 31, 34, 39, 40

relation to El Morro fanglomerate....... 43

relation to undifferentiated volcanic rocks. 44,45

structure near San Pedro Escanela........ $\quad 70$

thrust faults...................... $66-67,68$

Lead mining . . . . . . .

Limestone, nonmetal product . . . . . . . . . ... 81

Llano de San Francisco sinkhole.... . . . . . . . . 70-71

Location . . . . . . . . . . . . 20

\section{M}

Mercury mining .......................... 78

Mesa de los Chilitos, volcanic rocks......... 45

Mesa de Ramirez, basalt . . . . . . .

red soil................ 51

Mesa del Hormiguero, basalt_...

Metals, distribution

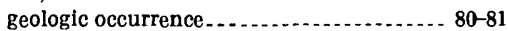

mining activity and production..... . . . 77-78

ore mineralogy and host rock. . . ........ $79-80$

Metamorphic rocks, Jurassic system or older . - 30

Mexcala, Río, type locality of Mexcala forma-

tion....................... 41

Mexcala formation, fault . . . . .

host rock . ................... 80

relation to undifferentiated volcanic rocks. $\quad 15$

See also Soyatal and Mexcala formations, undifferentiated.

Mexcala and Soyatal formations, relation to El Morro fanglomerate.......... 43

Milpilla, gravel terraces.

Mineral deposits, metals.................

nonmetals ........................ 81

Mining activity and production. . . . . . . . . . 77-78

Mining districts............................ 78

Mining methods, early................... 77-78

Montmorillonite, nonmetal product......... 81

\section{N}

Natural bridge. . . . . . . . . . . . . . . . . . . . . 75-76

Nonmetals. ........................... 81

Normal faults. . . . . .

O

Old erosion surfaces . . . . . . . . . . . . . 72-74

Opals... 44,81

Ore mineralogy

P

Palmas, caliche................ 50

El Morro fanglomerate................. 43

gravel................ 48

volcanic rocks. ................. 45 
Page

Peña Blanca, dike

faults.

Peña Blanca erosion surface

Peña de Bernal, porphyritic intrusive body -

Peñamiller, El Morro fanglomerate

foults.

fracture cleavage in Mexcala formation. 67 .

gravel terraces near.

sill.

volcanic rocks.

53

$66,67,69$

73,74

43

8,69

65

48

Pepino hills

Phyllite, pre-Las Trancas, host rock.........

Pinal de Amoles, caves. ........................ erosion forms.

lapies erosion.

mining district, activity and production $-78,70$

geologic occurrence of ore bodies...... 80

old erosion surface ......................... 72

outcrops of El Doctor limestone.......... $\quad 36$

Pingüical anticline . ....................... 59

porphyritic rocks......................... 53,54

red soll...................................

sinkholes. .............................. 70-71

stock .................. 56

tactite zone........................... 56

thrust faults........................... 66

underground stream channels............. 71

Ping üical anticline . .................... 57, 58-60

Placer gold . ................................ 80

Poder de Dios mine, porphyritic rocks......... $\quad 53$

Potholes........................................... 75,

Potrerillos, gravel .......................... 48

Pre-Las Trancas rocks............... 30

Puerto de Las Trancas, relation to type locality of Las Trancas formation ......

Puerto del Cielo, Pingüical anticline near.....

Puerto del Jabali, volcanic rocks................

Puerto de Roble, volcanic rocks.

\section{R}

Rainfall

$24-26,50$

Recent deposits of clastic material

50

Red soll....................................... 50-51

Rhyolite, host rock ........................ 80

Rhyolite dike............... 54-55

Rhyolite flows, opals. . ........................

Rhyolite intrusive body near Bernal, faults around.

Río Blanco, early gold and silver mining ......

fault

mining district

44

stocks

78,79

underground streams.

\section{$\mathrm{S}$}

San Antonio de la Cal, rhyolite.............. 55 San Lorenzo syncline...................... 57,60-62 San Martín Ajuchitlán, gold and silver mining...............................77,78 mine, tactite adjacent to intrusive rhyo. lite............................... ore body, geologic occurrence.

San Pat.10, caliche.

clastic deposits.

volcanic rocks.
San Pedro Escanela, faults and fracture cleavage........................... 69,70

Las Trancas formation . .................. $\quad 70$

Santa Clara, alluvial fan...................... $\quad 50$

Sedimentary rocks, Cretaceous system. . . .... 34-43

Jurassic system.......................... 30-34

Tertiary and Quaternary systems . ....... 47-52

Tertiary system......................... 43-44 Sierra Gorda summit region, oldest exposed erosion surface..................... 72

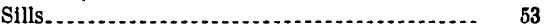

Silver chloride, ore mineral............... 79

Silver mining ............................. 77, 78, 79

Sinkholes................................... 70-71, 76

Soil. See Red soll

Soyatal, El Raizal fault. . ................... 68-68 mining district, activity and production.. 78,79 geologic occurrence of ore bodies........ $\quad 80$ rhyolite dike........................... 55

Soyatal formation, fault contact............... $\quad 69$

See also Soyatal and Mexcala formations, undifferentiated.

Soyatal and Mexcala formations, undifferentiated, absence of boudinage...... 63-64 age ...................................... 42-43 description and distribution.............. 40-42 exposed in Jalpan syncline.................. 62 fracture cleavage. . ........................ 64-66 old erosion surface ........................ 72, 73 relation to undifferentiated volcanic rocks. $\quad 44$ Stalactites..................................... 51 Stalagmites............................... 51

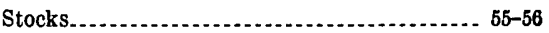
Stone houses. See Casas de piedra.

Stream piracy, subterranean.................. 75

Structure, boudinage........... 62-64

folds............................ 57-62

fracture cleavage.................... 64-66, 70

joints...................................... 68

thrust faults................................ $66-68$

\section{$\mathrm{T}$}

Tactite zone

Tancama, gravel........................... 48

Tarango formation........................ 48

Tejamantl, dike.............................. $\quad 63$

Temperature............................. 26

Terraces, gravel.............................. $48-49$

Tertiary and Quaternary systems, callche and red soil. ............................ 50-51 clastic deposits of late Cenozoic age....... 47-50 travertine............................... 51-52

Tertiary system, basalt...................... 47 El Morro fanglomerate................... 43-44

Thrust faults. .............................. 66-67

Tolimán, caliche.......................... $\quad 50$ clastic deposits........................... 48

El Chilar anticline..................... 57

E1 Morro fanglomerate................... 43 fault...................................... 69 mining district, activity and production.. 78,79 geologic occurrence of ore bodies........ 80 volcantc rocks.......................... 45 


\begin{tabular}{|c|c|}
\hline Page & Page \\
\hline $\begin{array}{l}\text { Topography... } \\
\text { Travertine... }\end{array}$ & $\begin{array}{l}\text { Volcanic rocks, undifferentiated, age..... } \\
\text { description and distribution }\end{array}$ \\
\hline$\dot{U}$ & $\mathbf{W}$ \\
\hline $\begin{array}{c}\text { Underground stream channels } \ldots \ldots \ldots \ldots \\
\mathrm{V}\end{array}$ & $\begin{array}{l}\text { Water supply. } \\
\text { White, D. E., quoted. }\end{array}$ \\
\hline Vegetation. & Z \\
\hline $\begin{array}{l}\text { Velasco, A. L., quoted... } 78 \\
\text { Vizarrón erosion surface... }\end{array}$ & $\begin{array}{l}\text { Zimapán, stock near. } \\
\text { Zinc mining. }\end{array}$ \\
\hline
\end{tabular}

